Prepared in cooperation with the West Virginia Department of Transportation, Division of Highways

\title{
Estimation of Flood-Frequency Discharges for Rural, Unregulated Streams in West Virginia
}

Scientific Investigations Report 2010-5033 



\section{Estimation of Flood-Frequency Discharges for Rural, Unregulated Streams in West Virginia}

By Jeffrey B. Wiley and John T. Atkins, Jr.

Prepared in cooperation with the West Virginia Department of Transportation, Division of Highways

Scientific Investigations Report 2010-5033 


\title{
U.S. Department of the Interior \\ KEN SALAZAR, Secretary \\ U.S. Geological Survey \\ Marcia K. McNutt, Director
}

\section{U.S. Geological Survey, Reston, Virginia: 2010}

\author{
For more information on the USGS — the Federal source for science about the Earth, its natural and living resources, \\ natural hazards, and the environment, visit http://www.usgs.gov or call 1-888-ASK-USGS \\ For an overview of USGS information products, including maps, imagery, and publications, \\ visit http://www.usgs.gov/pubprod \\ To order this and other USGS information products, visit http://store.usgs.gov
}

Any use of trade, product, or firm names is for descriptive purposes only and does not imply endorsement by the U.S. Government.

Although this report is in the public domain, permission must be secured from the individual copyright owners to reproduce any copyrighted materials contained within this report.

Suggested citation:

Wiley, J.B., and Atkins, J.T., Jr., 2010, Estimation of flood-frequency discharges for rural, unregulated streams in West Virginia: U.S. Geological Survey Scientific Investigations Report 2010-5033, 78 p. 


\section{Contents}

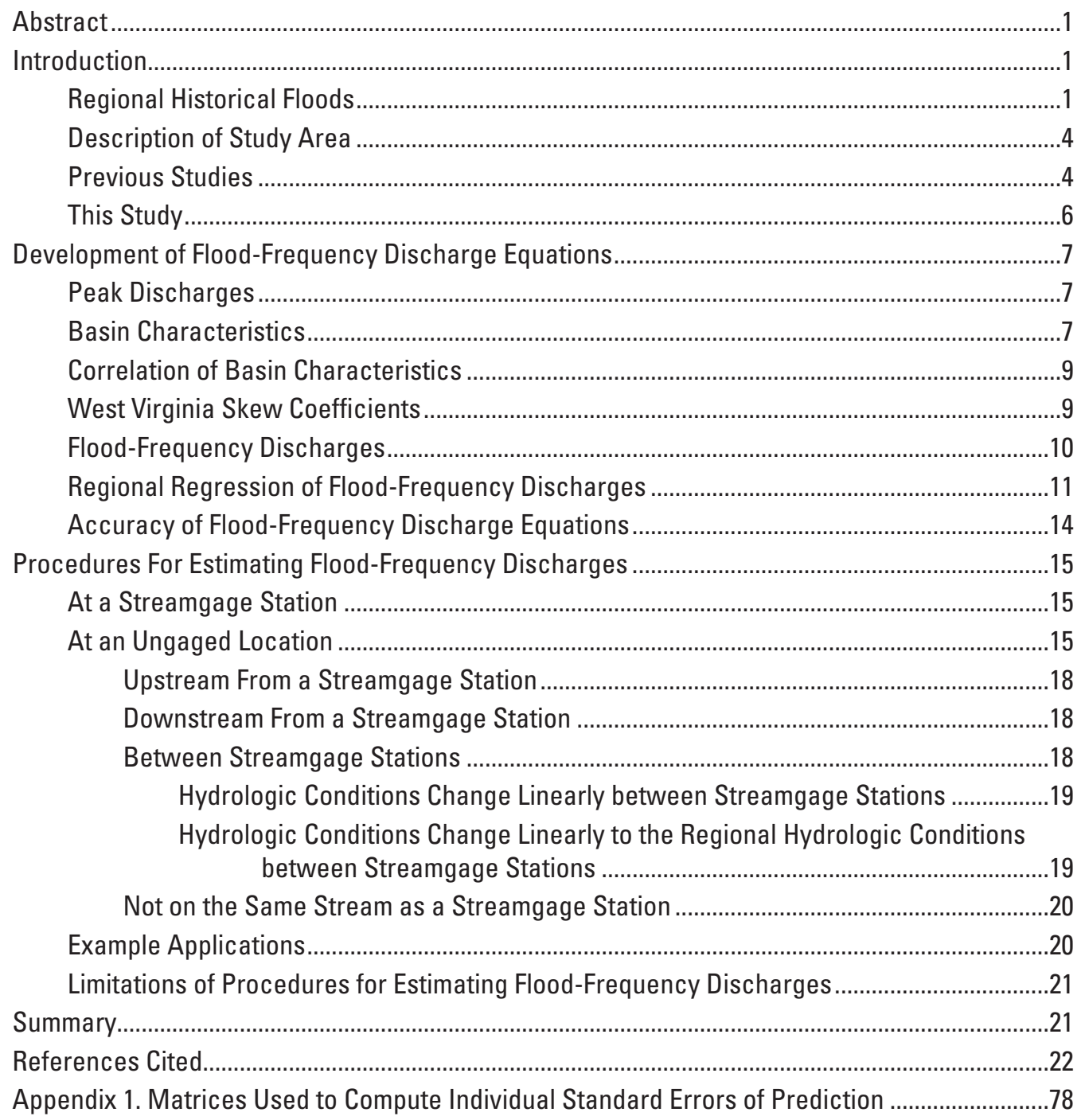




\section{Figures}

1-4. Map showing -

1. Selected streams used for identifying regional extent of historic floods in West Virginia .....

2. Appalachian Plateaus, Valley and Ridge, and Blue Ridge Physiographic Provinces, and Climatic Divide in West Virginia. .5

3. The 290 U.S. Geological Survey streamgage stations in West Virginia and adjacent states considered in the estimation of flood-frequency discharges in West Virginia. .8

4. The Eastern Panhandle, Central Mountains, and Western Plateaus Regions of West Virginia for which equations for estimation of flood frequency discharges were developed in this study.

5-7. Graph showing-

5. Range of differences of the individual standard errors of the prediction from the average prediction errors for the indicated drainage areas.

6. LOESS curves of the absolute difference between the 100-year flood discharges determined at streamgage stations and values estimated from the (1) drainage-area ratio method and (2) regional equations, in relation to the ratios of the drainage areas.

7. LOESS curves of the absolute difference between the 1.1- through 500-year flood discharges determined at streamgage stations and values estimated from the (1) drainage-area ratio method and (2) regional equations, in relation to the ratios of the drainage areas

\section{Tables}

1. Identification numbers, station numbers, streamgage-station names, and skew coefficients and statistics for the 290 U.S. Geological Survey streamgage stations on rural, unregulated streams in West Virginia and adjacent states.

2. Flood-frequency statistics and drainage areas for the 290 U.S. Geological Survey streamgage stations on rural, unregulated streams in West Virginia and adjacent states

3. Flood-frequency discharges for the 290 U.S. Geological Survey streamgage stations on rural, unregulated streams in West Virginia and adjacent states

4. Equations used to estimate selected flood-frequency discharges for streams in the Eastern Panhandle, Central Mountains, and Western Plateaus Regions of West Virginia

5. Description of the 88 pairs of U.S. Geological Survey streamgage stations in West Virginia and adjacent states that were evaluated to quantify "near" for application of the drainage-area ratio method in this study

6. Values of the exponent, and upstream and downstream limits of the drainagearea ratios used to quantify the definition of "near" for estimating selected flood-frequency discharges for ungaged locations in West Virginia... 


\section{Conversion Factors, Datums, Acronyms, and Abbreviations}

\begin{tabular}{|c|c|c|}
\hline Multiply & By & To obtain \\
\hline \multicolumn{3}{|c|}{ Length } \\
\hline inch (in.) & 2.54 & centimeter $(\mathrm{cm})$ \\
\hline foot $(\mathrm{ft})$ & 0.3048 & $\operatorname{meter}(\mathrm{m})$ \\
\hline mile (mi) & 1.609 & kilometer $(\mathrm{km})$ \\
\hline \multicolumn{3}{|c|}{ Area } \\
\hline square mile $\left(\mathrm{mi}^{2}\right)$ & 2.590 & square kilometer $\left(\mathrm{km}^{2}\right)$ \\
\hline \multicolumn{3}{|c|}{ Flow rate } \\
\hline cubic foot per second $\left(\mathrm{ft}^{3} / \mathrm{s}\right)$ & 0.02832 & cubic meter per second $\left(\mathrm{m}^{3} / \mathrm{s}\right)$ \\
\hline $\begin{array}{l}\text { cubic foot per second per square } \\
\text { mile }\left[\left(\mathrm{ft}^{3} / \mathrm{s}\right) / \mathrm{mi}^{2}\right]\end{array}$ & 0.01093 & $\begin{array}{l}\text { cubic meter per second per square } \\
\text { kilometer }\left[\left(\mathrm{m}^{3} / \mathrm{s}\right) / \mathrm{km}^{2}\right]\end{array}$ \\
\hline
\end{tabular}

Vertical coordinate information is referenced to the North American Vertical Datum of 1988 (NAVD 88).

Horizontal coordinate information is referenced to the North American Datum of 1983 (NAD 83). Altitude, as used in this report, refers to distance above the vertical datum.

\section{Acronyms}

GLSNet USGS software for computing generalized least-square regression

LOESS Locally weighted regression

PeakF0 USGS software for computing flood-frequency discharges

S-PLUS Commercially available software for computing statistics

USGS U.S. Geological Survey

SWSTAT USGS software for computing surface-water statistics

\section{Abbreviations}

AOP Annual-occurrence probability

$\mathbf{A}_{\mathbf{u}}$ Drainage area at the location of the unknown flood-frequency discharge

$\mathbf{A}_{\boldsymbol{K}}$ Drainage area at the location of the known flood-frequency discharge

$\mathbf{A}_{\text {us }}$ Drainage area at the upstream location

$\mathbf{A}_{\mathrm{DS}}$ Drainage area at the downstream location

AOP Annual-occurrence probability

DRNAREA Drainage area

EX Exponent for drainage-area ratios 
$\mathbf{E}_{\mathrm{Y}}$ Equivalent years of record

K Frequency factor

MSE Mean-square error

$\mathbf{N}$ Number of years of peak-discharge record

0 Discharge

$\mathbf{0}_{\mathrm{DS}} \quad$ Flood-frequency discharge at the downstream location

$\mathbf{0}_{\mathbf{K}} \quad$ Known flood-frequency discharge

$\mathbf{0}_{\mathrm{KE}}$ Regional equation evaluated at the location of the known flood-frequency discharge

$\mathbf{0}_{\mathbf{r}}$ Flood-frequency discharge determined from the appropriate regional equation

$\mathbf{0}_{\text {s }}$ Flood-frequency discharge determined from systematic and historical record

$\mathbf{0}_{\mathbf{u}}$ Unknown flood-frequency discharge

$\mathbf{0}_{\mathrm{UE}}$ Regional equation evaluated at the location of the unknown flood-frequency discharge

$\mathbf{0}_{\text {us }}$ Flood-frequency discharge at the upstream location

$\mathbf{0}_{w}$ Discharge weighted by number of years of peak-discharge record at the gaging station and equivalent years of record for the appropriate regional equation

Q(n) Discharge for the n-year recurrence interval

$\mathbf{R}_{\mathrm{DS}}$ Downstream limit of the ratio of drainage areas

$\mathbf{R}_{\mathbf{U} / \mathbf{K}}$ Ratio of the drainage area at the location of the unknown flood-frequency discharge to the drainage area at the location of the known flood-frequency discharge

$\mathbf{R}_{\text {us }}$ Upstream limit of the ratio of drainage areas

$\mathbf{S}_{\mathbf{p}}$ Standard deviation of the $\log _{10}$-transformed annual peak discharges

X $\log _{10}$-transformed annual peak discharges

$\mathbf{X}_{\text {mean }}$ Mean of the $\log _{10}$-transformed annual peak discharges 


\title{
Estimation of Flood-Frequency Discharges for Rural, Unregulated Streams in West Virginia
}

\author{
By Jeffrey B. Wiley And John T. Atkins, Jr.
}

\section{Abstract}

Flood-frequency discharges were determined for 290 streamgage stations having a minimum of 9 years of record in West Virginia and surrounding states through the 2006 or 2007 water year. No trend was determined in the annual peaks used to calculate the flood-frequency discharges.

Multiple and simple least-squares regression equations for the 100-year (1-percent annual-occurrence probability) flood discharge with independent variables that describe the basin characteristics were developed for 290 streamgage stations in West Virginia and adjacent states. The regression residuals for the models were evaluated and used to define three regions of the State, designated as Eastern Panhandle, Central Mountains, and Western Plateaus. Exploratory data analysis procedures identified 44 streamgage stations that were excluded from the development of regression equations representative of rural, unregulated streams in West Virginia. Regional equations for the 1.1-, 1.5-, 2-, 5-, 10-, 25-, 50-, 100-, 200-, and 500-year flood discharges were determined by generalized least-squares regression using data from the remaining 246 streamgage stations. Drainage area was the only significant independent variable determined for all equations in all regions.

Procedures developed to estimate flood-frequency discharges on ungaged streams were based on (1) regional equations and (2) drainage-area ratios between gaged and ungaged locations on the same stream. The procedures are applicable only to rural, unregulated streams within the boundaries of West Virginia that have drainage areas within the limits of the stations used to develop the regional equations (from 0.21 to 1,461 square miles in the Eastern Panhandle, from 0.10 to 1,619 square miles in the Central Mountains, and from 0.13 to 1,516 square miles in the Western Plateaus). The accuracy of the equations is quantified by measuring the average prediction error (from 21.7 to 56.3 percent) and equivalent years of record (from 2.0 to 70.9 years).

\section{Introduction}

Many engineering projects are built within or adjacent to flood-prone areas. Information on past flooding and estimates of the magnitude and frequency of potential future floods are critical to the safe and economical design of hydraulic structures such as bridges, culverts, dams, flood dikes, and levees.

\section{Regional Historical Floods}

Before 1930, neither floods nor streamflow in West Virginia were systematically documented. Since 1930, data on regional flooding has been collected as part of the operation of a statewide streamgaging network supported by State and Federal funding. Local floods in small, ungaged watersheds remain only sparsely quantified. Major regional floods affecting parts of West Virginia occurred in 1844, 1877, 1878, 1888, 1889, 1912, 1918, 1932, 1936, 1949, 1963, 1967, 1977, 1984, 1985 , and 1996. For floods prior to 1930, the regional extent is not defined, but rivers other than those identified in West Virginia may have been affected. Locations of selected West Virginia streams are shown in figure 1. A list of flood dates with a brief description of the flood and the report that documents the flood follows.

- July 1844: Flooding on the Cheat River was documented by Speer and Gamble (1965, p. 148). This flood was about equal in magnitude to those in July 1888 and May 1996.

- November 1877: Flooding on the South Branch Potomac River was documented by Tice (1968, p. 488, 490). This flood was about equal in magnitude to those in March 1936 and September 1996.

- September 1878: Flooding on the New River was documented by Speer and Gamble (1965, p. 284-288). 


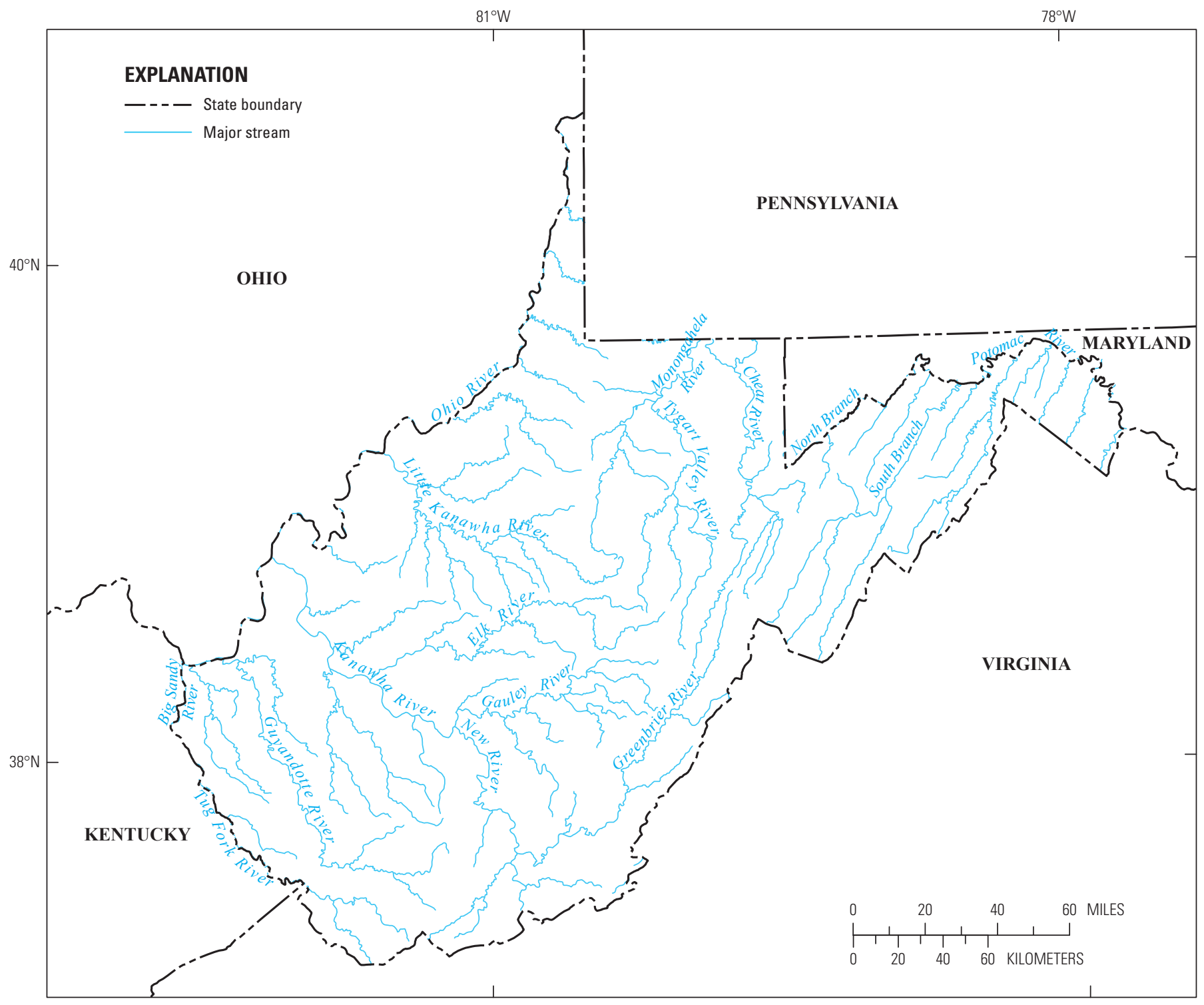

Base from U.S. Geological Survey 1:100,000 digital line graphics.

Universal Transverse Mercator projection, zone 17, NAD 83.

Figure 1. Selected streams used for identifying regional extent of historic floods in West Virginia. 
- July 1888: Flooding on the Monongahela River was documented by Speer and Gamble (1965, p. 121, 138, 146-149). This flood was about equal in magnitude to those in July 1844 on the Cheat River and May 1996 on the Cheat and upper Monongahela Rivers.

- May-June 1889: Flooding on the North Branch Potomac River was documented by Tice (1968, p. 480, 490, 494, 497). This flood was about equal in magnitude to those in March 1936 and September 1996.

- July 1912: Flooding on the Tygart Valley River was documented by Speer and Gamble (1965, p. 118, 121, 127-128).

- March 1918: Flooding on the Greenbrier and Gauley Rivers was documented by Speer and Gamble (1965, p. 298, 310).

- February 1932: Flooding on the Tygart Valley, Greenbrier, and Gauley Rivers was documented by Speer and Gamble (1965, p. 119, 121, 129, 295, 298, 304, 307, 310).

- March 1936: Flooding was documented on the Potomac and Cheat Rivers. This flood, which was documented by Grover (1937) as having a regional extent including the upper Ohio, Potomac, and James Rivers (the James River in Virginia), was caused by four separate cyclonic storms passing over the northeastern United States, resulting in multiple peak discharges and superposition of later peak discharges on earlier peak discharges. This flood was about equal in magnitude to those in November 1877 on the South Branch Potomac River, May through June 1889 on the North Branch Potomac River, and September 1996 on the upper Potomac River (both North and South Branch).

- June 1949: Flooding on the South Branch Potomac River was documented by Tice (1968, p. 483-488).

- March 1963: Flooding was documented on the Big Sandy (including the Tug Fork in West Virginia), Guyandotte, Little Kanawha, Cheat, and Greenbrier Rivers. This flood, which was documented by Barnes (1964) as having affected the western slopes of the Appalachian Mountains from Alabama to West Virginia, was caused by three separate frontal storms in which rain fell on a snowpack and was followed by two additional storms.

- March 1967: Flooding was documented on the Kanawha and Monongahela Rivers. This flood was caused by 4 to 5 in. of rainfall over 3 days, augmented by runoff from melting snow (U.S. Geological Survey, 1991).
- April 1977: Flooding was documented on the Tug Fork and Guyandotte Rivers. This flood was documented by Runner (1979) and Runner and Chin (1980) as having affected northeastern Tennessee, southwestern Virginia, eastern Kentucky, and southern West Virginia. This flood resulted from a frontal storm that moved southeastward through the region, became stationary, then moved slowly northwestward drawing a warm moist maritime airmass from the Gulf of Mexico and combining to produce heavy rainfall. The highest peak discharges ever recorded on the Tug Fork and Guyandotte Rivers resulted from this storm.

- May 1984: Flooding was documented on the Tug Fork and Guyandotte Rivers (U.S. Geological Survey, 1991).

- November 1985: Flooding was documented on the Monongahela, Potomac, upper Little Kanawha, upper Elk, and upper Greenbrier Rivers. This flood was documented by Lescinsky (1987) and Carpenter (1990) as having affected eastern West Virginia, western and northern Virginia, southwestern Pennsylvania, and western Maryland. This flood resulted from a complex sequence of meteorological events. Hurricane Juan moved from the Gulf of Mexico through southern Mississippi, ultimately causing precipitation as far north as Michigan and generating less than 2 in. of rainfall in West Virginia. This rainfall was caused by a second low pressure system that developed from the hurricane remnants. The low pressure developed near the Tennessee-North Carolina border and traveled rapidly eastward to the Atlantic Ocean. A third low pressure system moved from the Gulf of Mexico into the Florida panhandle then moved slowly up the east coast of the United States, resulting in additional rainfall in West Virginia of up to $9 \mathrm{in}$. The highest peak discharges ever recorded on the upper Monongahela and Potomac Rivers resulted from this flood.

- January 1996: About 2 in. of rain fell on a 3 to $4 \mathrm{ft}$ snowpack, resulting in flooding in the upper Potomac, upper Cheat, upper Elk, and Greenbrier Rivers.

- May 1996: A frontal storm caused flooding on the Cheat and upper Monongahela Rivers that was about equal in magnitude to flooding on the Cheat River in July 1844 and July 1888.

- September 1996: Tropical storm Fran caused regional flooding on the upper Potomac River. This flood was about equal in magnitude to that in November 1877 on the South Branch Potomac River, to that in May through June 1889 on the North Branch Potomac River, and to that in March 1936 on the upper Potomac River. 
Estimation of Flood-Frequency Discharges for Rural, Unregulated Streams in West Virginia

\section{Description of Study Area}

West Virginia can be differentiated into three physiographic provinces, the Appalachian Plateaus, Valley and Ridge, and Blue Ridge (Fenneman, 1938) (fig. 2). The movement of air masses across the State allows identification of two climatic regions, separated by a line defined as the Climatic Divide (Wiley, 2008) (fig. 1).

Generally, the part of the State west of the Climatic Divide is in the Appalachian Plateaus Physiographic Province, where altitudes range from about 2,500 to 4,861 ft (NAVD88) at Spruce Knob along the Climatic Divide to about 550 to $650 \mathrm{ft}$ along the Ohio River. The part of West Virginia east of the Climatic Divide is in the Valley and Ridge Physiographic Province, except for the extreme eastern tip of the State, which is in the Blue Ridge Physiographic Province. Altitudes decrease eastward from the Climatic Divide to $274 \mathrm{ft}$ at Harpers Ferry in the Eastern Panhandle (U.S. Geological Survey, 1990, 2006; National Oceanic and Atmospheric Administration, 2006a).

The Appalachian Plateaus Physiographic Province consists of consolidated, mostly noncarbonate sedimentary rocks that have a gentle slope from southeast to northwest near the Climatic Divide and are nearly flat-lying along the Ohio River. One exception is in the northeastern area of the province (west of the Climatic Divide), where the rocks are gently folded and some carbonate rock crops out (Fenneman, 1938). The rocks in the Appalachian Plateaus Physiographic Province have been eroded to form steep hills and deeply incised valleys; drainage patterns are dendritic.

The Valley and Ridge Physiographic Province in West Virginia consists of consolidated carbonate and noncarbonate sedimentary rocks that are folded sharply and extensively faulted (Fenneman, 1938). Northeast-trending valleys and ridges parallel the Climatic Divide; drainage patterns are trellis.

The Blue Ridge Physiographic Province within West Virginia consists predominantly of metamorphosed sandstone and shale (Fenneman, 1938). The province has high relief between mountains and wide valleys that parallel the Climatic Divide.

The climate of West Virginia is primarily continental, with mild summers and cold winters. Major weather systems generally approach from the west and southwest, although polar continental air masses of cold, dry air that approach from the north and northwest are not unusual. Air masses from the Atlantic Ocean sometimes affect the area east of the Climatic Divide and less frequently affect the area west of the Climatic Divide. Generally, tropical continental masses of hot, dry air from the southwest affect the climate west of the Climatic Divide. Tropical maritime masses of warm, moist air from the Gulf of Mexico affect the climate east of the Climatic Divide more than west of the Climatic Divide. Evaporation from local and upwind land surfaces, lakes, and reservoirs also provides a source of moisture that affects the climate of the State (U.S. Geological Survey, 1991; National Oceanic and Atmospheric Administration, 2006a).
Annual precipitation averages about 42 to 45 in. statewide with about 60 percent received from March through August. July is the wettest month, and September through November are the driest. Annual average precipitation in the State generally decreases northwestward from about 50 to 60 in. along the Climatic Divide to about 40 in. along the Ohio River, and increases from about 30 to $35 \mathrm{in}$. east of the Climatic Divide to about 40 in. in the extreme eastern tip of the State. Greater precipitation along and west of the Climatic Divide is a consequence of the higher elevations along the Divide and the general movement of weather systems approaching from the west and southwest. Annual average snowfall follows the general pattern of annual average precipitation, decreasing northwestward from about 36 to $100 \mathrm{in}$. along the Climatic Divide to about 20 to 30 in. along the Ohio River. Annual average snowfall ranges from 24 to 36 in. east of the Climatic Divide (U.S. Geological Survey, 1991; Natural Resources Conservation Service, 2006; National Oceanic and Atmospheric Administration, 2006a, 2006b).

Flooding across large drainage areas results from regional climatic events like frontal systems in winter and early spring, rainfall on snowpack in early spring, and tropical cyclones (hurricanes and tropical storms) in late summer or early fall. Generally, the most severe flooding across small drainage areas results from local intense thunderstorms in late spring through summer (Doll and others, 1963).

\section{Previous Studies}

Flood-frequency studies completed by Wiley and others $(2000,2002)$ used data for peak discharges from 267 rural, unregulated streamgage stations in West Virginia and adjacent states. Simple and multiple least-squares regression models were used to determine three regions in the State and to develop initial estimating equations with drainage area as the only significant independent variable. The final estimating equations were determined for the 1.1-, 1.2-, 1.3-, 1.4-, 1.5-, 1.6-, 1.7-, 1.8-, 1.9-, 2-, 2.5-, 3-, 5-, 10-, 25-, 50-, 100-, $200-$, and 500-year flood discharges using a generalized leastsquares regression model (Stedinger and Tasker, 1985; Tasker and Stedinger, 1989).

New procedures for transferring the flood-frequency discharges determined by Wiley and others $(2000,2002)$ to ungaged locations were presented by Wiley (2008, Appendix 1). These methods incorporated a comparison of discharge estimates determined using drainage-area ratios to discharge estimates determined by application of the flood-frequency equations. This current study repeats that analysis and supersedes the results presented in Wiley (2008, Appendix 1).

Atkins and others (2009) determined generalized skew coefficients applicable to West Virginia (WV skew) for use in determining flood-frequency discharges at streamgage stations. The WV skew coefficients supersede the United States skew coefficients (U.S. skew) determined by the Interagency Advisory Committee on Water Data (1982). Analysis of 


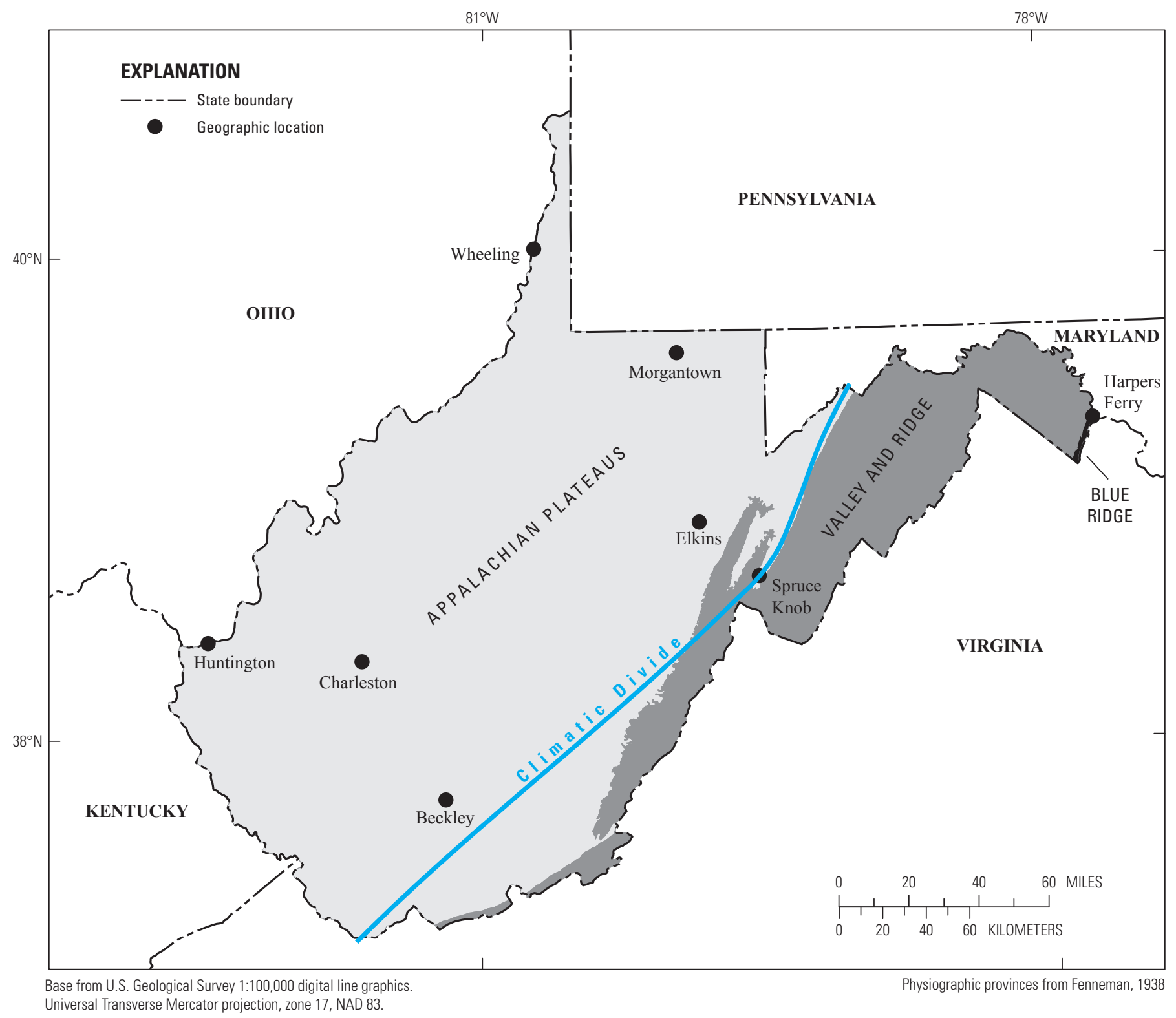

Figure 2. Appalachian Plateaus, Valley and Ridge, and Blue Ridge Physiographic Provinces, and Climatic Divide in West Virginia. 
Estimation of Flood-Frequency Discharges for Rural, Unregulated Streams in West Virginia

discharges at 147 rural, unregulated streams in West Virginia and adjacent states with streamgage stations followed guidelines established by the Interagency Advisory Committee on Water Data (1982), except that streamgage stations having 50 or more years of record were used instead of those with the recommended 25 years of record. The increased record length of 50 years was determined to be statistically significant when compared to the recommended 25 years. The generalizedskew analysis considered contouring, averaging, and regression of station skews; the best method was determined to be that with the smallest mean-square error (MSE). The contouring of station skews was found to be the best method for determining generalized skew for West Virginia, with a MSE of 0.2174 (Atkins and others, 2009). The MSE of 0.2174 is a significant improvement (28 percent reduction) over the MSE of 0.3025 for the U.S. skew, presented by the Interagency Advisory Committee on Water Data (1982).

Flood-frequency studies completed by Frye and Runner $(1969,1970,1971)$ and Runner $(1980 a$ and b) for West Virginia lacked data on peak discharges at streamgage stations having drainage areas less than $50 \mathrm{mi}^{2}$. These studies found that the lack of data for small drainage areas could be overcome by (1) not using the flood-frequency estimating methods for small drainage areas, (2) limiting the flood-frequency discharge estimates to small recurrence intervals, (3) increasing the record lengths for small drainages by using a rainfallrunoff model, or (4) using a composite analysis of long-term data (primarily stations with a minimum of 40 years of record) with an analysis of long-term data combined with short-term data for small drainage areas.

Frye and Runner (1969) estimated flood-frequency discharges for rural, unregulated streams in West Virginia by using equations presented in U.S. Geological Survey Water Supply Papers 1672 (Tice, 1968) and 1675 (Speer and Gamble, 1965). The nationwide flood-frequency discharge equations in these publications were developed for regional or major river basins. The authors suggested that the equations only be used for drainage areas greater than $50 \mathrm{mi}^{2}$ in the Ohio River Basin and greater than $30 \mathrm{mi}^{2}$ in the Potomac River Basin.

Frye and Runner (1970) presented a method for estimating flood-frequency discharges using an analytical technique similar to that proposed by Benson (1962). Peak-discharge data from streamgage stations on rural, unregulated streams in West Virginia with a minimum of 10 years of record were analyzed. The authors suggested that the analytical techniques be used only for drainage areas greater than $50 \mathrm{mi}^{2}$ because adequate data were not available.

Frye and Runner (1971) presented a method for estimating the 2-, 5-, and 10-year flood discharges for rural, unregulated streams in the Ohio River Basin of West Virginia. Data from a network of small streams with an average record length of 6 years were correlated with long-term data from streamgage stations to estimate additional years of peak discharges. The equations were applicable only to streams with drainage areas between 1 and $50 \mathrm{mi}^{2}$.
Runner (1980a) presented equations for estimating the 2-, 5-, 10-, 25-, 50-, 100-, and 500-year flood discharges for rural, unregulated streams in West Virginia. The estimating equations were used only for drainage areas of 0.3 to $2,000 \mathrm{mi}^{2}$. The flood-frequency discharges in this study were made using methods recommended by the Interagency Advisory Committee on Water Data (1976), including adjustments to stationfrequency determinations by applying weighted regional and station skews. The peak-discharge data from 170 streamgage stations included data from Maryland and Virginia. Records of peak discharges for 15 stations with small drainage areas (ranging from 1.8 to $12.2 \mathrm{mi}^{2}$ ) were synthesized to greater than 40 years of record (Runner, 1980b) by use of a rainfall-runoff model developed by Dawdy and others (1972). On the basis of regression analyses using 12 basin characteristics as independent variables, regional flood-frequency discharge equations were developed separately for stations with more than 40 years of record (including 15 small drainage-area streamgage stations for which at least 40 -year records were estimated) and for all 170 stations. Three regions were delineated using an analysis of the regression residuals, and drainage area was determined to be the only statistically significant independent variable. A composite of the equations for stations with greater than 40 years of record and all 170 streamgage stations was determined.

\section{This Study}

To provide flood-related information and estimates needed for the design of structures that will meet existing or proposed safety standards, yet not incur excessive costs because of overdesign, the U.S. Geological Survey (USGS), in cooperation with the West Virginia Department of Transportation, Division of Highways, revised previously developed equations for estimating the magnitude and frequency of flood discharges on rural, unregulated streams in West Virginia. The results of this study supersede those published by Wiley and others $(2000,2002)$.

This report presents newly revised equations for estimating the discharges of the 1.1-, 1.5-, 2-, 5-, 10-, 25-, 50-, 100-, 200-, and 500-year recurrence interval floods (flood-frequency discharges) on rural, unregulated streams in West Virginia. A flood frequency is the reciprocal of the annual-occurrence probability (AOP), in percent, where the 100-year flood frequency is equal to the 1-percent AOP. This report documents the information used to estimate flood-frequency discharges and includes a list of regional floods in West Virginia; a discussion of climatic conditions affecting flooding; a presentation of results from previous studies; and an inventory of data sources containing peak discharges, basin characteristics, and skew coefficients. The statistical methods are described, including an accounting of error, which provides project designers with the associated uncertainty of flood discharge estimates determined from applying flood-frequency discharge equations to West Virginia streams. 


\section{Development of Flood-Frequency Discharge Equations}

Annual peak discharge data, basin characteristics data, and generalized West Virginia skew coefficients for 290 streamgages on rural, unregulated streams in West Virginia and adjacent states were analyzed to determine regional equations to be used to estimate the magnitude of flood discharges for selected recurrence intervals. Basin characteristics, generalized West Virginia skew coefficients, and flood-frequency discharges for streamgage stations in adjacent states developed for this study do not supersede values used by adjacent states. The equations for the 100-year recurrence interval (1-percent AOP) flood discharges were regionalized by plotting the areal distribution of residuals determined by use of multiple and simple least-squares regression models. Independent variables describe basin characteristics (such as drainage area, mean annual precipitation, and percent forest cover) for each station location. Areal distributions of residual plots from regressions of the 100-year discharges were used to select stations in adjacent states to represent flood discharges expected in West Virginia and to determine regional boundaries. The initial regional equations for the selected recurrence intervals were derived with the use of multiple and simple least-square regression models and by determining the significance of independent variables. The final regional equations were derived with the use of a generalized least-square regression model and independent variables from the initial regional equations.

\section{Peak Discharges}

Annual peak discharges at 290 streamgage stations on rural, unregulated streams with a minimum of 9 years of record through the 2007 water year (the period beginning October 1 of the previous year through September 30 of the indicated year) in West Virginia and through the 2006 (2007 for some stations in Maryland) water year for stations in adjacent states were available for this study (fig. 3; table 1, at end of this report). Guidelines established by the Interagency Advisory Committee on Water Data (1982) required that streamgage used in the analysis have a minimum of 10 years of record, but stations with 9 years of record were accepted because the addition of six stations with drainage areas less than $30 \mathrm{mi}^{2}$ was considered more beneficial to this study than adhering to the 10-year guideline. Annual-peakdischarge data are maintained in the U.S. Geological Survey's "Peak File" database available on the World Wide Web from the USGS United States NWIS-W Data Retrieval site (http://waterdata.usgs.gov/).

Peak discharges at the streamgage station Cheat River at Rowlesburg, identification number (ID) 121 in fig. 3 and streamgage station number (streamgage) 03070000 in table 1, are from a combination of records that include and exclude flow from the tributary stream Saltlick Creek. Peak-discharge data collected at Rowlesburg prior to the flood of November 5, 1985, include flow from Saltlick Creek for a drainage area of $974 \mathrm{mi}^{2}$. Peak-discharge data collected at Rowlesburg from November 6, 1985, through September 30, 1996, exclude flow from Saltlick Creek for a drainage area of $939 \mathrm{mi}^{2}$. Streamgage station ratings (relations between stream stage and discharge) were difficult to define accurately after November 5, 1985, because they were affected by scour throughout the range of stage. Peak discharges were not adjusted for the 4-percent difference in drainage area (typically necessary when records are combined) because the rating definition difficulties resulted in peak discharges with much greater than 4 percent uncertainties.

Peak discharges at the streamgage station Right Fork Holly River at Guardian (ID 229 and streamgage 03195100) for the 1979 to 1982 water years, and peak discharges at the station Left Fork Holly River near Replete (ID 230 and streamgage 03195250) for the 1979 to 1982 and 1987 to 2007 water years were provided by the U.S. Army Corps of Engineers, Huntington District (Phillip E. Anderson, oral and written commun., 1997 and 1998; Charlotte L. Hazelett, written commun., 2007).

Peak discharges at the streamgage station Fernow Watershed Number Four near Hendricks (ID 113 and streamgage 03067100) for the 1952 to 2006 water years were provided by the U.S. Forest Service, Fernow Experimental Forest (Frederica Wood, written commun., 2006 and 2007). No data were available for the 2007 water year at the time of this study.

Peak discharge records for the streamgage station Elk River below Webster Springs (ID 227 and streamgage 03194700) were lengthened using records for the station Elk River at Centralia (ID 228 and streamgage 03195000). Peak discharges at the station Twelvepole Creek below Wayne (ID 266 and streamgage 03207020) were lengthened using records for the station Twelvepole Creek at Wayne (ID 265 and streamgage 03207000). Peak discharges at the station Tug Fork at Kermit (ID 285 and streamgage 03214500) were lengthened using records for Tug Fork near Kermit (ID 284 and streamgage 03214000). Peak discharges at the station New River at Fayette (ID 207 and streamgage 03186000) were lengthened using records for New River at Caperton (ID 206 and streamgage 03185500); and peak discharges at the station Cheat River near Pisgah (ID 123 and streamgage 03071000) were lengthened using records for Cheat River near Morgantown (ID 124 and streamgage 03071500). Records were lengthened by estimating discharges using drainage-area ratios; the stations used to lengthen records were not considered in the regression analysis.

\section{Basin Characteristics}

Characteristics of the basins draining to the 290 streamgage stations on rural, unregulated streams in West Virginia and adjacent states (Paybins, 2008) were available for use as independent variables in the regression analysis. 


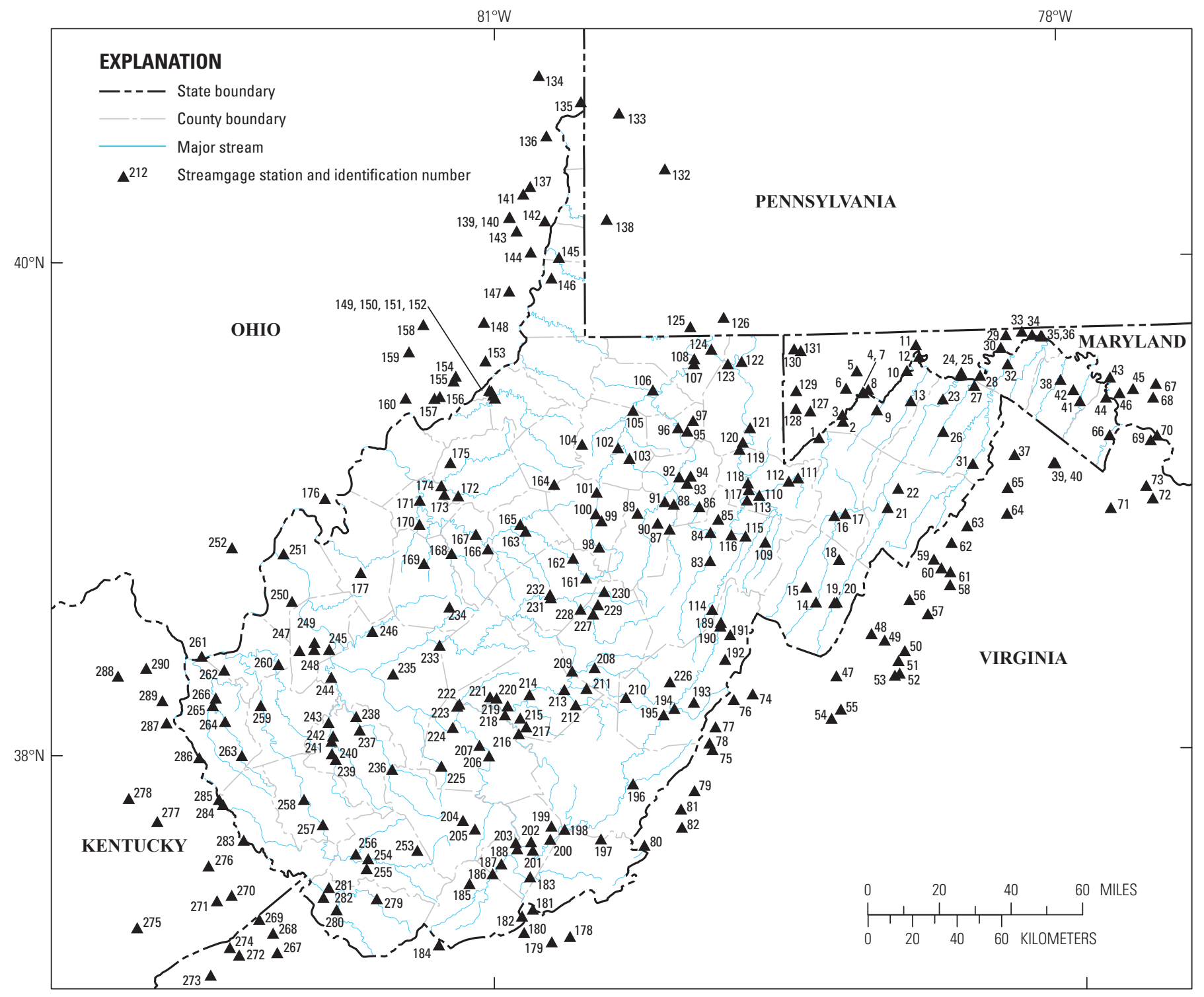

Base from U.S. Geological Survey 1:100,000 digital line graphics for state boundaries and streams and from the West Virginia Department of Environmental Protection 1:24,000 digital data for county boundaries. Universal Transverse Mercator projection, zone 17, NAD 83.

Figure 3. The 290 U.S. Geological Survey streamgage stations in West Virginia and adjacent states considered in the estimation of flood-frequency discharges in West Virginia. (Identification numbers are cross-references with streamgage-station names and numbers in table 1.) 
The 36 basin characteristics evaluated for use in this study are the following: drainage area (DRNAREA), in $\mathrm{mi}^{2}$ (Mathes, 1977; Wilson, 1979; Mathes and others, 1982; Preston and Mathes, 1984; Stewart and Mathes, 1995; Wiley, 1997; Wiley and others, 2007); latitude of the basin centroid, in decimal degrees; longitude of the basin centroid, in decimal degrees; basin perimeter, in mi; basin slope, in $\mathrm{ft} / \mathrm{mi}$; basin relief, in $\mathrm{ft}$; basin orientation, in degrees; channel length, in mi; valley length, in mi; channel slope, in ft/mi; stream length, in mi; mean basin elevation, in ft; 24-hour 2-year rainfall, in inches; annual precipitation, in inches; January minimum temperature, in degrees Fahrenheit; annual snow depth, in inches; forest cover, in percent; grassland cover, in percent; barren land cover, in percent; urban land cover, in percent; wetland cover, in percent; open-water cover, in percent; agriculture cover, in percent; impervious cover, in percent; basin width, in mi; shape factor, dimensionless; elongation ratio, dimensionless; rotundity of basin, dimensionless; compactness ratio, dimensionless; relative relief, in $\mathrm{ft} / \mathrm{mi}$; sinuosity ratio, dimensionless; stream density, in $\mathrm{mi} / \mathrm{mi}^{2}$; channel maintenance, in $\mathrm{mi}^{2} / \mathrm{mi}$; slope proportion, dimensionless; ruggedness number, in $\mathrm{ft} / \mathrm{mi}$; and slope ratio, dimensionless.

\section{Correlation of Basin Characteristics}

The basin characteristics were $\log _{10}$ transformed and evaluated for linear correlation by using a Pearson coefficient, or Pearson's r (Helsel and Hirsch, 2002). The numeral one was added to values of grassland cover, barren land cover, urban land cover, wetland cover, open-water cover, agriculture cover, and impervious cover to ensure that values were greater than zero for $\log _{10}$ transformation. To decrease values for regression analysis, 77 was subtracted from longitude of the basin centroid, and 37 was subtracted from latitude of the basin centroid.

Basin characteristics were considered highly correlated where the absolute value of the Pearson coefficient was greater than or equal to 0.80 . The following characteristics were highly correlated within each group: drainage area, basin perimeter, channel length, valley length, basin width, stream length, compactness ratio, and slope proportion; channel slope, relative relief, and slope ratio; shape factor, elongation ratio, and rotundity of basin; basin relief and ruggedness number; valley length and basin relief; and urban land cover and impervious cover.

The Pearson coefficient was equal to the numeral one (singularity) for some combinations of basin characteristics including stream density and channel maintenance; shape factor, elongation ratio, and rotundity of basin; drainage area, basin width, shape factor, and rotundity of basin; and stream length, compactness ratio, relative relief, stream density, and ruggedness number. The characteristics elongation ratio, rotundity of basin, channel maintenance, and basin width were removed from consideration for regression because of singularity.

The number of basin characteristics considered for regression was reduced from 36 to 32 with the removal of the characteristics because of singularity. Additional characteristics having singularity were removed if they became significant in the regression analysis.

\section{West Virginia Skew Coefficients}

Atkins and others (2009) determined generalized skew coefficients applicable to West Virginia, the WV skew, to supersede the U.S. skew presented by the Interagency Advisory Committee on Water Data (1982) (table 1, at the end of this report). The generalized skew coefficient is a regional measure (of individual streamgage-station skews) of the fitness of annual-peak discharges to a Pearson Type III probability curve. The WV skew coefficients used in this current study do not supersede values used for studies in adjacent states but are applicable only to analyses in West Virginia. The difference between the WV- and U.S.-skew coefficients (WV skew minus U.S. skew) ranged from -0.493, unitless, for Brier Creek at Fanrock (ID 255 and streamgage 03202480) to 0.491, unitless, for Dry Fork at Hendricks (ID 110 and streamgage 03065000).

A direct relation was not observed between the difference between the WV- and U.S.-skew coefficients and the difference between the flood-frequency discharge calculations made using the WV- and U.S.-skew coefficients. (Skew coefficients are weighted and adjusted using systematic years of record, systematic skews, low- and high-outlier criterion, and historic years to determine flood frequencies.) The 100-year flood discharges determined in this study using the WV skew were compared to the 100-year flood discharges calculated using the U.S. skew. The differences in the 100-year flood discharges (discharge using WV skew minus discharge using U.S. skew, divided by discharge using WV skew, times 100) ranged from -23.8 percent for Marsh Fork at Maben (ID 253 and streamgage 03202245$)$ to 13.3 percent for Job Run near Wymer (ID 109 and streamgage 03063950). An area of large negative differences was observed for the headwaters of the Coal, Guyandotte, and Tug Fork Rivers near the southern border of the State, and an area of large positive differences was observed for the headwaters of the South Branch Potomac River near the eastern border of the State. The difference for Brier Creek at Fanrock (ID 255 and streamgage 03202480) is -14.3 percent $(-0.493$, unitless, difference in skews discussed above), and the difference for Dry Fork at Hendricks (ID 110 and streamgage 03065000 ) is 3.8 percent (the 0.491 , unitless, difference in skews discussed above); these streamgage stations are located near the southern and north-central areas of the State, respectively. 


\section{Flood-Frequency Discharges}

The flood-frequency discharges at the 290 streamgage stations on rural, unregulated streams were determined following the guidelines established by the Interagency Advisory Committee on Water Data (1982). The U.S. Geological Survey computer program PeakFQ (Flynn and others, 2006) was used to compute the flood-frequency discharges. In the analysis of flood-frequency discharges for adjacent states, information from previous studies was used (Bisese, 1995; Dillow, 1996; Stuckey and Reed, 2000; Hodgkins and Martin, 2003; and Koltun, 2003) as a reference for determining flood-frequency discharges calculated with the WV skew for use in this current study.

The $\log _{10}$-transformed systematic (continuous record or broken record that can be statistically treated as a continuous record) annual-peak series for each streamgage station was fitted to the Pearson Type III probability curve. Regional general skew (WV skew) was obtained from the map developed by Atkins and others (2009). Regional general skew is weighted with station skew to determine a final adjustment to the Pearson Type III probability curve. Additionally, highoutlier, low-outlier, and historical peak assessments were made to adjust the annual-peak series. Mixed populations, such as floods from snowmelt and those from tropical storms or hurricanes, were not analyzed separately. Selected statistics from the flood-frequency discharge analyses for the 290 streamgage stations in West Virginia and adjacent states are listed in table 2 (at the end of this report). Flood-frequency discharges determined following the guidelines established by the Interagency Advisory Committee on Water Data (1982) for 10 recurrence intervals for the 290 streamgage stations in West Virginia and adjacent states are identified as $\mathrm{Q}_{\mathrm{s}}$ in table 3 (also at the end of this report); the 10 recurrence intervals are the 1.1- (90-percent AOP), 1.5- (67-percent AOP), 2- (50-percent AOP), 5- (20-percent AOP), 10- (10-percent AOP), 25- (4-percent AOP), 50- (2-percent AOP), 100- (1-percent AOP), 200(0.5-percent AOP), and 500-year (0.2-percent AOP).

The PeakFQ computer program does not output flood-frequency discharges for all the recurrence intervals needed for this study. However, subroutines within PeakFQ (the HARTIV subroutine with related subroutines and functions, originally developed by Kirby, 1980) were used to calculate the needed flood-frequency discharges. The 1.1-year and sometimes the 1.5 -year flood discharges were computed for 15 streamgage stations using the PeakFQ subroutines; these discharges are footnoted in table 3 (at the end of this report). The identified subroutines within PeakFQ do not calculate discharge directly, but determine a frequency factor ( $K$ or "the $K$ value") that is used to calculate the discharge. A short Fortran computer program (Wiley and others, 2002, Appendix 1) was used to calculate all the frequency factors using the Bulletin-17B weighting procedures and the WV skew (Atkins and others, 2009) (table 1, at the end of this report). The short computer program uses the current versions of computer subroutines contained in a library of USGS water-resources application programs (U.S.
Geological Survey, 2001). The frequency factors are used to determine discharge by computing the antilog of discharge from the following modified equation (Interagency Advisory Committee on Water Data, 1982, equation 1, p. 9):

$$
\log _{10} Q=X_{\text {mean }}+K S_{P}
$$

where

$$
X_{\text {mean }}=\sum X / N \text {, }
$$

where

$X \quad$ is the $\log _{10}$-transformed annual peak discharges (Bulletin-17B adjusted), in $\mathrm{ft}^{3} / \mathrm{s}$; and

$N \quad$ is the number of years of peak-discharge record, unitless;

$K \quad$ is the frequency factor, unitless; and

$S_{P} \quad$ is the standard deviation of the $\log _{10^{-}}$ transformed annual peak discharges (Bulletin-17B adjusted), in $\mathrm{ft}^{3} / \mathrm{s}$ :

$$
\left[\sum\left(X-X_{\text {mean }}\right)^{2} /(N-1)\right]^{0.5} .
$$

Typically, the magnitude of a flood-frequency discharge increases with increasing drainage area. For floods with recurrence intervals greater than 10 years, however, the flood-frequency discharges calculated for the streamgage station Tygart Valley River near Dailey (ID 83 and streamgage 03050000) are greater than those for the station Tygart Valley River near Elkins (ID 84 and streamgage 03050500), although the drainage area for Tygart Valley River near Dailey $\left(185 \mathrm{mi}^{2}\right)$ is smaller than the drainage area for Tygart Valley River near Elkins $\left(271 \mathrm{mi}^{2}\right)$ (tables 2 and 3, at the end of this report). This inconsistency may be due to the wide floodplain along the river between Daily and Elkins, which contrasts with the more mountainous and narrower floodplains upstream from Daily and, therefore, increases the stream storage and attenuates the flood peak. The inconsistency also may occur because the frequency analysis for each station is based on different time periods, thus creating a time-sampling error.

Wiley and others (2000) investigated data for the streamgage station Poplar Fork at Teays (ID 248 and streamgage 03201410) for nonhomogeneity. The study concluded that the data for the period 1967 to 1978 indicate annual peaks were higher than those for 1992 to 1997, but collection of additional years of record would be necessary to resolve the question of nonhomogeneity. This current study determined that nonhomogeneity exists between the periods 1967 to 1978 and 1992 to 2007. It is hypothesized that excessive runoff from nearby impervious areas resulted in higher annual peaks for the period 1967 to 1978 . The excessive runoff no longer affects annual peaks since the streamgage station was moved to a location upstream from the nearby impervious areas for the period 1992 to 2007. The flood-frequency discharges for Popular Fork at Teays were determined using only 
annual peaks for the period 1992 to 2007 because they better represent a rural, unregulated stream.

The randomness of the systematic annual-peak series was statistically tested to detect a trend using Kendall's test for correlation (Kendall, 1975; Hirsch and others, 1982). The computer program SWSTAT (Surface Water STATistics), version 4.1, dated February 25, 2002, (Lumb and others, 1990; A.M. Lumb, W.O. Thomas, Jr., and K.M. Flynn, USGS, written commun., titled "Users manual for SWSTAT, a computer program for interactive computation of surface-water statistics," June 15, 1995) was used to calculate Kendall's tau and the level of significance (the probability or p-value). For the Kendall's test for correlation, the hypothesis that there is no trend is tested. If the hypothesis fails to attain a particular level of significance, the hypothesis of no trend is rejected. For this study, the particular level of significance selected was 0.05 , so a trend is determined for an annual-peak series if the level of significance is less than 0.05. Kendall's tau and the level of significance were determined for the annual-peak series of 246 streamgage stations (44 stations were eliminated from consideration as part of the regression analysis discussed later in this report) in West Virginia (table 2). Streamgage stations were further limited to the 125 , those with a minimum of 30 years of record, to eliminate affects that might be due to natural climatic variations (U.S. Geological Survey, 2005). The annual-peak series for 12 streamgage stations (about 10 percent of the 125 stations) indicated a trend, 7 positive and 5 negative. If chance were the only factor, 6 streamgage stations would be expected to indicate a trend (about 5 percent of the 125 stations). Statistics indicate trends at twice as many streamgage stations as would be expected by chance, but the trends were nearly equally divided between stations with positive and negative values. Therefore, no significance could be determined for the trends indicated at the 12 stations.

\section{Regional Regression of Flood-Frequency Discharges}

Regression models with the $10 \log _{10}$-transformed floodfrequency discharges as dependent variables and the 36 $\log _{10}$-transformed basin characteristics as potential independent variables were evaluated. The flood-frequency equations for the 100-year recurrence interval (1-percent AOP) were regionalized by plotting the areal distribution of residuals from the application of multiple and simple least-squares regression models. Regional regression procedures were performed using the computer program S-PLUS 7.0 (Insightful Corporation, 2005), a commercially available statistical computing package. Areal distributions of residual plots indicated three regions-Eastern Panhandle, Central Mountains, and Western Plateaus - with drainage area (DRNAREA) as the only significant independent variable (fig. 4). Initial equations for all flood-frequency discharges were determined using the regions determined by analysis of the 100 -year flood, and the outcomes of all equations identified DRNAREA as the only significant independent variable. (A regional analysis of the 2-year floods agreed with the regional divisions determined by analysis of the 100-year floods.) The final regional equations were then developed from application of a generalized leastsquare (GLS) regression model (Stedinger and Tasker, 1985; Tasker and Stedinger, 1989) (U.S. Geological Survey computer program GLSNet, version 4.0) for the three regions with DRNAREA as the only independent variable (table 4).

The three regions-Eastern Panhandle, Central Mountains, and Western Plateaus (fig. 4) - are separated by topographic features. The boundary between the Eastern Panhandle and Central Mountains Regions follows the Potomac River Basin boundary. The Central Mountains Region (from northeast to southwest) contains the drainage areas of the Cheat River, Tygart Valley River (including the Buckhannon River), Elk River upstream from the confluence of Birch River, and the New and Gauley Rivers upstream of the Kanawha River. The Western Plateaus Region encompasses the remainder of the State.

Forty-four streamgage stations were removed from the regression analysis (table 1, at the end of this report), including 12 stations in West Virginia. Thirty-two stations in adjacent states were removed primarily because residual plots indicated that the stations were not representative of flows expected in West Virginia, except for Potomac River at Hancock (ID 34 and streamgage 01613000), Shepherdstown (ID 44 and streamgage 01618000), and Point Of Rocks (ID 70 and streamgage 01638500) in Maryland where the flood-frequency discharges at these streamgage stations with large drainage areas $\left(4,075\right.$ to $\left.9,651 \mathrm{mi}^{2}\right)$ leveraged the regional regression equations, resulting in greater estimation errors for small drainage areas. The 12 streamgage stations removed from the regression analysis in West Virginia are Tuscarora Creek above Martinsburg (ID 42 and streamgage 01617000) because the station was located in a karst area of the State (equations developed in this current study are not applicable to karst areas of the state); Elk River at Centralia (ID 228 and streamgage 03195000) because the peak record for this station was used to lengthen the record for Elk River below Webster Springs (ID 227 and streamgage 03194700); Twelvepole Creek at Wayne (ID 265 and streamgage 03207000) because the peak record for this station was used to lengthen the record for Twelvepole Creek below Wayne (ID 266 and streamgage 03207020); Tug Fork near Kermit (ID 284 and streamgage 03214000) because the peak record for this station was used to lengthen the record for Tug Fork at Kermit (ID 285 and streamgage 03214500); New River at Caperton (ID 206 and streamgage 03185500 ) because the peak record for this station was used to lengthen the record for New River at Fayette (ID 207 and streamgage 03186000); Cheat River near Morgantown (ID 124 and streamgage 03071500) because the peak record for this station was used to lengthen the record for Cheat River near Pisgah (ID 123 and streamgage 03071000); and Potomac River at Paw Paw (ID 28 and streamgage 01610000), Shenandoah River at Millville (ID 66 and streamgage 01636500), New River at Bluestone Dam (ID 188 and streamgage 03180000), New River at 


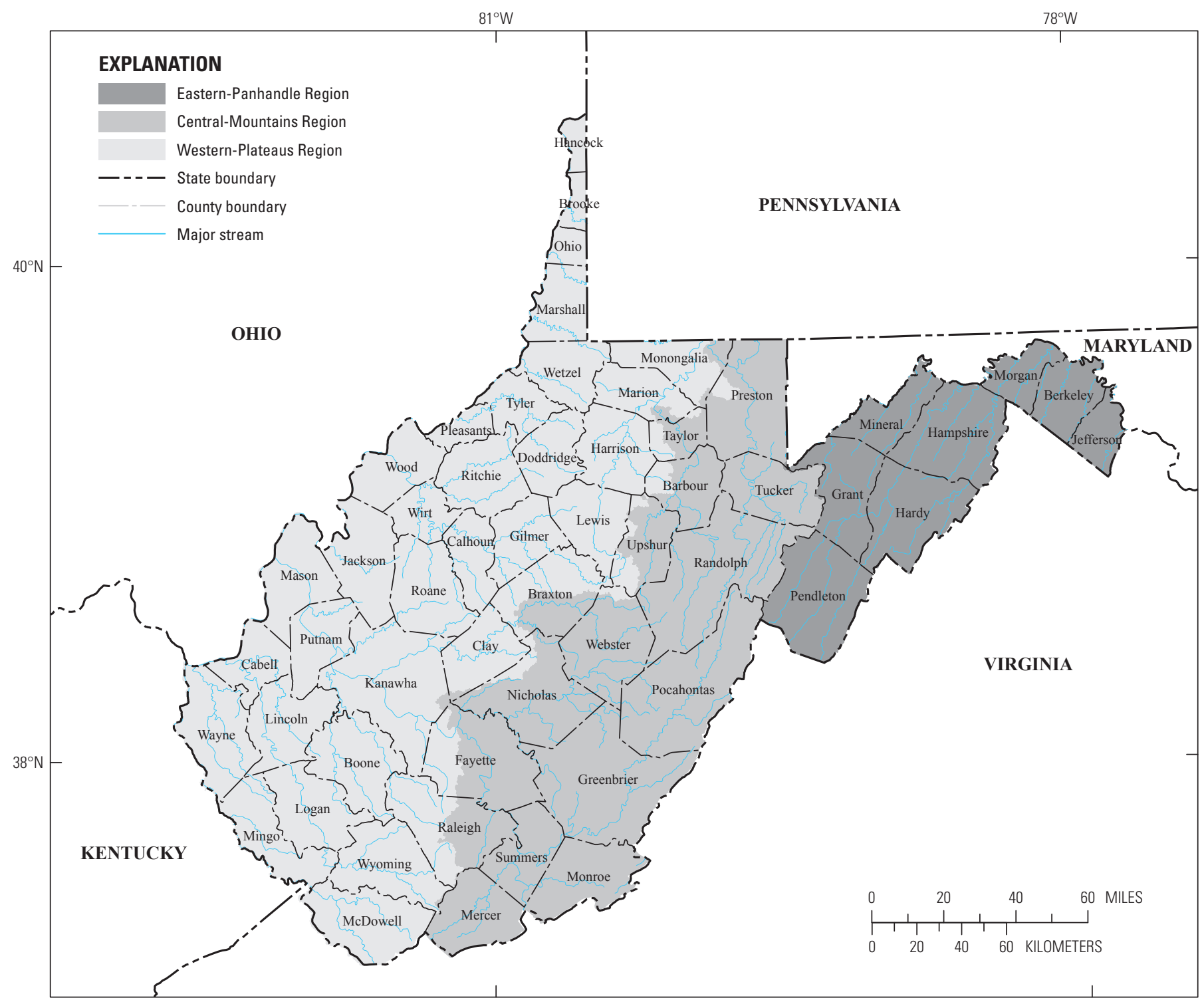

Base from U.S. Geological Survey 1:100,000 digital line graphics for state boundaries and streams and

from the West Virginia Department of Environmental Protection 1:24,000 digital data for county boundaries.

Universal Transverse Mercator projection, zone 17, NAD 83.

Figure 4. The Eastern Panhandle, Central Mountains, and Western Plateaus Regions of West Virginia for which equations for estimation of flood frequency discharges were developed in this study. 
Table 4. Equations used to estimate selected flood-frequency discharges for streams in the Eastern Panhandle, Central Mountains, and Western Plateaus Regions of West Virginia.

[PK $\left(n \_n\right)$, peak discharge in cubic feet per second for the (n.n)-year recurrence interval; PK(n), peak discharge in cubic feet per second for the (n)-year recurrence interval; \%, percent; AOP, annual-occurrence probability; DRNAREA, drainage area in square miles]

\begin{tabular}{|c|c|c|c|c|}
\hline Equation & $\begin{array}{l}\text { Standard error } \\
\text { of the model, } \\
\text { in percent }\end{array}$ & $\begin{array}{l}\text { Average standard } \\
\text { error of sampling, } \\
\text { in percent }\end{array}$ & $\begin{array}{c}\text { Average } \\
\text { prediction error, } \\
\text { in percent }\end{array}$ & $\begin{array}{l}\text { Equivalent years } \\
\text { of record, } \\
\text { unitless }\end{array}$ \\
\hline \multicolumn{5}{|c|}{ Eastern Panhandle Region (Range in DRNAREA from 0.21 to 1,461 for 57 streamgage stations) } \\
\hline PK1_1 $(90 \%$ AOP $)=29.6$ DRNAREA ${ }^{0.818}$ & 43.4 & 10.3 & 44.8 & 3.4 \\
\hline PK1_5(67\%AOP $)=46.4$ DRNAREA ${ }^{0.828}$ & 35.7 & 8.9 & 36.9 & 3.3 \\
\hline PK2 $(50 \%$ AOP $)=59.8$ DRNAREA $^{0.832}$ & 32.1 & 8.6 & 33.4 & 4.1 \\
\hline PK5 $(20 \%$ AOP $)=105$ DRNAREA ${ }^{0.838}$ & 25.6 & 8.9 & 27.2 & 10.6 \\
\hline PK10 $(10 \% A O P)=145$ DRNAREA $^{0.842}$ & 22.5 & 9.5 & 24.5 & 19.1 \\
\hline PK25 $(4 \%$ AOP $)=204$ DRNAREA $^{0.848}$ & 19.7 & 10.3 & 22.4 & 34.1 \\
\hline PK50 $(2 \%$ AOP $)=254$ DRNAREA $^{0.852}$ & 18.6 & 11.1 & 21.7 & 46.1 \\
\hline PK100 $(1 \%$ AOP $)=307$ DRNAREA $^{0.855}$ & 18.3 & 11.6 & 21.7 & 56.7 \\
\hline PK200 $(0.5 \%$ AOP $)=365$ DRNAREA ${ }^{0.859}$ & 18.4 & 12.4 & 22.4 & 64.7 \\
\hline PK500 $(0.2 \%$ AOP $)=447$ DRNAREA ${ }^{0.864}$ & 19.4 & 13.5 & 23.8 & 70.9 \\
\hline \multicolumn{5}{|c|}{ Central Mountains Region (Range in DRNAREA from 0.10 to 1,619 for 83 streamgage stations) } \\
\hline PK1_1 $(90 \% A O P)=33.4$ DRNAREA 0.914 & 40.0 & 8.3 & 41.0 & 2.4 \\
\hline PK1_5(67\%AOP $)=53.8$ DRNAREA ${ }^{0.887}$ & 34.6 & 7.3 & 35.4 & 2.0 \\
\hline PK2 $(50 \% A O P)=69.4$ DRNAREA $^{0.873}$ & 33.4 & 7.3 & 34.2 & 2.1 \\
\hline PK5 $(20 \%$ AOP $)=116$ DRNAREA ${ }^{0.845}$ & 34.1 & 8.0 & 35.1 & 3.2 \\
\hline PK10 $(10 \% A O P)=153$ DRNAREA ${ }^{0.831}$ & 36.3 & 8.6 & 37.4 & 4.0 \\
\hline PK25 $(4 \%$ AOP $)=206$ DRNAREA $^{0.816}$ & 39.9 & 9.8 & 41.2 & 4.8 \\
\hline PK50 $(2 \%$ AOP $)=250$ DRNAREA $^{0.807}$ & 42.9 & 10.6 & 44.4 & 5.3 \\
\hline PK100 $(1 \%$ AOP $)=297$ DRNAREA ${ }^{0.800}$ & 46.2 & 11.3 & 47.9 & 5.6 \\
\hline PK200 $(0.5 \%$ AOP $)=347$ DRNAREA ${ }^{0.793}$ & 49.7 & 12.0 & 51.5 & 5.9 \\
\hline PK500 $(0.2 \%$ AOP $)=420$ DRNAREA $^{0.785}$ & 54.3 & 13.1 & 56.3 & 6.1 \\
\hline \multicolumn{5}{|c|}{ Western Plateaus Region (Range in DRNAREA from 0.13 to 1,516 for 106 streamgage stations) } \\
\hline PK1_1 $1(90 \%$ AOP $)=56.9$ DRNAREA ${ }^{0.763}$ & 38.2 & 7.6 & 39.1 & 3.8 \\
\hline PK1_5(67\%AOP $)=97.8$ DRNAREA ${ }^{0.741}$ & 33.4 & 6.5 & 34.1 & 2.8 \\
\hline PK2 $(50 \%$ AOP $)=129$ DRNAREA ${ }^{0.730}$ & 31.6 & 6.1 & 32.2 & 2.8 \\
\hline PK5 $(20 \%$ AOP $)=221$ DRNAREA ${ }^{0.710}$ & 29.3 & 6.5 & 30.0 & 4.4 \\
\hline PK10 $(10 \% A O P)=292$ DRNAREA $^{0.699}$ & 28.9 & 6.5 & 29.7 & 5.9 \\
\hline PK25 $(4 \%$ AOP $)=391$ DRNAREA ${ }^{0.688}$ & 29.4 & 7.3 & 30.3 & 7.9 \\
\hline PK50 $(2 \%$ AOP $)=472$ DRNAREA $^{0.681}$ & 30.2 & 7.6 & 31.3 & 9.1 \\
\hline PK100 $(1 \% A O P)=557$ DRNAREA ${ }^{0.674}$ & 31.4 & 8.0 & 32.5 & 10.1 \\
\hline PK200 $(0.5 \%$ AOP $)=647$ DRNAREA ${ }^{0.668}$ & 32.7 & 8.3 & 33.9 & 10.8 \\
\hline PK500 $(0.2 \%$ AOP $)=775$ DRNAREA ${ }^{0.661}$ & 34.8 & 8.9 & 36.1 & 11.4 \\
\hline
\end{tabular}


Hinton (ID 203 and streamgage 03184500), New River at Fayette (ID 207 and streamgage 03186000), and Kanawha River at Kanawha Falls (ID 224 and streamgage 03193000) because the flood-frequency discharges at these stations with large drainage areas $\left(4,602\right.$ to $\left.8,371 \mathrm{mi}^{2}\right)$ leveraged the regional regression equations, resulting in greater estimation errors for small drainage areas.

\section{Accuracy of Flood-Frequency Discharge Equations}

The accuracy of equations used to estimate discharge is quantified by calculating the average prediction error (Tasker and Stedinger, 1989; Hodge and Tasker, 1995) and equivalent years of record (Hardison, 1969, 1971). Average prediction error is the square root of the sum of the squared standard error of the model (the portion of the total error due to an imperfect model) and the average squared standard error of sampling (the portion of the total error due to estimating model parameters from a sample), in log units. The average prediction errors range from 21.7 to 56.3 percent (table 4). The average prediction error is within 3.4 percentage points of the standard error of the model for all regression equations, indicating that addition of the average standard error of sampling to the standard error of the model accounts for very little additional unexplained variance of the flood-frequency discharge estimate.

Also, the average prediction error is the square root of the average of individual squared standard errors of prediction. Individual standard errors of prediction for the regression equations shown in table 4 were computed over the entire range of applicable drainage areas and compared to the average prediction errors (fig. 5). The $\mathrm{x}$-axis of figure 5 is not to scale because the minimum and maximum drainage areas are unequal among regions. The individual standard errors of prediction were computed using the matrices presented in Appendix 1 and methods described by Hodge and Tasker (1995, p. 37-42), Wiley and others (2000, Appendix 1), Wiley and others (2002, Appendix 2), and Koltun (2003, Appendix A). The individual standard errors of prediction increase for drainage areas less than and greater than about $100 \mathrm{mi}^{2}$ (where the individual standard errors are 1.0 percentage point less than average prediction error) for all regression equations. The maximum individual standard errors of prediction for the maximum drainage areas are within 0.5 percentage point of the average standard error of prediction for all regression equations. The maximum individual standard errors of prediction for the minimum drainage areas are less than 5.8 percentage points greater than the average prediction error for all regression equations. The individual standard errors of prediction are about equal (within 0.3 percentage point) to the average prediction error at $10 \mathrm{mi}^{2}$ for all regression equations. In summary, the individual standard errors of prediction are within 1.0 percentage point of the average prediction error for drainage areas greater than $10 \mathrm{mi}^{2}$, and the individual standard

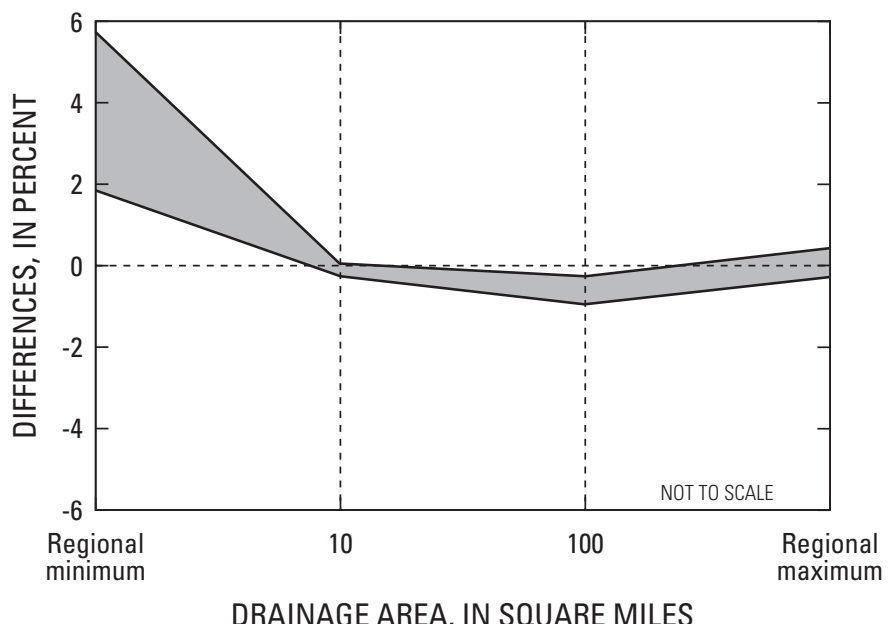

Figure 5. Range of differences (shaded) of the individual standard errors of the prediction from the average prediction errors for the indicated drainage areas. The graph represents all regional equations.

errors of prediction increase to a maximum of 5.8 percentage points greater than the average standard error of prediction for the minimum drainage areas.

It is not necessary to compute the individual standard errors of prediction when using the regression equations developed in this study for drainage areas greater than or equal to about $10 \mathrm{mi}^{2}$ because the differences between the individual standard errors of prediction and average prediction error are insignificant (within 1.0 percentage point). Also, it is not necessary to compute the individual standard errors of prediction for drainage areas less than about $10 \mathrm{mi}^{2}$ if an additional error of up to 5.8 percentage points (the maximum of individual standard errors of prediction for the minimum drainage areas) is acceptable for the particular application.

Equivalent years of record (table 4) is an estimate of the number of systematic years of record that must be collected at a streamgage station to calculate flood-frequency discharges with an accuracy equal to that of the regional equation. The equivalent years of record ranged from 2.0 to 70.9 years. The equivalent years of record is not a direct measurement of accuracy between equations of flood-frequency discharges. A comparison of the equation for PK1_1 (90\% AOP) to that for PK25 (4\% AOP) in the Eastern Panhandle Region shows that the equivalent years of record increased 10 times (3.4 to 34.1), but the average prediction error decreased only by half ( 44.8 to 22.4). Equivalent years of record is a weighting factor that is applied when determining flood-frequency discharges at streamgage stations.

The high values for the equivalent years of record in the Eastern Panhandle Region are atypical compared to values for flood-frequency equations in surrounding states and the previous study in West Virginia. The atypical high values are probably due to (1) a good correlation with the distance 
between stations for weighting in the GLS regression compared to the correlations for other regions in this study; (2) unusually low residuals for short-term streamgage stations (less than 15 years) that have small drainage areas (less than $5 \mathrm{mi}^{2}$ ) compared to residuals for other regions in this study, the previous study in West Virginia, and regression studies for other hydrologic statistics conducted by the authors; and (3) the longer average record length for stations in the Eastern Panhandle Region (41) compared to average record lengths in the Central Mountains (39) and Western Plateaus (33).

\section{Procedures For Estimating Flood- Frequency Discharges}

Estimating procedures for the 1.1- (90-percent AOP), 1.5(67-percent AOP), 2- (50-percent AOP), 5- (20-percent AOP), 10- (10-percent AOP), 25- (4-percent AOP), 50- (2-percent AOP), 100- (1-percent AOP), 200- (0.5-percent AOP), and 500-year (0.2-percent AOP) flood discharges were developed for streamgage stations and ungaged locations in West Virginia.

\section{At a Streamgage Station}

A flood-frequency discharge at a streamgage station is determined by reading the weighted $\left(Q_{w}\right)$ value directly from table 3 (at the end of this report). This discharge was calculated by weighting (1) the discharge determined from the systematic and historical record ( $Q_{s}$ in table 3$)$, using the guidelines established by the Interagency Advisory Committee on Water Data (1982) with the WV skew, and (2) the discharge determined by the appropriate regional regression equation $\left(Q_{r}\right.$ in table 3). The weighting technique considers (1) the number of years of peak-discharge record which equals the number of years of systematic record, plus the number of historical peaks, minus the number of high-outlier peaks (values from table 2, at the end of this report), and (2) the number of equivalent years of record (an estimate given in table 4 of the number of systematic years of record for a streamgage station necessary to calculate flood-frequency discharges with an accuracy equal to that of the regional regression equation). The following equation was used.

$$
Q_{w}=\left(Q_{s} N+Q_{r} E_{Y}\right) /\left(N+E_{Y}\right),
$$

where

$Q_{w} \quad$ is the weighted discharge, in $\mathrm{ft}^{3} / \mathrm{s}$;

$Q_{s} \quad$ is the flood-frequency discharge determined from the systematic and historical record using the guidelines established by the Interagency Advisory Committee on Water Data (1982), in $\mathrm{ft}^{3} / \mathrm{s}$;

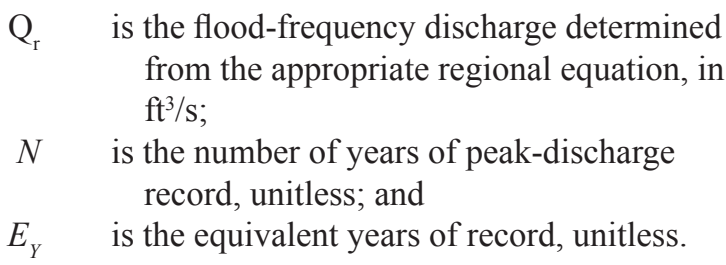

No weighted value was calculated for one of the two streamgage stations on the same stream that were combined into a single time-series record; the flood-frequency discharge near (at) the streamgage station without a weighted value is to be determined using procedures for an ungaged location. No weighted value was calculated for Tuscarora Creek above Martinsburg (ID 42 and streamgage 01617000) because the streamgage station is located in a karst area of the State; the frequency discharge of the systematic record $\left(Q_{s}\right)$ is to be used at this station.

\section{At an Ungaged Location}

Four different procedures are used to determine a flood-frequency discharge at an ungaged location (1) when the ungaged location is upstream from a streamgage station, (2) when the ungaged location is downstream from a streamgage station, (3) when the ungaged location is between two streamgage stations on the same stream, and (4) when the ungaged location is not on the same stream as a streamgage station. Two locations were considered to be on the same stream when the stream path from the downstream location to the basin divide followed the stream segment with the largest drainage area at each stream confluence and passed through the upstream location.

It is necessary to determine if the ungaged location is near a streamgage station, and arithmetic methods are used to quantify the definition of "near." A drainage-area-ratio method for estimating statistics at ungaged locations has been used by several researchers, including Hayes (1991), Ries and Friesz (2000), Flynn (2003), and Wiley (2008). The ratio of the drainage areas $\left(R_{U / K}\right)$ is defined as the ratio of the drainage area where the flood-frequency discharge is unknown $\left(A_{U}\right)$ to the drainage area where the flood-frequency discharge is known $\left(A_{K}\right)$. These researchers use arithmetic methods for determining the upstream and downstream limits of the range of drainage-area ratios over which flood-frequency discharges can be accurately estimated from those at a streamgage station using an equation similar to the following:

$$
Q_{U}=Q_{K}\left(R_{U / K}\right)^{E X}
$$

where

$$
\begin{aligned}
& Q_{U} \quad \text { is the unknown flood-frequency discharge, in } \\
& \mathrm{ft}^{3} / \mathrm{s} ; \\
& Q_{K} \quad \text { is the known flood-frequency discharge, in } \\
& \mathrm{ft}^{3} / \mathrm{s} ;
\end{aligned}
$$


$R_{U / K} \quad$ is the ratio of the drainage area at the location of the unknown flood-frequency discharge $\left(A_{U}\right)$ to the drainage area at the location of the known flood-frequency discharge $\left(A_{K}\right)$, unitless; and

$E X \quad$ is the exponent for the particular floodfrequency discharge, unitless.

The 1.1-, 1.5-, 2-, 5-, 10-, 25-, 50-, 100-, 200-, and 500year flood discharges at 88 pairs of streamgage stations located on the same stream in West Virginia and adjacent states (table 5, at the end of this report) were evaluated to quantify "near" for application of the drainage-area-ratio method in this study. Two computations, one upstream and one downstream, were made for each pair of stations. Ratios of the drainage areas for the 176 computations ranged from 0.038 to 26.4. Equation 5 was solved for the exponent $(E X)$ as the dependent variable:

$$
\log _{10}\left(Q_{U} / Q_{K}\right)=E X\left(\log _{10}\left(R_{U / K}\right)\right) .
$$

The exponent was evaluated for the 88 pairs of streamgage stations for each flood-frequency discharge using simple linear regression with no intercept (regression line goes through the graph origin). The values of the exponent $(E X)$ for the flood-frequency discharges ranged from 0.68 to 0.79 (table 6).

The upstream and downstream limits for application of drainage-area ratios used to quantify the definition of "near" were determined by plotting the $\mathrm{x}$-axis as the drainage-area ratios and the $y$-axis as the absolute percent differences between the flood-frequency discharges at the streamgage station $\left(Q_{w}\right)$ and the flood-frequency discharges estimated by applying (1) the drainage-area-ratio method and (2) the regional equations $\left(Q_{r}\right)$. S-PLUS 7.0 was used to construct locally weighted regression (LOESS) curves (a data-smoothing technique) through differences between flood-frequency discharges computed from streamgage-station records and the estimated values (selected LOESS parameters were "span = 0.5 ; degree $=$ one, locally linear fitted; family $=$ Symmetric, no feature for handling outlier distortions, strictly applying locally linear fitting"). The absolute percent differences for estimates of the 100-year flood made by applying the drainage-area-ratio method are lower than the estimates made by applying the regional equation at drainage-area ratios greater than about 0.40 (fig. 6). Similar results were determined for all flood frequencies estimated in this study, and absolute percent differences for all equations were combined to determine ratio limits applicable for all flood frequencies (fig. 7). The upstream limit used to quantify the definition of "near" for all flood frequencies was determined to be 0.40 , and the downstream limit was set to the maximum ratios studied, 26.4, because no assessment could be made for ratios greater than 26.4 (table 6).
The downstream limit of 26.4 for application of drainagearea ratios determined in this study is much greater than values determined by Hayes (1991), Ries and Friesz (2000), and Flynn (2003), probably because the streamgage stations used to compute ratios in this study were limited to those on the same stream (the stream path from the downstream location to the basin divide followed the stream segment with the largest drainage area at each stream confluence and passed through the upstream location). The downstream limit of 26.4 determined in this study is much greater than the value of 4.76 determined by Wiley (2008), but both studies used LOESS plots to set the downstream limit to the maximum ratio studied.

The upstream limit of 0.40 for application of drainagearea ratios determined in this study was equal to that determined by Wiley (2008) for flood frequencies at and below the 10 -year recurrence interval. The upstream limit of 0.21 for flood frequencies at and above the 25 -year recurrence interval determined by Wiley (2008) is superseded by the value 0.40 determined in this study because more than three times as many pairs of stations were used to determine the value in this study (26 pairs compared to 88 pairs).

Table 6. Values of the exponent, and upstream and downstream limits of the drainage-area ratios used to quantify the definition of "near" for estimating selected flood-frequency discharges for ungaged locations in West Virginia.

[EX, exponent; $\mathrm{R}_{\mathrm{US}}$, upstream limit of the drainage-area ratio; $\mathrm{R}_{\mathrm{DS}}$, downstream limit of the drainage-area ratio; $\mathrm{PK}\left(\mathrm{n} \_\mathrm{n}\right)$, peak discharge in cubic feet per second for the (n.n)-year recurrence interval; $\mathrm{PK}(\mathrm{n})$, peak discharge in cubic feet per second for the (n)-year recurrence interval; \%, percent; AOP, annual-occurrence probability]

\begin{tabular}{cccc}
\hline Statistic & EX & $\mathbf{R}_{\mathrm{US}}$ & $\mathbf{R}_{\mathrm{DS}}$ \\
\hline PK1_1(90\%AOP) & 0.79 & 0.40 & 26.4 \\
\hline PK1_5(67\%AOP) & .76 & .40 & 26.4 \\
\hline PK2(50\%AOP) & .75 & .40 & 26.4 \\
\hline PK5(20\%AOP) & .73 & .40 & 26.4 \\
\hline PK10(10\%AOP) & .72 & .40 & 26.4 \\
\hline PK25(4\%AOP) & .71 & .40 & 26.4 \\
\hline PK50(2\%AOP) & .70 & .40 & 26.4 \\
\hline PK100(1\%AOP) & .70 & .40 & 26.4 \\
\hline PK200(0.5\%AOP) & .69 & .40 & 26.4 \\
\hline PK500(0.2\%AOP) & .68 & .40 & 26.4 \\
\hline
\end{tabular}



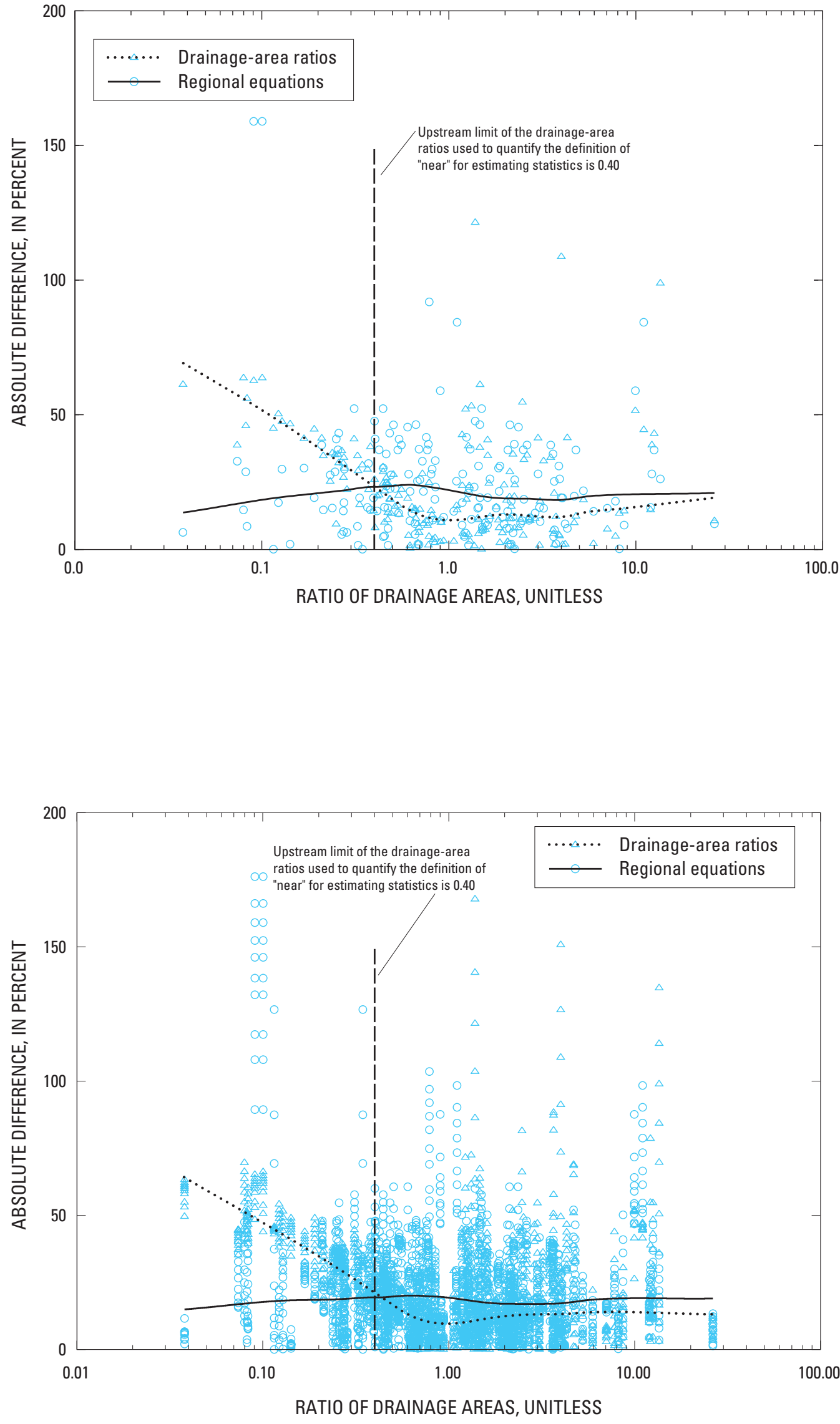

Figure 6. LOESS curves of the absolute difference between the 100-year (1-percent annualoccurrence probability) flood discharges determined at streamgage stations and values estimated from the (1) drainage-area ratio method and (2) regional equations, in relation to the ratios of the drainage areas.

Figure 7. LOESS curves of the absolute difference between the 1.1- through 500 -year (90- through 0.2-percent annualoccurrence probabilities) flood discharges determined at streamgage stations and values estimated from the (1) drainage-area ratio method and (2) regional equations, in relation to the ratios of the drainage areas. 


\section{Upstream From a Streamgage Station}

This procedure is used when there is a streamgage station downstream from the ungaged location but none upstream on the same stream. The hydrologic assumption for this circumstance is that the conditions affecting flood-frequency discharges, such as land cover, basin topography, and climatic conditions, are unchanged upstream from the streamgage station. Mathematically, the values of flood-frequency discharges are proportioned by drainage area. It is suggested that a streamgage be established when $R_{U / K}$ is less than or equal to the upstream limit of the ratio of drainage areas $\left(R_{U S}\right)$ (table 6). The following equation is used to estimate flood-frequency discharges:

$$
Q_{U}=Q_{K}\left(R_{U / K}\right)^{E X}
$$

where

$$
\begin{array}{cl}
Q_{U} \quad \begin{array}{l}
\text { is the unknown flood-frequency discharge, } \\
\text { in } \mathrm{ft}^{3} / \mathrm{s} ;
\end{array} \\
\mathrm{Q}_{K} \quad \begin{array}{l}
\text { is the known flood-frequency discharge } \\
\text { (table 3), in } \mathrm{ft}^{3} / \mathrm{s} ;
\end{array} \\
\begin{array}{c}
\text { is the ratio of the drainage area at the location } \\
\text { of the unknown flood-frequency discharge } \\
\left(A_{U}\right) \text { to the drainage area at the location of } \\
\text { the known flood-frequency discharge }\left(A_{K}\right), \\
\text { unitless; and }
\end{array} \\
\begin{array}{l}
\text { is the exponent for the particular flood- } \\
\text { frequency discharge (table } 6), \text { unitless. }
\end{array}
\end{array}
$$

In this method, it is not assumed that the conditions affecting flood-frequency discharges change in the upstream direction toward the regional tendency. The critical situation for this assumption is where the unknown location approaches the headwaters of a stream. This assumption might be acceptable if the flood-frequency discharge at the known location is less than that estimated by applying the regional equation at the known location because the upstream estimate of the flood-frequency discharge would be greater, and therefore, more conservative from a flood inundation perspective than that determined using the method presented. However, this assumption would be unacceptable if the flood-frequency discharge at the known location is greater than that estimated by applying the regional equation because the upstream estimate of flood-frequency discharge would be less than that determined using the method presented, thus requiring an assumption of reducing unit inflow. The method presented would require establishing a streamgage station in order to reduce unit inflow when the known flood-frequency discharge is greater than that estimated using the regional equation.

\section{Downstream From a Streamgage Station}

This procedure is used when there is a streamgage station upstream from the ungaged location but none downstream on the same stream. The hydrologic assumption for this circumstance is that the conditions affecting flood-frequency discharges at the streamgage station change, in the downstream direction, toward those of the regional tendency. The conditions affecting flood-frequency discharges in the vicinity of the streamgage station could be atypical impervious land cover, unusual basin slope, uncommon basin orientation, or diversion of storm runoff that likely would not significantly affect flood-frequency discharges if the drainage area were larger and, therefore, conditions were more similar to the regional tendency. Mathematically, the value of a flood-frequency discharge is changed to that estimated by applying the regional equation as $R_{U / K}$ approaches the downstream limit of the ratio of drainage areas $\left(R_{D S}\right)$ (table 6). It is suggested that a streamgage be established when $R_{U / K}$ is greater than or equal to $R_{D S}$. The flood-frequency discharge is estimated by applying the regional equation when $R_{U / K}$ is greater than or equal to $R_{D S}$, and the following equation is used to estimate the floodfrequency discharge when $R_{U / K}$ is less than $R_{D S}$ :

$$
Q_{U}=Q_{U E}+\left(Q_{K}-Q_{K E}\right)\left(R_{D S}-R_{U / K}\right) /\left(R_{D S}-1\right),
$$

when

$$
R_{U / K}<R_{D S} ; \text { and }
$$

where

$$
\begin{aligned}
& Q_{U} \quad \text { is the unknown flood-frequency discharge, } \\
& \text { in } \mathrm{ft}^{3} / \mathrm{s} \text {; } \\
& Q_{U E} \quad \text { is the regional equation (table 4) evaluated } \\
& \text { at the location of the unknown flood- } \\
& \text { frequency discharge, in } \mathrm{ft}^{3} / \mathrm{s} \text {; } \\
& Q_{K} \quad \text { is the known flood-frequency discharge } \\
& \text { (table } 3 \text { ), in } \mathrm{ft}^{3} / \mathrm{s} \text {; } \\
& Q_{K E} \quad \text { is the regional equation (table 4) evaluated at } \\
& \text { the location of the known flood-frequency } \\
& \text { discharge, in } \mathrm{ft}^{3} / \mathrm{s} \text {; } \\
& R_{D S} \quad \text { is the downstream limit of the ratio of } \\
& \text { drainage areas (table 6), unitless; and } \\
& R_{U / K} \quad \text { is the ratio of the drainage area at the location } \\
& \text { of the unknown flood-frequency discharge } \\
& \left(A_{U}\right) \text { to the drainage area at the location of } \\
& \text { the known flood-frequency discharge }\left(A_{K}\right) \text {, } \\
& \text { unitless. }
\end{aligned}
$$

\section{Between Streamgage Stations}

This procedure is used when there are streamgage stations both upstream and downstream from the ungaged location on the same stream. The hydrologic assumption for this circumstance is that the conditions affecting flood-frequency discharges are changing on the basis of the relation between the flood-frequency discharges at the streamgage stations, the ratios of the drainage areas, and differences between regional hydrologic conditions and those that affect flood-frequency discharges at the stations. It is suggested that a streamgage be established when $R_{U / K}$ is greater than $R_{D S}$ and less than $R_{U S}$, 
and when one of the values of the flood-frequency discharge at the upstream and downstream locations is greater than, and one of the values is less than, that estimated by applying the regional equation. Two alternative hydrologic assumptions are described in detail below.

\section{Hydrologic Conditions Change Linearly between Streamgage Stations}

This hydrologic assumption is that the conditions affecting flood-frequency discharges at the upstream streamgage station change linearly with drainage area to those at the downstream location when (1) both streamgage stations are near the ungaged location, or (2) both streamgage stations are not near the ungaged location, but the hydrologic conditions affecting flood-frequency discharges at the stations and ungaged location are consistent. The conditions affecting flood-frequency discharges between the upstream and downstream locations are well defined by streamgage stations when both are near the ungaged location; the conditions affecting flood-frequency discharges are consistent from the upstream to the downstream location when neither is near the ungaged location and the conditions at both stations are more similar to each other than to the regional hydrologic conditions. Mathematically, the value of flood-frequency discharges changes linearly with respect to drainage area from the upstream to the downstream value when (1) $R_{U / K}$ is less than $R_{D S}$ at the upstream location and $R_{U / K}$ is greater than $R_{U S}$ at the downstream location; or (2) $R_{U / K}$ is greater than or equal to $R_{D S}$ at the upstream location, $R_{U / K}$ is less than or equal to $R_{U S}$ at the downstream location, and the discharges of the flood frequencies at the upstream and downstream locations are both greater than or both less than those estimated by applying the regional equation. The following equation is used to estimate the flood-frequency discharge under the limitations described above:

$$
Q_{U}=\left[Q_{U S}\left(A_{D S}-A_{U}\right)+Q_{D S}\left(A_{U}-A_{U S}\right)\right] /\left(A_{D S}-A_{U S}\right),
$$

when

$R_{U / K}<R_{D S}$ at upstream location and

$R_{U / K}>R_{U S}$ at downstream location,

or when

$R_{U / K} \geq R_{D S}$ at upstream location and

$R_{U / K} \leq R_{U S}$ at downstream location; and

$Q_{K E}$ at the upstream location $>Q_{U S}$ and

$Q_{K E}$ at the downstream location $>Q_{D S}$ or

$Q_{K E}$ at the upstream location $<Q_{U S}$ and

$Q_{K E}$ at the downstream location $<Q_{D S}$; and where

$Q_{U} \quad$ is the unknown flood-frequency discharge, in $\mathrm{ft}^{3} / \mathrm{s}$;

$Q_{U S} \quad$ is the flood-frequency discharge at the upstream location (table 3 ), in $\mathrm{ft}^{3} / \mathrm{s}$;

$Q_{D S} \quad$ is the flood-frequency discharge at the downstream location (table 3 ), in $\mathrm{ft}^{3} / \mathrm{s}$;

$Q_{K E} \quad$ is the regional equation evaluated at the location of the known flood-frequency discharge, in $\mathrm{ft}^{3} / \mathrm{s}$;

$A_{U} \quad$ is the drainage area at the location of the unknown flood-frequency discharge, in $\mathrm{mi}^{2}$;

$A_{U S} \quad$ is the drainage area at the upstream location (table 2), in $\mathrm{mi}^{2}$;

$A_{D S} \quad$ is the drainage area at the downstream location (table 2), in $\mathrm{mi}^{2}$;

$R_{U S} \quad$ is the upstream limit of the ratio of drainage areas (table 5), unitless; and

$R_{D S} \quad$ is the downstream limit of the ratio of drainage areas (table 5), unitless.

\section{Hydrologic Conditions Change Linearly to the Regional} Hydrologic Conditions between Streamgage Stations

This hydrologic assumption is that the conditions affecting flood-frequency discharges at the streamgage station change linearly with drainage area to those represented by the regional equation when neither streamgage station is near the ungaged location and the hydrologic conditions affecting flood-frequency discharges at the two stations are inconsistent. The conditions affecting flood discharges can vary greatly as a result of factors such as (1) significant changes in land cover, basin topography, or climatic conditions; (2) input from a tributary stream that is hydrologically different from the stream on which the streamgage station is located or from regional hydrologic conditions; or (3) transfer of storm runoff into or out of the basin. Mathematically, the hydrologic conditions are inconsistent if one of the flood-frequency discharges at the upstream and downstream locations is greater than and one of the flood-frequency discharges is less than those estimated by applying the regional equation - that is, the floodfrequency discharge changes from a value greater than the flood-frequency discharge estimated by applying the regional equation at the upstream location to a value equal to the floodfrequency discharge estimated from the regional equation, and then to a value less than the flood-frequency discharge estimated from the regional equation at the downstream location, or the reverse. The regional equation (table 4) is applied to estimate the flood-frequency discharge if $R_{U / K}$ is greater than or equal to $R_{D S}$ at the upstream location and $R_{U / K}$ is less than or equal to $R_{U S}$ at the downstream location. Equation 8 presented in the section "Downstream from a Streamgage Station" is used to estimate the flood-frequency discharge if $R_{U / K}$ is less than $R_{D S}$ at the upstream location and $R_{U / K}$ is less than or equal 
to $R_{U S}$ at the downstream location. The following equation is used to estimate the flood-frequency discharge if $R_{U / K}$ is greater than or equal to $R_{D S}$ at the upstream location and $R_{U / K}$ is greater than $R_{U S}$ at the downstream location:

$$
Q_{U}=Q_{U E}+\left(Q_{K}-Q_{K E}\right)\left(R_{U / K}-R_{U S}\right) /\left(1-R_{U S}\right),
$$

when

$R_{U / K} \geq R_{D S}$ at upstream location and

$R_{\mathrm{U} / \mathrm{K}}>R_{U S}$ at downstream location, and

where

$$
\begin{aligned}
& Q_{U} \quad \text { is the unknown flood-frequency discharge, in } \\
& \mathrm{ft}^{3} / \mathrm{s} \text {; } \\
& Q_{\mathrm{UE}} \quad \text { is the regional equation (table 4) evaluated } \\
& \text { at the location of the unknown flood- } \\
& \text { frequency discharge, in } \mathrm{ft}^{3} / \mathrm{s} \text {; } \\
& Q_{K} \quad \text { is the known flood-frequency discharge } \\
& \text { (table } 3 \text { ), in } \mathrm{ft}^{3} / \mathrm{s} \text {; } \\
& Q_{K E} \quad \text { is the regional equation (table 4) evaluated at } \\
& \text { the location of the known flood-frequency } \\
& \text { discharge, in } \mathrm{ft}^{3} / \mathrm{s} \text {; } \\
& R_{D S} \quad \text { is the downstream limit of the ratio of } \\
& \text { drainage areas (table 5), unitless; } \\
& R_{U S} \quad \text { is the upstream limit of the ratio of drainage } \\
& \text { areas (table 5), unitless; and } \\
& R_{U / K} \quad \text { is the ratio of the drainage area at the location } \\
& \text { of the unknown flood-frequency discharge } \\
& \left(A_{U}\right) \text { to the drainage area at the location of } \\
& \text { the known flood-frequency discharge }\left(A_{K}\right) \text {, } \\
& \text { unitless. }
\end{aligned}
$$

\section{Not on the Same Stream as a Streamgage Station}

This procedure is used when there is no streamgage station on the same stream as the ungaged location. The hydrologic assumption for this circumstance is that the conditions affecting flood-frequency discharges are those represented by the regional equation. A streamgage station could be established when there is no streamgage station on the same stream as the ungaged location. Mathematically, the flood-frequency discharge is estimated by applying the regional equation (table 4).

\section{Example Applications}

Estimates of flood-frequency discharges are made by directly reading from table 3 when the location of interest is at a streamgage station, or using one of the four procedures at an ungaged location: (1) when the ungaged location is upstream from a streamgage station, (2) when the ungaged location is downstream from a streamgage station, (3) when the ungaged location is between two streamgage stations on the same stream, and (4) when the ungaged location is not on the same stream as a streamgage station.

- At a streamgage station: A flood-frequency discharge for a streamgage station is determined by reading the weighted $\left(Q_{w}\right)$ value from table 3 . For example, the 500-year flood discharge (PK500, 0.2-percent AOP) at the streamgage station Big Coal River at Ashford (ID 238 and streamgage 03198500) is given as $50,300 \mathrm{ft}^{3} / \mathrm{s}$.

- Upstream from a streamgage station: The 50-year flood discharge (PK50, 2-percent AOP) for the South Fork South Branch Potomac River just downstream from the confluence of George Run in Pendleton County (Sugar Grove 71/2-minute U.S. Geological Survey topographic map) and upstream from the streamgage station at Brandywine (ID 19 and streamgage 01607500) can be calculated using equation 7. The known 50-year flood discharge $\left(Q_{K}\right)$ at the Brandywine streamgage station is $18,600 \mathrm{ft}^{3} / \mathrm{s}$ (the value for $Q_{w}$ from table 3$)$. The drainage area at the unknown location $\left(A_{U}\right)$ is $84.56 \mathrm{mi}^{2}$ (Wiley and others, 2007, p. 29), and the drainage area at the known location $\left(A_{K}\right)$ is $103 \mathrm{mi}^{2}$ (table 2). The exponent $(E X)$ for the 50-year flood discharge is 0.70 (table 6). $R_{U / K}$ (which equals $A_{U} / A_{K}$ ) is calculated to be 0.82 , which is greater than the upstream limit of the ratio of drainage areas, 0.40 ( $R_{U S}$ from table 6$)$, indicating that the installation of a streamgage station is not suggested. The 50-year flood discharge of the South Fork South Branch Potomac River just downstream from the confluence of George Run is calculated from equation 7 to be $16,200 \mathrm{ft}^{3} / \mathrm{s}$.

- Downstream from a streamgage station: The 2-year flood discharge (PK2, 50-percent AOP) for Sand Run just downstream from the confluence of Laurel Fork in Upshur County (Century 71/2-minute U.S. Geological Survey topographic map) and downstream from the streamgage station near Buckhannon (ID 90 and streamgage 03052500) can be calculated using equation 8. (No other streamgage station is present downstream from Sand Run near Buckhannon on the same stream.) The known 2-year flood discharge $\left(Q_{K}\right)$ at the Buckhannon streamgage station is $794 \mathrm{ft}^{3} / \mathrm{s}$ (the value for $Q_{w}$ from table 3). The drainage area at the unknown location $\left(A_{U}\right)$ is $27.56 \mathrm{mi}^{2}$ (Stewart and Mathes, 1995, p. 19), and the drainage area at the known location $\left(A_{K}\right)$ is $14.3 \mathrm{mi}^{2}$ (table 2). The result of the regional equation calculation at the unknown location $\left(Q_{U E}\right)$ is $1,260 \mathrm{ft}^{3} / \mathrm{s}$ (Central Mountains Region determined from fig. 4, equation from table 4) and for the known location $\left(Q_{K E}\right)$ is $708 \mathrm{ft}^{3} / \mathrm{s}$. $R_{U / K}$ (which equals $\left.A_{U} / A_{K}\right)$ was calculated to be 1.93 , which is less than the downstream limit of the ratio of drainage areas, 26.4 $\left(R_{D S}\right.$ from table 6$)$. The drainage areas are within the 
limits of the regional equation from 0.10 to $1,619 \mathrm{mi}^{2}$ (table 4), indicating that the procedure is valid and that the installation of a streamgage station is not suggested. The 2-year flood discharge of Sand Run just downstream from the confluence of Laurel Fork was calculated from equation 8 to be $1,340 \mathrm{ft}^{3} / \mathrm{s}$.

\section{- Between two streamgage stations on the same} stream: The 100-year flood discharge (PK100, 1-percent AOP) for the Greenbrier River just downstream from the confluence of Wolf Creek in Monroe County (Alderson 71/2-minute U.S. Geological Survey topographic map), downstream from the streamgage station at Alderson (ID 198 and streamgage 03183500), and upstream from the streamgage station at Hilldale (ID 201 and streamgage 03184000) can be calculated using equation 9 . The upstream 100year flood discharge $\left(Q_{U S}\right)$ at the Alderson streamgage station is $80,400 \mathrm{ft}^{3} / \mathrm{s}$, and the downstream 100 -year flood discharge $\left(Q_{D S}\right)$ at the Hilldale streamgage station is $85,400 \mathrm{ft}^{3} / \mathrm{s}$ (the values for $Q_{w}$ from table 3 ). The drainage area at the unknown location $\left(A_{U}\right)$ is 1,535.79 $\mathrm{mi}^{2}$ (Mathes and others, 1982, p. 55), the upstream drainage area at the Alderson streamgage station $\left(A_{U S}\right)$ is $1,364 \mathrm{mi}^{2}$ (table 2), and the downstream drainage area at the Hilldale gaging station $\left(A_{D S}\right)$ is $1,619 \mathrm{mi}^{2} . \mathrm{R}_{U / K}$ (which equals $A_{U} / A_{K}$ ) at the upstream location was calculated to be 1.13 , which is less than the downstream limit of the ratio of drainage areas, 26.4 ( $R_{D S}$ from table 6 ). $R_{U / K}$ at the downstream location was calculated to be 0.95 , which is greater than the upstream limit of the ratio of drainage areas, 0.40 ( $R_{U S}$ table 6), indicating that the procedure is valid and that installation of a streamgage is not suggested. The 100-year flood discharge of the Greenbrier River just downstream from the confluence of Wolf Creek was calculated from equation 9 to be $83,800 \mathrm{ft}^{3} / \mathrm{s}$.

- Not on the same stream as a streamgage station: The 10-year flood discharge (PK10, 10-percent AOP) for Fishing Creek just downstream from the confluence of North and South Forks of Fishing Creek in Wetzel County (Pine Grove 71/2-minute U.S. Geological Survey topographic map) can be calculated from the regional equation. (There are no streamgage stations on Fishing Creek or South Fork Fishing Creek that could have been on the same stream.) The streams are in the Western Plateaus Region (fig. 4), and the drainage area is $113.92 \mathrm{mi}^{2}$ (Wiley, 1997, page 30). The drainage area is within the limits of the regional equation from 0.13 to $1,516 \mathrm{mi}^{2}$ (table 4), indicating that the procedure is valid, but that installation of a streamgage station could improve the estimate. The 10-year flood discharge was calculated from the regression equation for the Western Plateaus Region (table 4) to be $8,000 \mathrm{ft}^{3} / \mathrm{s}$.

\section{Limitations of Procedures for Estimating Flood- Frequency Discharges}

Procedures developed in this study are applicable only to rural, unregulated streams located within the boundaries of West Virginia. Procedures also are limited to the range of drainage areas used to develop the equations - from 0.21 to $1,461 \mathrm{mi}^{2}$ in the Eastern Panhandle Region, from 0.10 to $1,619 \mathrm{mi}^{2}$ in the Central Mountains Region, and from 0.13 to $1,516 \mathrm{mi}^{2}$ in the Western Plateaus Region. The procedures are not meant to be applied to urban areas with paved surfaces, concrete channels, or culverts that substantially increase runoff or decrease infiltration. The procedures are not meant to be applied to streams regulated by dams or with large lakes and ponds that substantially retain runoff. Procedures are not applicable to heavily mined areas if excessive runoff is diverted into or outside the basin, retained along strip benches, or retained underground. Procedures are not applicable to karst areas if excessive runoff is diverted into, outside, or deep within the basin through solution channels or other cavities in carbonate (limestone and dolomite) rocks. Jones (1997) describes the locations of karst areas in eastern counties of West Virginia, including parts of Monongalia, Preston, Barbour, Tucker, Grant, Mineral, Hardy, Hampshire, Morgan, Berkeley, Jefferson, Randolph, Pendleton, Pocahontas, Greenbrier, Summers, Monroe, and Mercer (counties are shown in fig. 4).

\section{Summary}

Flood-frequency discharges were determined for 290 streamgage stations on rural, unregulated streams in West Virginia and adjacent states that have a minimum of 9 years of record through the 2006 or 2007 water year. This study was conducted by the USGS, in cooperation with the West Virginia Department of Transportation, Division of Highways. West Virginia skew coefficients were used instead of the United States skew coefficients used in previous studies in West Virginia. Flood-frequency discharges and skew coefficients for stations in adjacent states are applicable only for determining estimates in West Virginia and do not supersede values used in the adjacent states.

The results of a correlation analysis of $36 \log _{10}$-transformed basin characteristics available for the 290 streamgage stations reduced the number of characteristics to 32 for consideration as independent variables in the regression analysis. Elongation ratio (ER), rotundity of basin (RB), channel maintenance $(\mathrm{CM})$, and basin width $(\mathrm{BW})$ were removed from consideration as independent variables because the Pearson's coefficient was equal to 1 (singularity) for this group of basin characteristics.

Regression analysis was conducted using $\log _{10}$-transformed flood-frequency discharges as dependent variables and $\log _{10}$-transformed basin characteristics as independent 
variables for 246 streamflow stations. Forty-four streamflow stations were excluded from the analysis because the (1) peak data were used to lengthen records for other nearby streamgage stations, (2) station is located in a karst area, (3) plot of the regression residual indicated the station was not representative of West Virginia, and (4) station has a large drainage area and leveraged the regression equation, affecting estimates for small drainage areas. Residuals from multiple and simple least-squares regression models of the 100-year (1-percent AOP) flood discharge with independent variables describing the basin characteristics were used to determine drainage area as the only significant independent variable and to delineate boundaries of three regions in West VirginiaEastern Panhandle, Central Mountains, and Western Plateaus. Regional equations for the 1.1- (90-percent AOP), 1.5-

(67-percent AOP), 2- (50-percent AOP), 5- (20-percent AOP), 10- (10-percent AOP), 25- (4-percent AOP), 50- (2-percent AOP), 100- (1-percent AOP), 200- (0.5-percent AOP), and 500 -year (0.2-percent AOP) flood discharges were determined by executing a generalized least-squares regression model. Drainage area was the only significant independent variable determined for all equations in all regions.

The 246 streamgage stations were reduced to 125 for consideration in the trend analysis. For the trend analysis, streamgage stations with a minimum of 30 years of record were considered in order to eliminate effects that might be due to climate variability. Twelve streamgage stations indicated a trend, twice as many as would be expected by chance, but the stations were about equally divided between those having a positive trend and those having a negative trend. No significance was determined for the streamgage stations having a trend.

The accuracy of estimating equations was quantified by measuring the average prediction error and equivalent years of record. The average prediction error ranged from 21.7 to 56.3 percent, and the equivalent years of record ranged from 2.0 to 70.9 years.

Procedures for estimating flood-frequency discharges at a streamgage station and at an ungaged location are presented in the text of this report. The procedures for an ungaged location include a combination of (1) estimates based on drainage-area ratios between stations and ungaged locations on the same stream and (2) estimates from regional equations. Examples of the procedures are presented in the text.

Equations developed in this study are applicable only to rural, unregulated streams located within the boundaries of West Virginia. Equation application is limited to the range of drainage areas used in equation development-from 0.21 to $1,461 \mathrm{mi}^{2}$ in the Eastern Panhandle Region, from 0.10 to $1,619 \mathrm{mi}^{2}$ in the Central Mountains Region, and from 0.13 to $1,516 \mathrm{mi}^{2}$ in the Western Plateaus Region. The authors suggest using caution in evaluating the results if the equations are applied to heavily mined or karst areas.

\section{References Cited}

Atkins, J.T., Jr., Wiley, J.B., and Paybins, K.S., 2009, Generalized skew coefficients of annual peak flows for rural, unregulated streams in West Virginia: U.S. Geological Survey Open-File Report 2008-1304, 13 p.

Barnes, H.H., Jr., 1964, Floods of March 1963, Alabama to West Virginia: U.S. Geological Survey Open-File Report 63-8, $44 \mathrm{p}$.

Benson, M.A., 1962, Factors influencing the occurrence of floods in a humid region of diverse terrain: U.S. Geological Survey Water-Supply Paper 1580-B, 64 p.

Bisese, J.A., 1995, Methods for estimating magnitude and frequency of peak discharges of rural, unregulated streams in Virginia: U.S. Geological Survey Water-Resources Investigations Report 94-4148, $70 \mathrm{p}$.

Carpenter, D.H., 1990, Floods in West Virginia, Virginia, Pennsylvania, and Maryland, November 1985: U.S. Geological Survey Water-Resources Investigations Report 88-4213, 86 p.

Dawdy, D.R., Lichty, R.W., and Bergmann, J.M., 1972, A rainfall-runoff simulation model for estimation of flood peaks for small drainage basins: U.S. Geological Survey Professional Paper 506-B, 28 p.

Dillow, J.A., 1996, Technique for estimating magnitude and frequency of peak flows in Maryland: U.S. Geological Survey Water-Resources Investigations Report 95-4154, 55 p.

Doll, W.C., Meyer, Gerald, and Archer, R.J., 1963, Water Resources of West Virginia: Charleston, WV, West Virginia Department of Natural Resources, Division of Water Resources, $134 \mathrm{p}$.

Fenneman, N.M., 1938, Physiography of Eastern United States: New York, McGraw-Hill, 714 p.

Flynn, K.M., Kirby, W.H., and Hummel, P.R., 2006, User's manual for program PeakFQ annual flood-frequency analysis using Bulletin 17B guidelines: U.S. Geological Survey Techniques and Methods bk 4, chap. B4, 42 p.

Flynn, R.H., 2003, Development of regression equations to estimate flow durations and low-flow-frequency statistics in New Hampshire streams: U.S. Geological Survey WaterResources Investigations Report 02-4298, 66 p.

Frye, P.M., and Runner, G.S., 1969, Procedure for estimating magnitude and frequency of floods in West Virginia: West Virginia State Road Commission design directive, $10 \mathrm{p}$.

Frye, P.M., and Runner, G.S., 1970, A proposed streamflow data program for West Virginia: U.S. Geological Survey Open-File Report, 38 p. 
Frye, P.M., and Runner, G.S., 1971, A preliminary report on small streams flood frequency in West Virginia: West Virginia Department of Highways design directive, $9 \mathrm{p}$.

Grover, N.C., 1937, The floods of March 1936, Part 3, Potomac, James, and upper Ohio Rivers: U.S. Geological Survey Water-Supply Paper 800, 351 p.

Hardison, C.H., 1969, Accuracy of streamflow characteristics: U.S. Geological Survey Professional Paper 650-D, p. D210-D214.

Hardison, C.H., 1971, Predictive error of streamflow characteristics at ungaged sites: U.S. Geological Survey Professional Paper 750-C, p. 228-236.

Hayes, D.C., 1991, Low-flow characteristics of streams in Virginia: U.S. Geological Survey Water-Supply Paper 2374, $69 \mathrm{p}$.

Helsel, D.R., and Hirsch, R.M., 2002, Statistical methods in water resources: U.S. Geological Survey Techniques of Water-Resources Investigations Report, bk 4, chap. A3, 510 p.

Hirsch, R.M., Slack, J.R., and Smith, R.A., 1982, Techniques of trend analysis for monthly water quality data: Water Resources Research, v. 18, no. 1, p. 107-121.

Hodge, S.A., and Tasker, G.D., 1995, Magnitude and frequency of floods in Arkansas: U.S. Geological Survey Water-Resources Investigations Report 95-4224, 52 p.

Hodgkins, G.A., and Martin, G.R., 2003, Estimating the magnitude and frequency of peak flows for streams in Kentucky for selected recurrence intervals: U.S. Geological Survey Water-Resources Investigations Report 03-4180, 68 p.

Insightful Corporation, 2005, S-PLUS 7.0 Professional edition software for Windows: Seattle, Washington, Insightful Corporation.

Interagency Advisory Committee on Water Data, 1976, Guidelines for determining flood flow frequency: Water Resources Council Bulletin 17, 26 p.

Interagency Advisory Committee on Water Data, 1982, Guidelines for determining flood flow frequency: Water Resources Council Bulletin 17B, 28 p.

Jones, W.K., 1997, Karst hydrology of West Virginia: Charles Town, WV, Karst Waters Institute, Inc., Special Publication 4, $111 \mathrm{p}$.

Kendall, M.G., 1975, Rank correlation methods (4th ed.): London, Charles Griffin, 202 p.

Kirby, W., 1980, Computer routines for probability distributions, random numbers, and related functions: U.S. Geological Survey Open-File Report 80-448, 61 p.
Koltun, G.F., 2003, Techniques for estimating flood-peak discharges of rural, unregulated streams in Ohio: U.S. Geological Survey Water-Resources Investigations Report 03-4164, $75 \mathrm{p}$.

Lescinsky, J.B., 1987, Flood of November 1985 in West Virginia, Pennsylvania, Maryland, and Virginia: U.S. Geological Survey Open-File Report 86-486, 33 p.

Lumb, A.M., Kittle, J.L., Jr., and Flynn, K.M., 1990, Users manual for ANNIE, computer program for interactive hydrologic analysis and data management: U.S. Geological Survey Water-Resources Investigations Report 89-4080, $236 \mathrm{p}$.

Mathes, M.V, Jr., 1977, Drainage areas of the Guyandotte River Basin, West Virginia: U.S. Geological Survey OpenFile Report 77-801, 56 p.

Mathes, M.V., Kirby, J.R., Payne, D.D., and Shultz, R.A., 1982, Drainage areas of the Kanawha River Basin, West Virginia: U.S. Geological Survey Open-File Report 82-351, $222 \mathrm{p}$.

National Oceanic and Atmospheric Administration, 2006a, Climate of West Virginia, accessed September 30, 2006, at http://cdo.ncdc.noaa.gov/climatenormals/clim60/states/ Clim_WV_01.pdf.

National Oceanic and Atmospheric Administration, 2006b, Total precipitation in inches by month for climate divisions, accessed September 30, 2006, at http://www.cdc.noaa.gov/ USclimate/pcp.state.19712000.climo.html.

Natural Resources Conservation Service, 2006, West Virginia Precipitation data/maps, accessed September 30, 2006, at http://www.ncgc.nrcs.usda.gov/products/datasets/climate/ data/precipitation-state/wv.html.

Paybins, K.S., 2008, Basin characteristics for selected streamflow-gaging stations in and near West Virginia: U.S. Geological Survey Open-File Report 2008-1087, 9 p. (Also available at http://pubs.er.usgs.gov/usgspubs/ofr/ ofr20081087.)

Preston, J.S., and Mathes, M.V., 1984, Stream drainage areas for the Little Kanawha River Basin, West Virginia: U.S. Geological Survey Open-File Report 84-861, 171 p.

Ries, K.G., III, and Friesz, P.J., 2000, Methods for estimating low-flow statistics for Massachusetts streams: U.S. Geological Survey Water-Resources Investigations Report 00-4135, $81 \mathrm{p}$.

Runner, G.S., 1979, Flood of April 1977 on the Tug Fork, Matewan to Williamson, West Virginia and Kentucky: U.S. Geological Survey Hydrologic Investigations Atlas HA-588, scale 1:12,000. 
Runner, G.S., 1980a, Technique for estimating magnitude and frequency of floods in West Virginia: U.S. Geological Survey Open-File Report 80-1218, 44 p.

Runner, G.S., 1980b, Hydrologic data for Runoff studies on small drainage areas, West Virginia Department of Highways Research Project 16: U.S. Geological Survey OpenFile Report 80-560, 169 p.

Runner, G.S., and Chin, E.H., 1980, Flood of April 1977 in the Appalachian region of Kentucky, Tennessee, Virginia, and West Virginia: U.S. Geological Survey Professional Paper 1098,43 p.

Speer, P.R., and Gamble, C.R., 1965, Magnitude and frequency of floods in the United States, Part 3-A, Ohio River basin except Cumberland and Tennessee River basins: U.S. Geological Survey Water-Supply Paper 1675, 630 p.

Stedinger, J.R., and Tasker, G.D., 1985, Regional hydrologic analysis 1: ordinary, weighted, and generalized least squares compared: Water Resources Research, v. 21, no. 9, p. 1421-1432.

Stewart, D.K., and Mathes, M.V., 1995, Drainage areas of the Monongahela River Basin, West Virginia: U.S. Geological Survey Open-File Report 95-170, 79 p.

Stuckey, M.H., and Reed, L.A., 2000, Techniques for estimating magnitude and frequency of peak flows for Pennsylvania streams: U.S. Geological Survey Water-Resources Investigations Report 00-4189, 43 p.

Tasker, G.D., and Stedinger, J.R., 1989, An operational GLS model for hydrologic regression: Journal of Hydrology, v. 111 , p. $361-375$.

Tice, R.H., 1968, Magnitude and frequency of floods in the United States, Part 1-B, North Atlantic Slope Basins, New York to York River: U.S. Geological Survey Water-Supply Paper 1672, 585 p.

U.S. Geological Survey, 1990, National water summary 1987-Hydrologic events and water supply and use: U.S. Geological Survey Water-Supply Paper 2350, 553 p.
U.S. Geological Survey, 1991, National water summary 1988-89-Hydrologic events and floods and droughts: U.S. Geological Survey Water-Supply Paper 2375, 591 p.

U.S. Geological Survey, 2001, Water Resources Applications Software: LIB3.2, revised June 29, 1998, accessed November 2001, at http://water.usgs.gov/software/lib.html/.

U.S. Geological Survey, 2005, Streamflow trends in the United States: U.S. Geological Survey Fact Sheet FS2005-3017, $4 \mathrm{p}$.

U.S. Geological Survey, 2006, The National Map, accessed September 30, 2006, at http://nationalmap.gov.

Wiley, J.B., 1997, Drainage areas of West Virginia streams tributary to the Ohio River: U.S. Geological Survey OpenFile Report 97-231, 70 p.

Wiley, J.B., 2008, Estimating selected annual streamflow statistics representative of 1930-2002 in West Virginia: U.S. Geological Survey Scientific Investigations Report 2008-5105, 24 p.

Wiley, J.B., Atkins, J.T., Jr., and Newell, D.A., 2002, Estimating the magnitude of annual peak discharges with recurrence intervals between 1.1 and 3.0 years for rural, unregulated streams in West Virginia: U.S. Geological Survey Water-Resources Investigations Report 02-4164, 73 p.

Wiley, J.B., Atkins, J.T., Jr., and Tasker, G.D., 2000, Estimating magnitude and frequency of peak discharges for rural, unregulated streams in West Virginia: U.S. Geological Survey Water-Resources Investigations Report 00-4080, 93 p.

Wiley, J.B., Hunt, M.L., and Stewart, D.K., 2007, Drainage areas of the Potomac River Basin, West Virginia: U.S. Geological Survey Open-File Report 95-292 (3d ed.), 60 p.

Wilson, M.W., 1979, Drainage areas of the Twelvepole Creek Basin, West Virginia; Big Sandy River Basin, West Virginia; Tug Fork Basin, Virginia, Kentucky, West Virginia: U.S. Geological Survey Open-File Report 79-746, 49 p. 


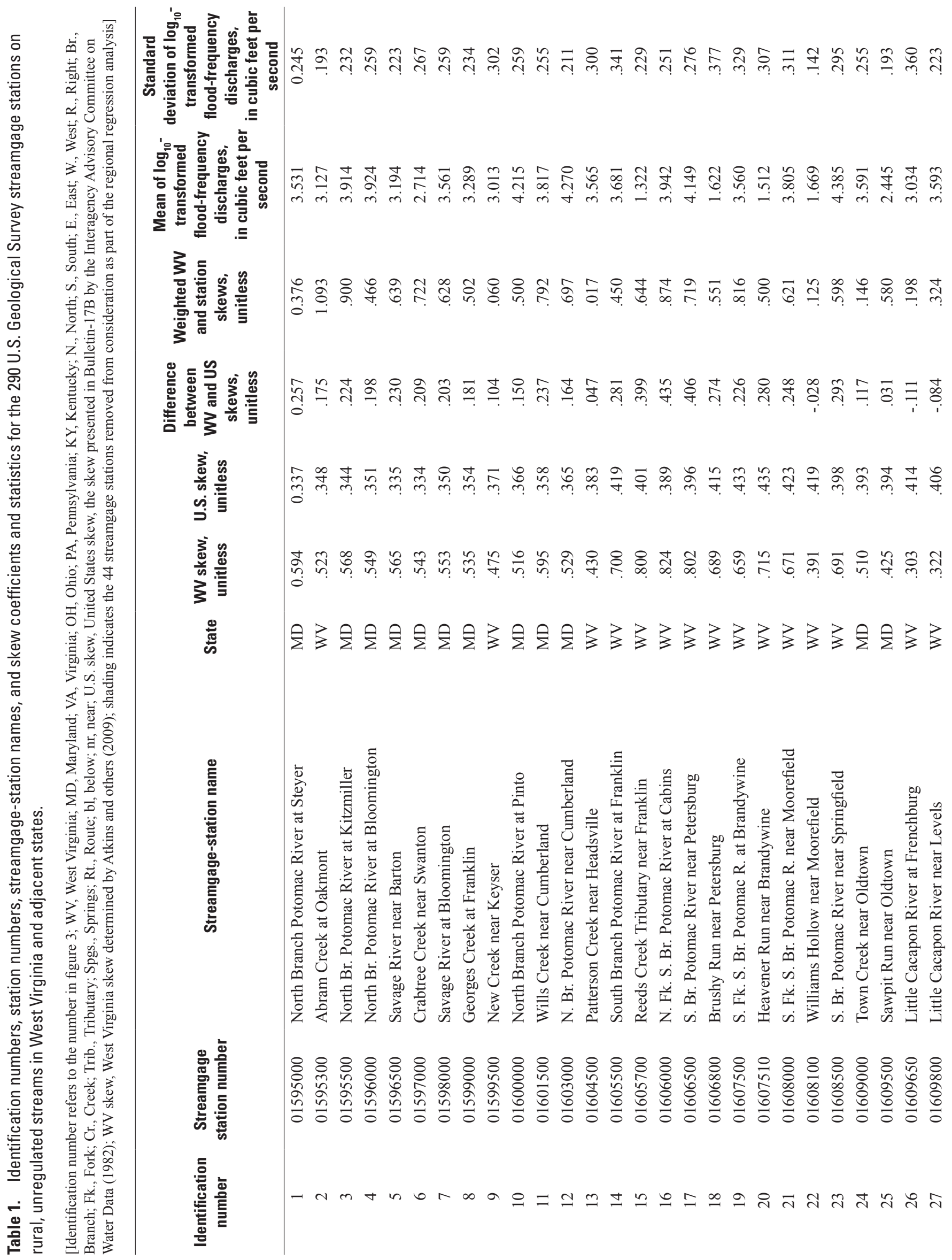




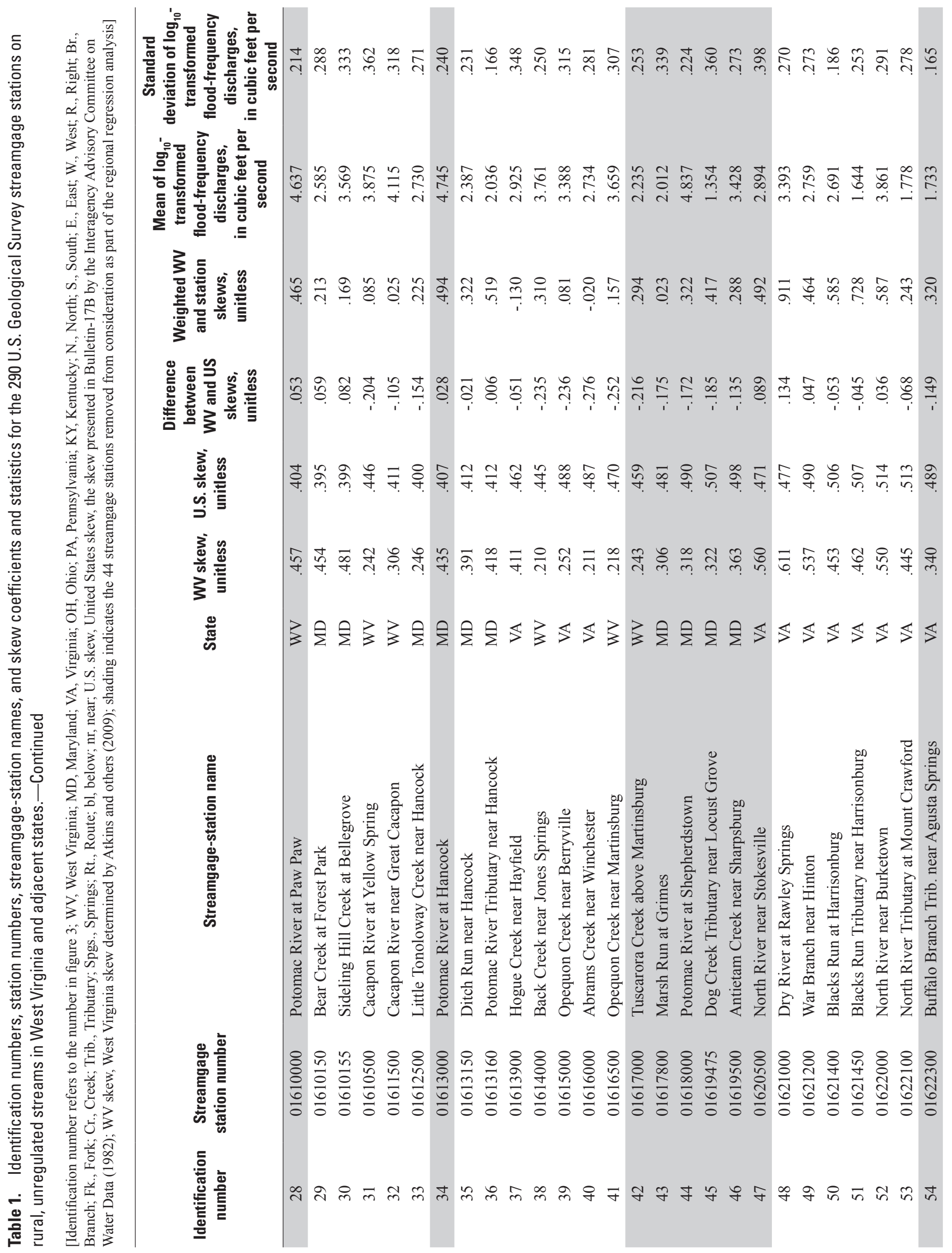




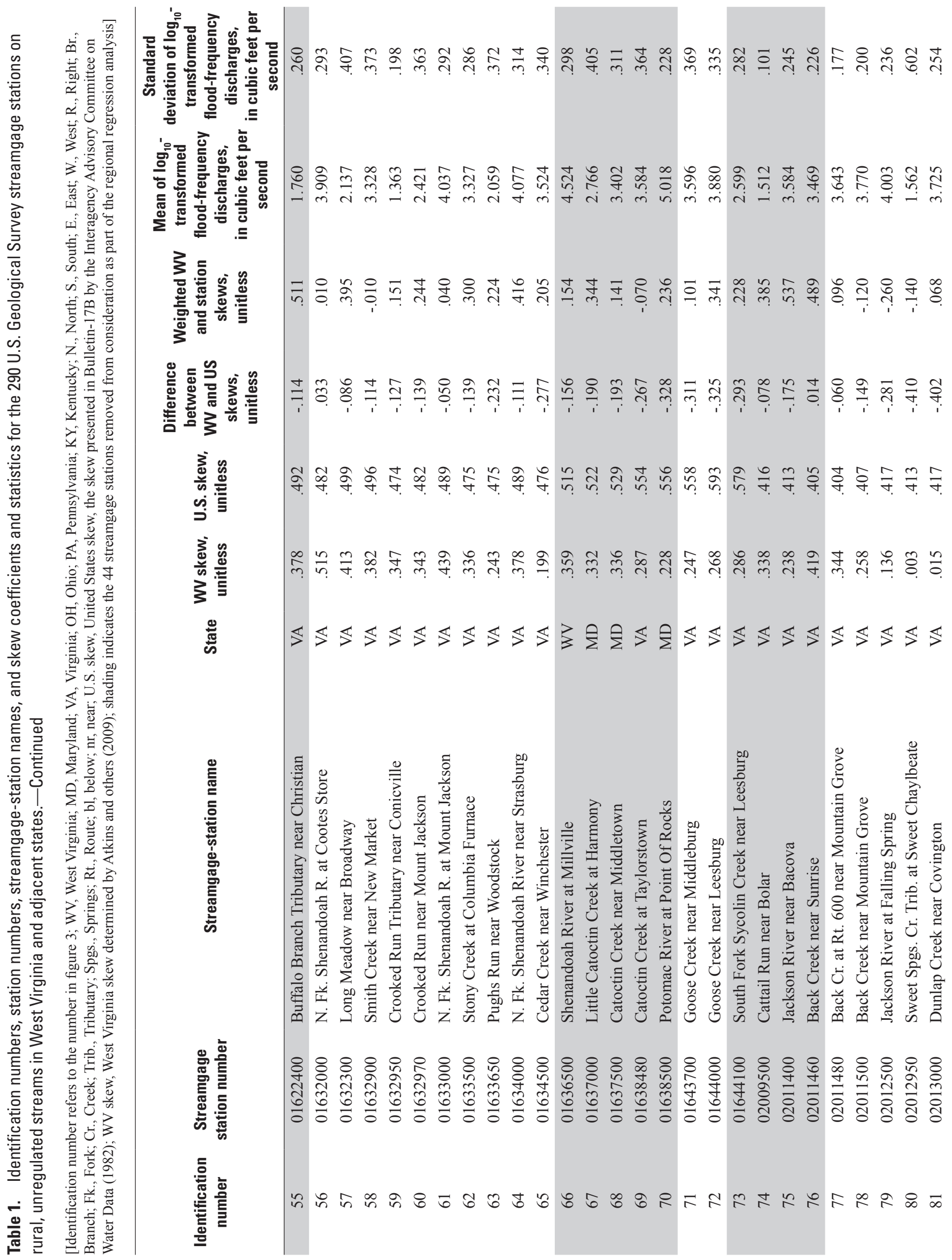




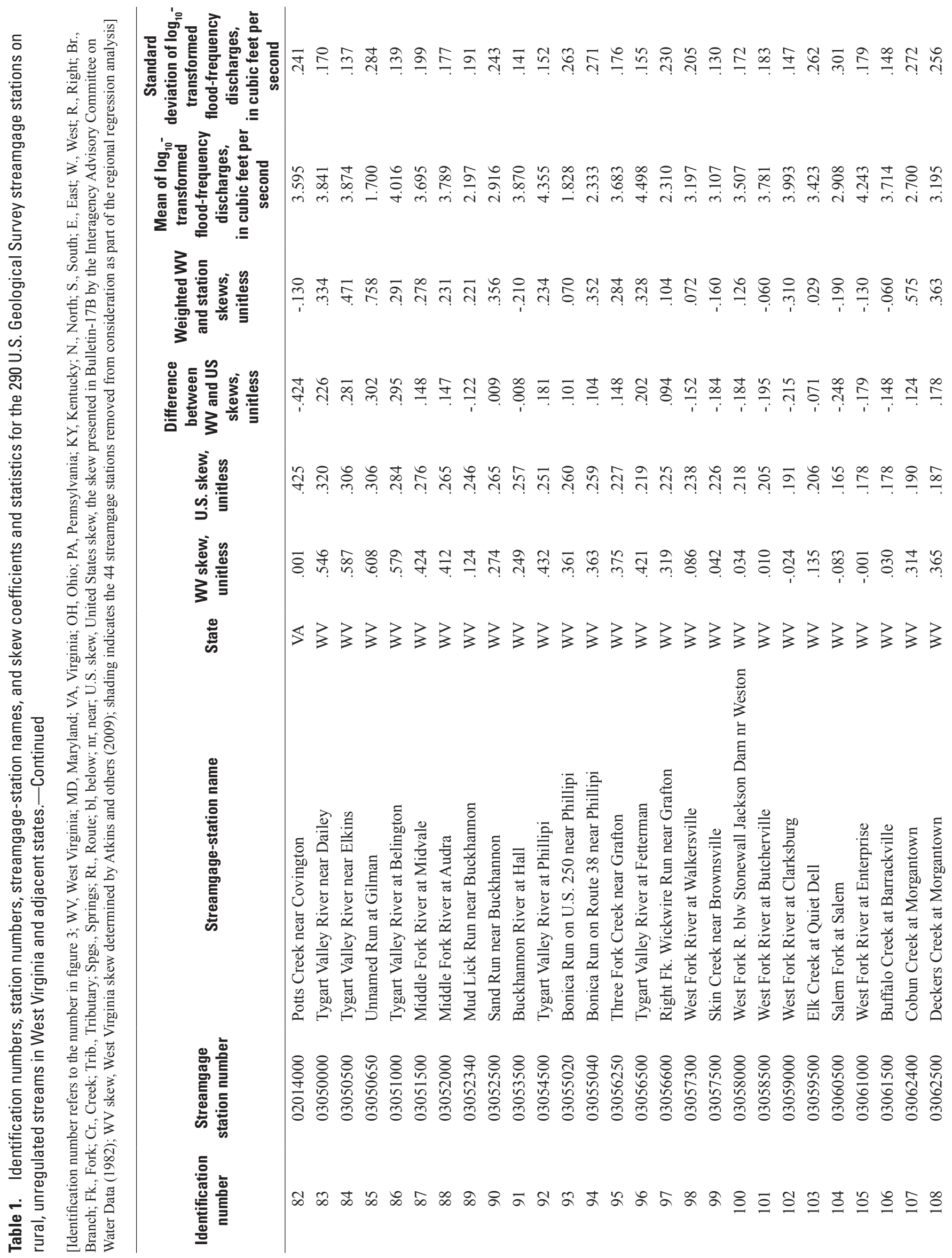




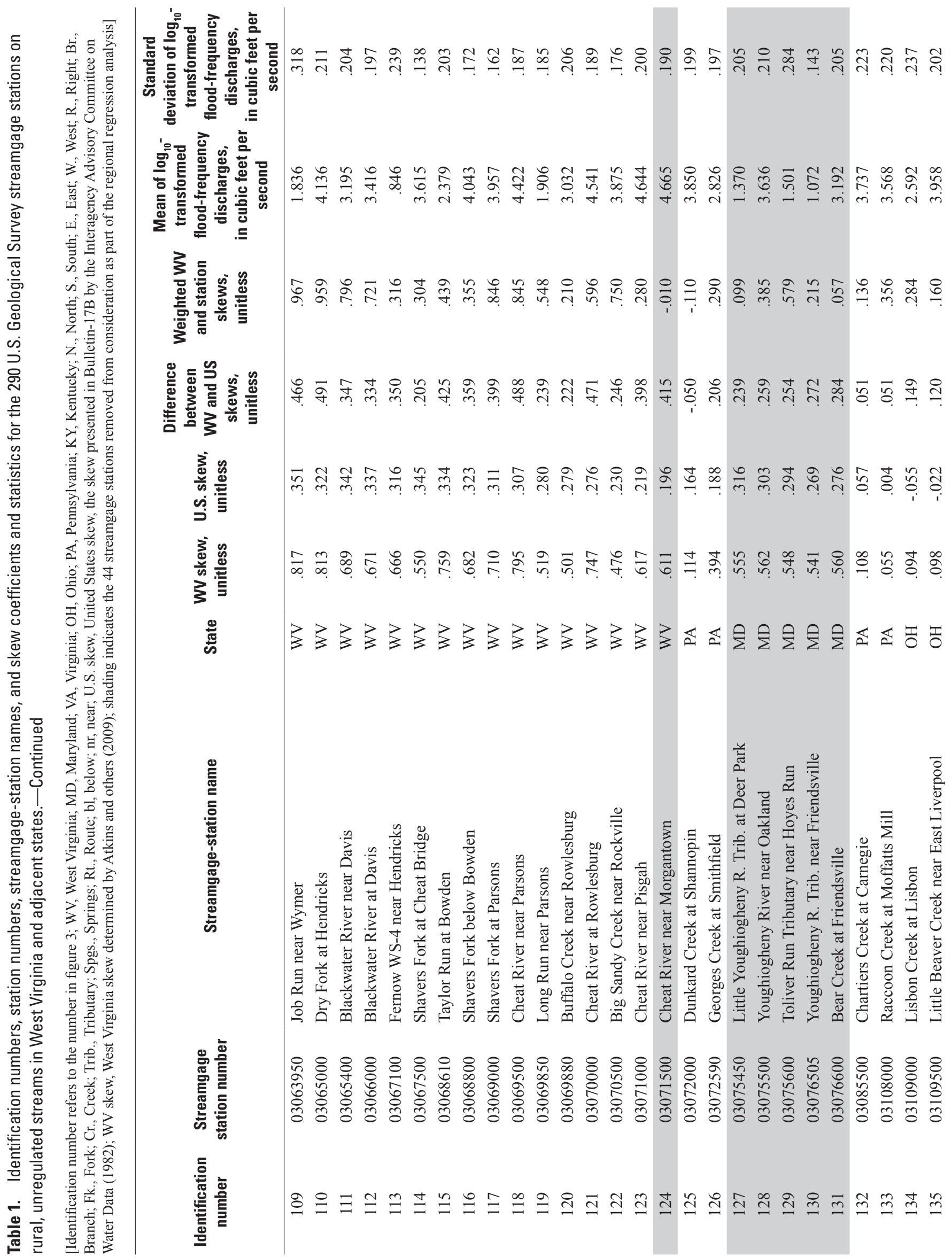




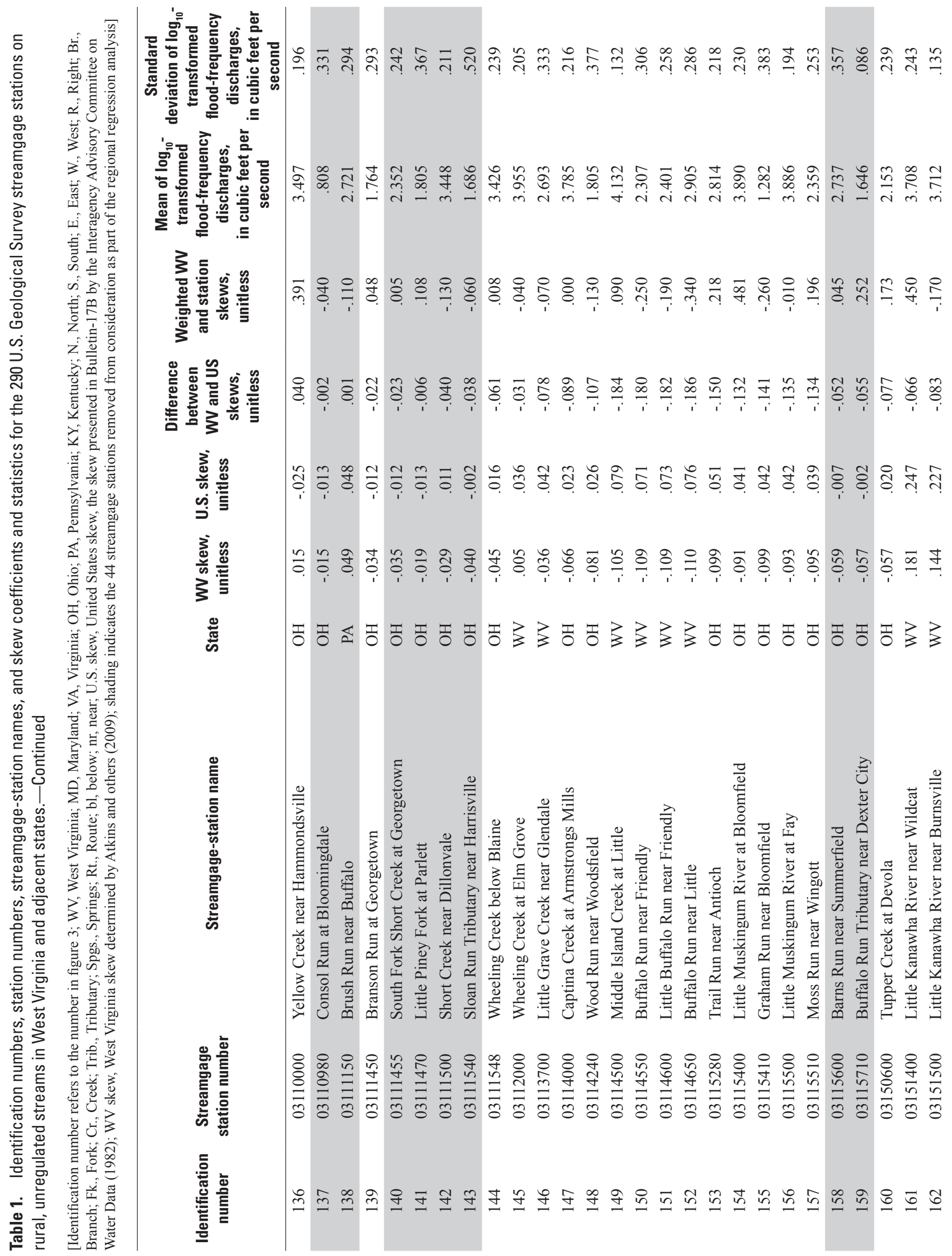




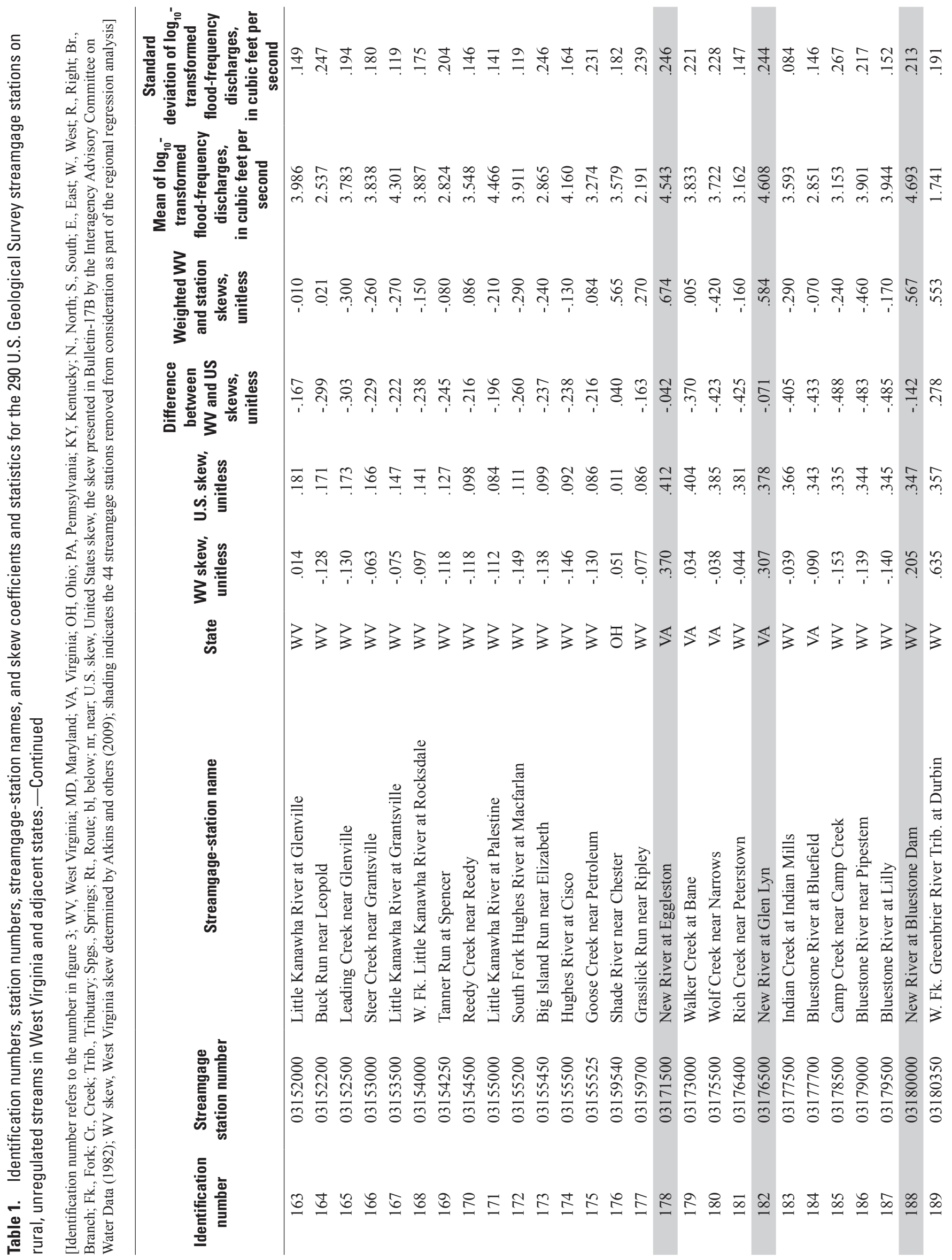




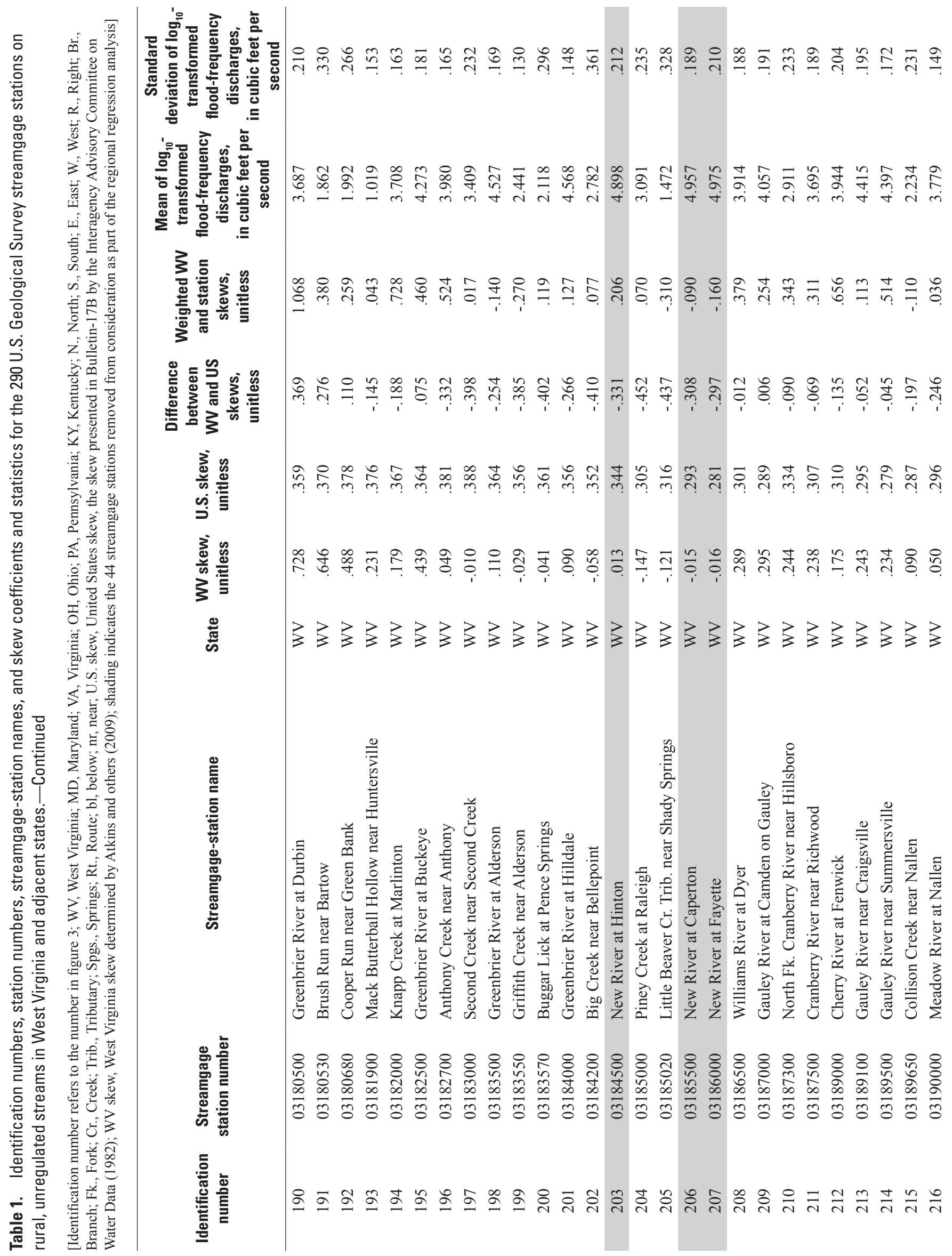




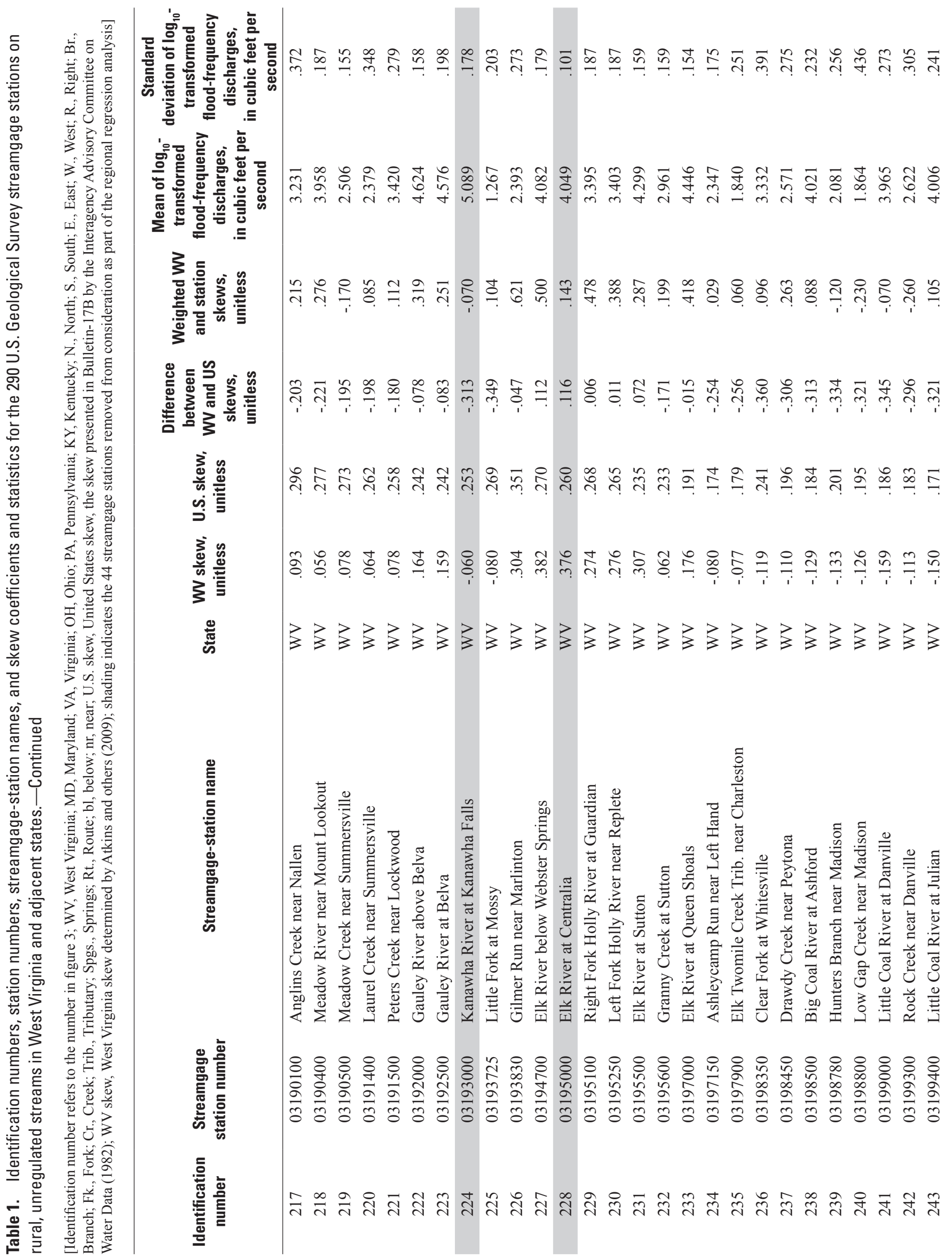




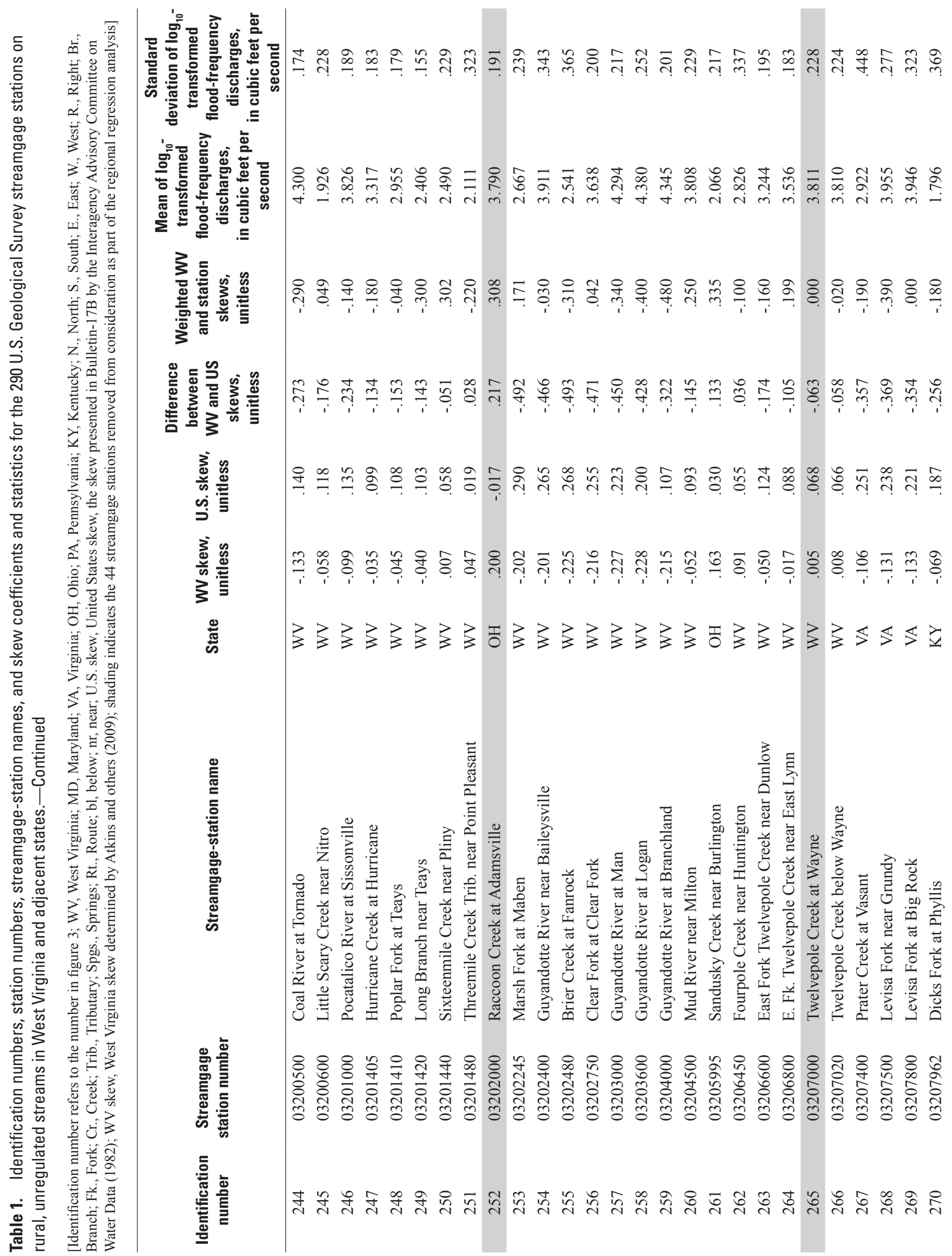




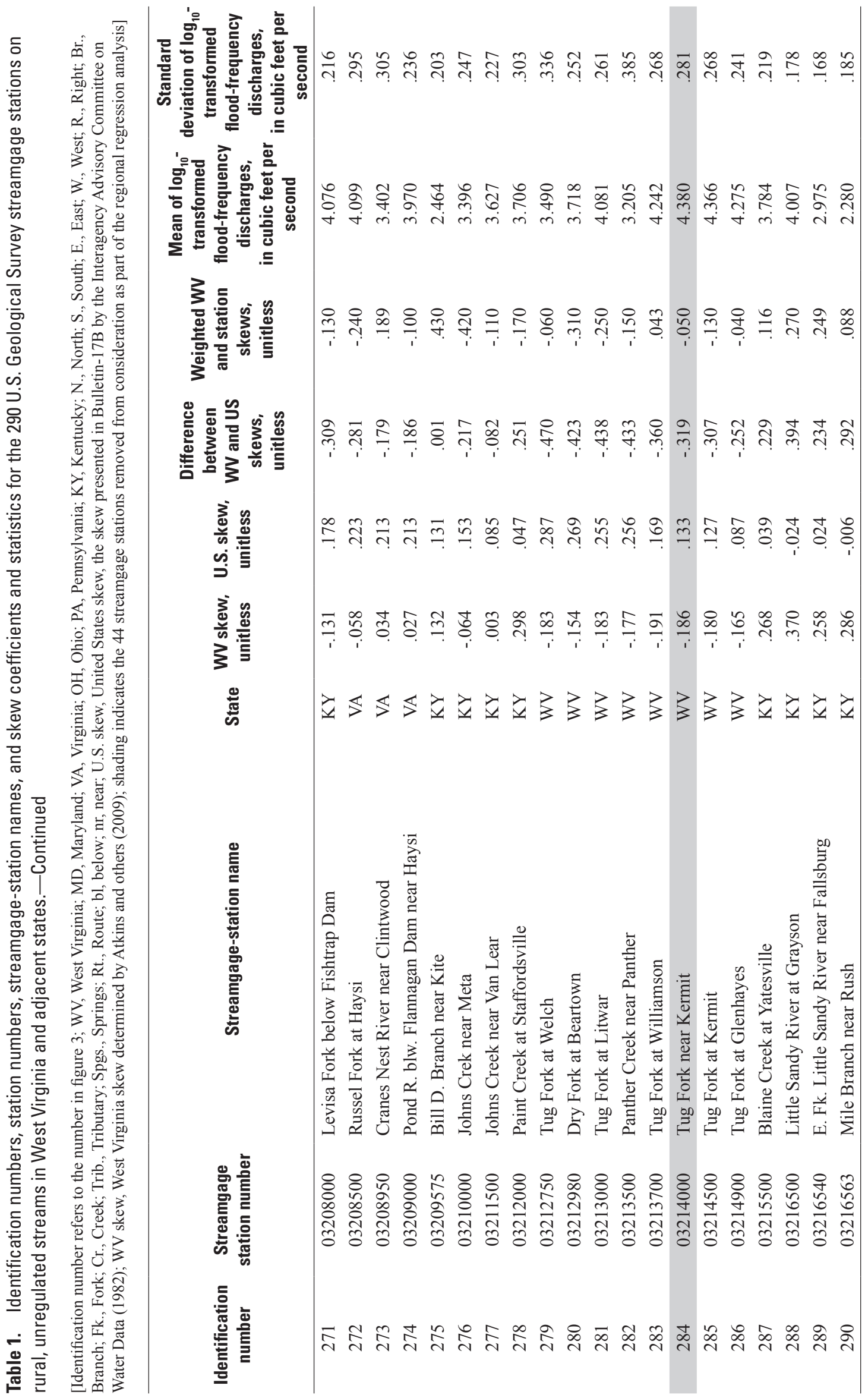




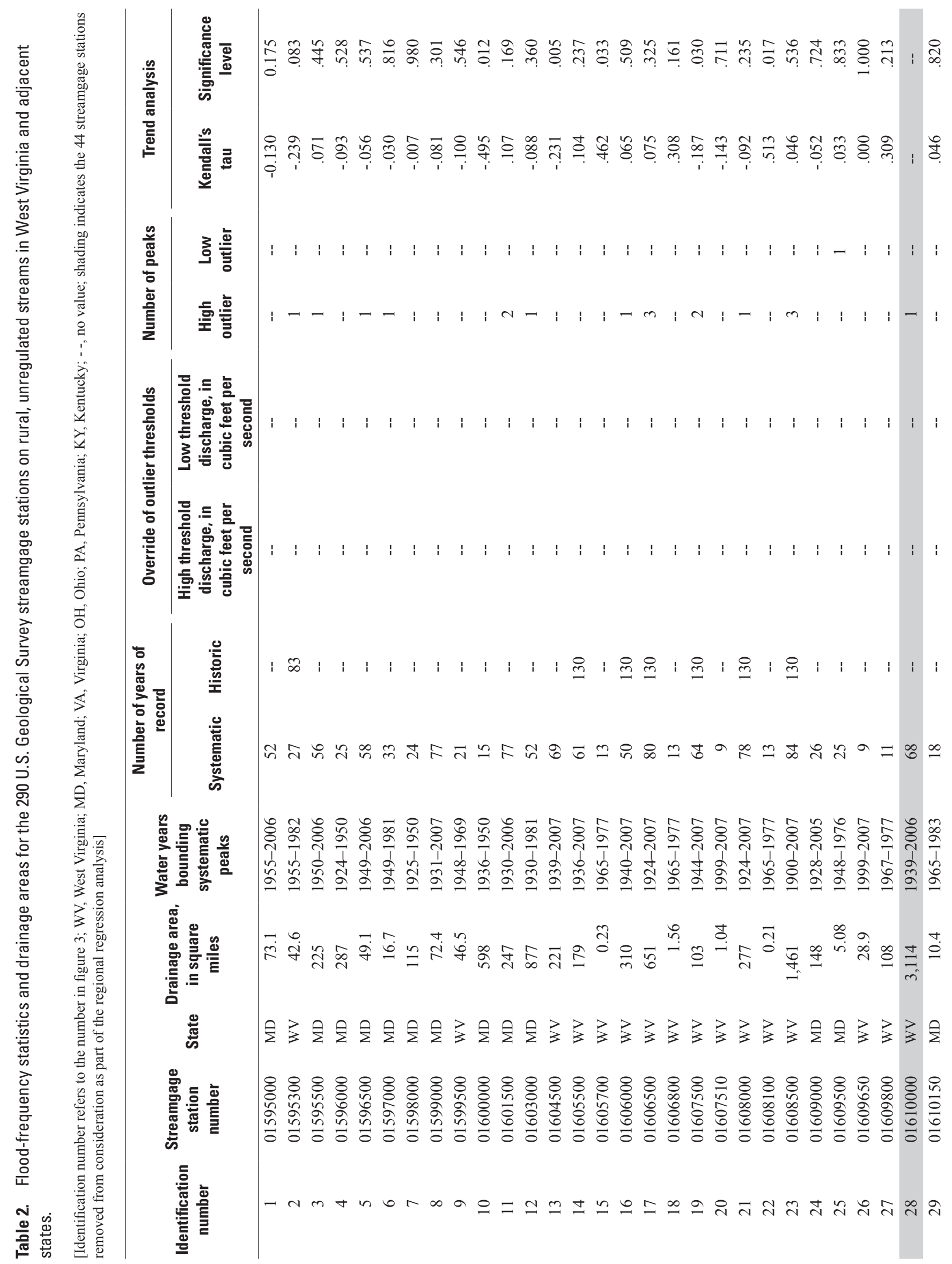




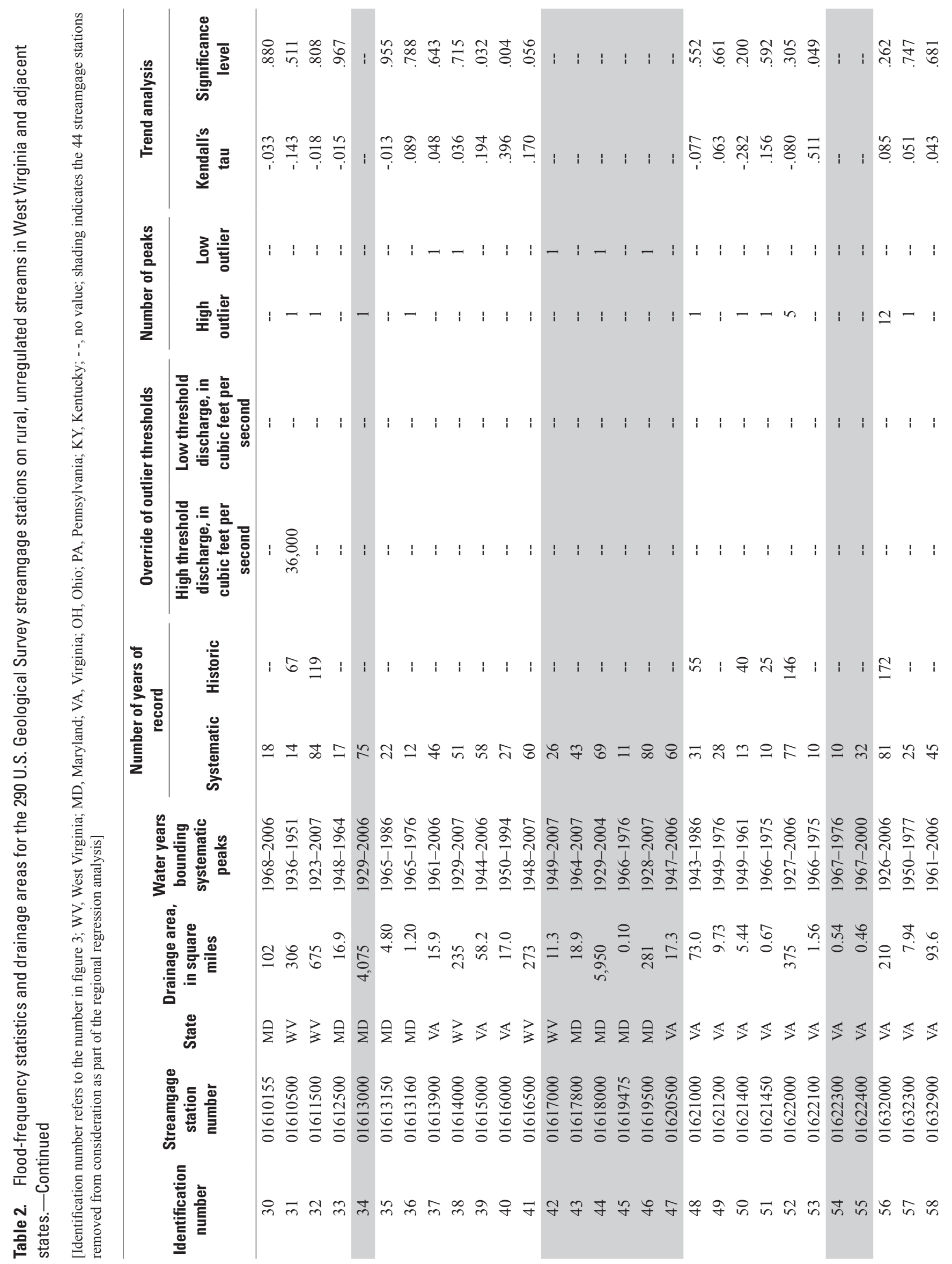




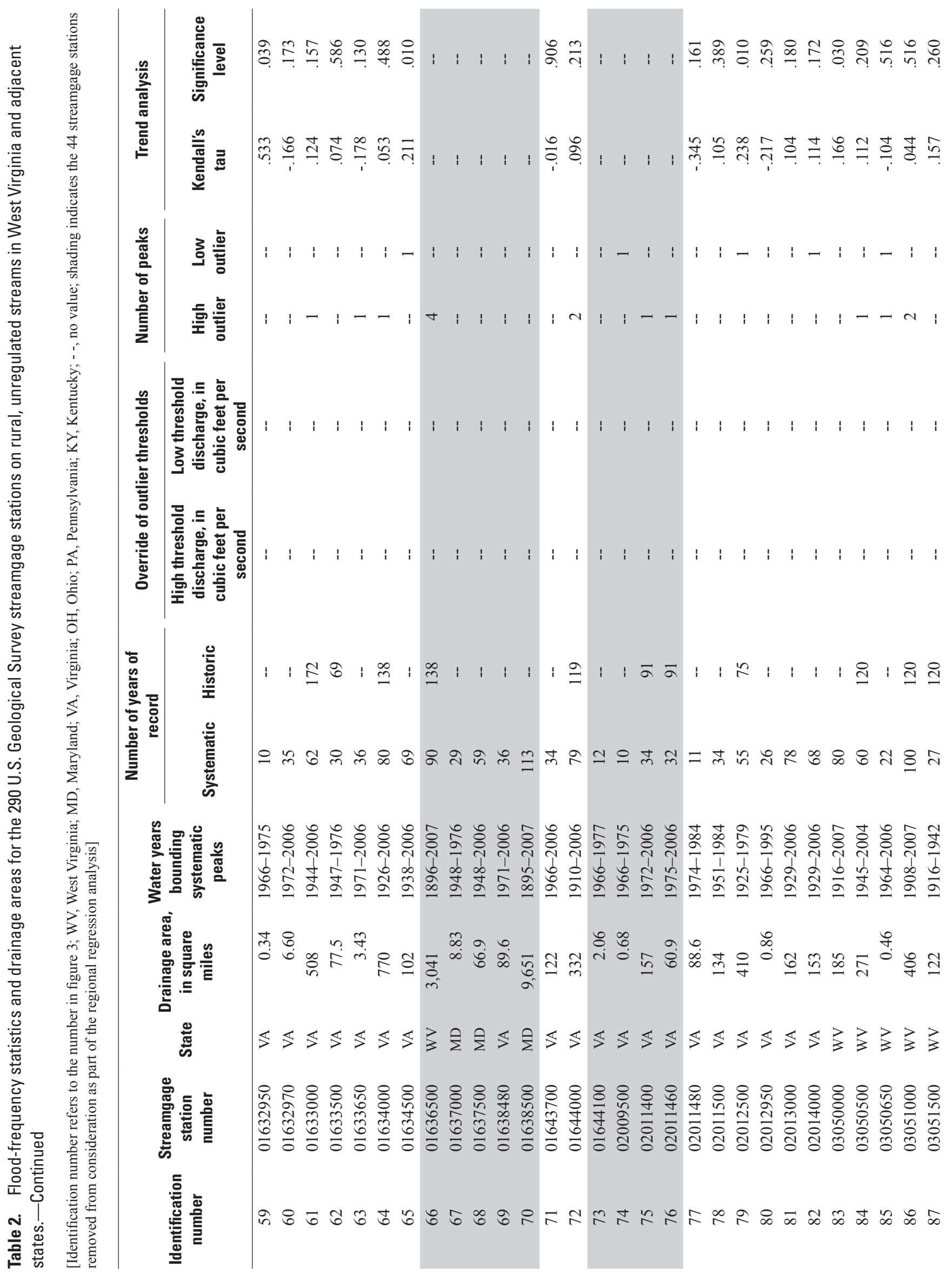




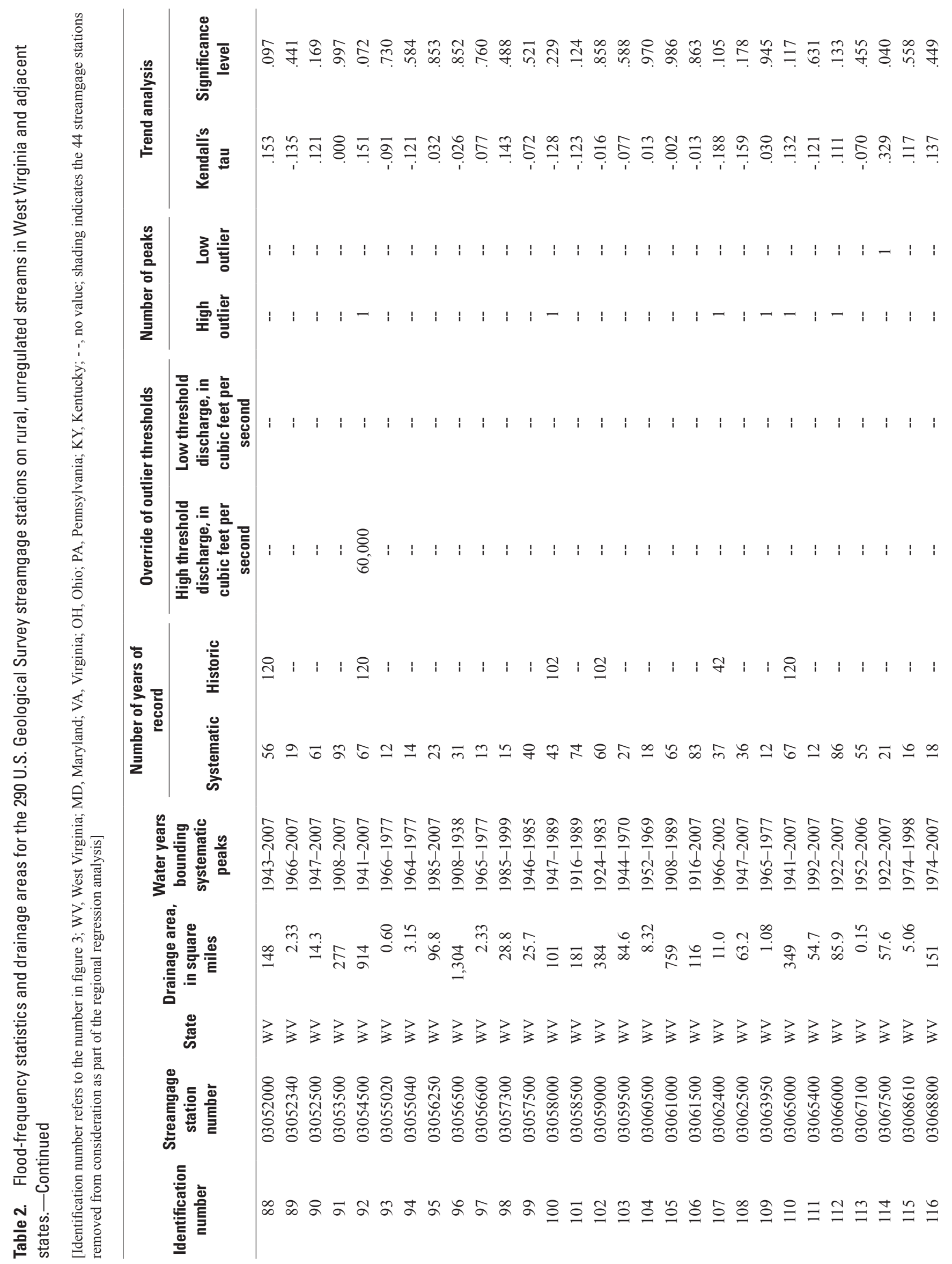




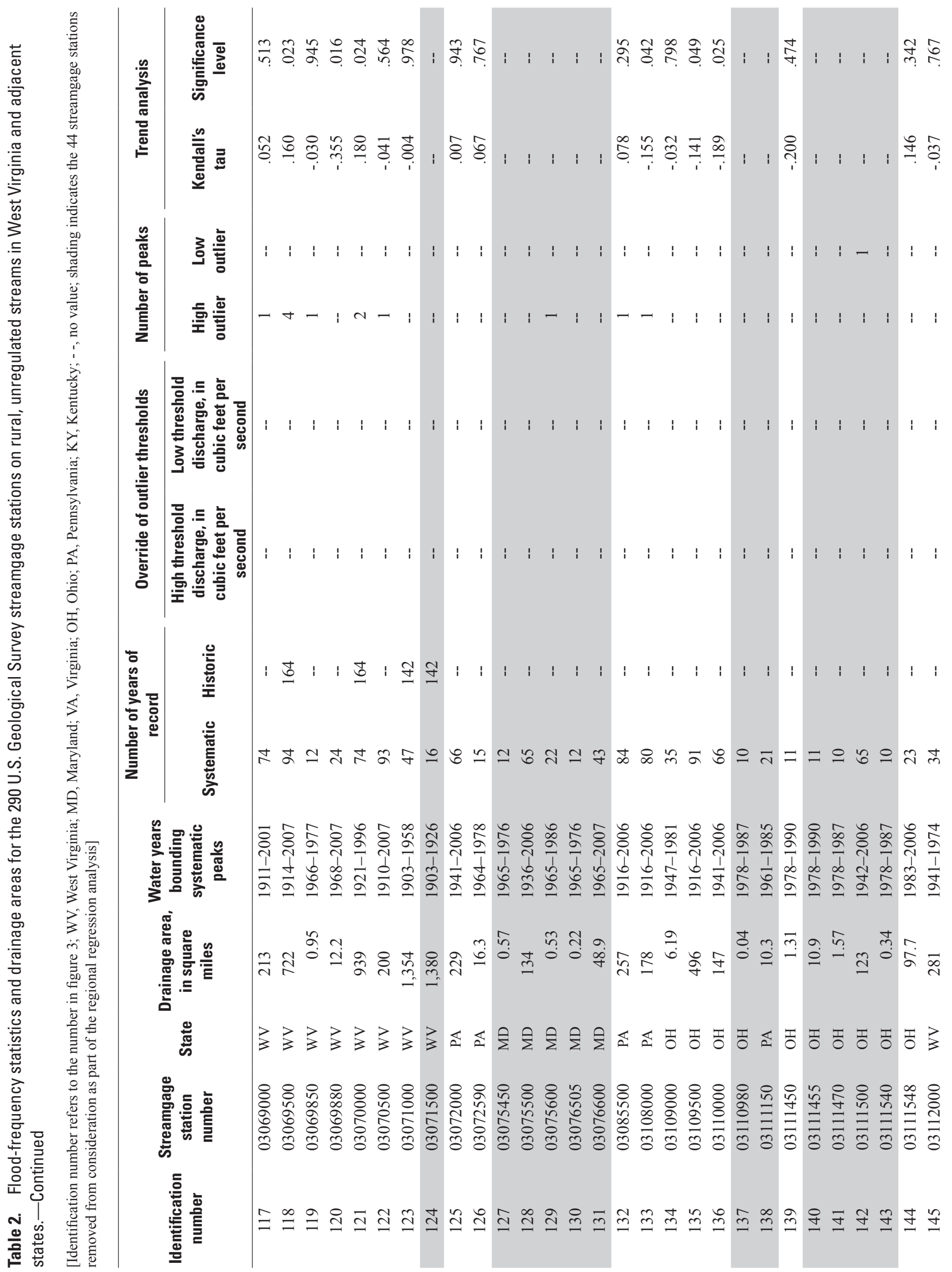




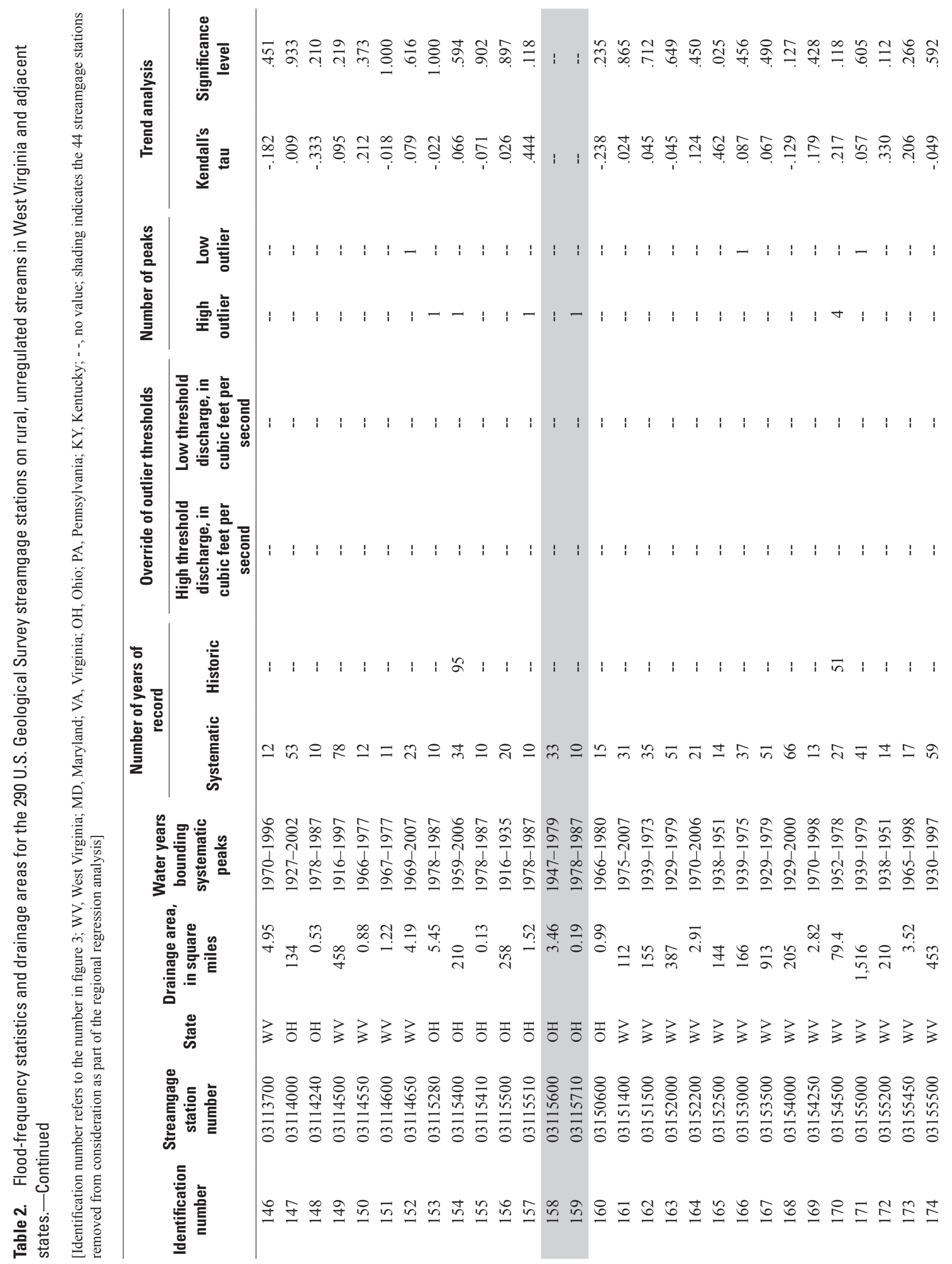




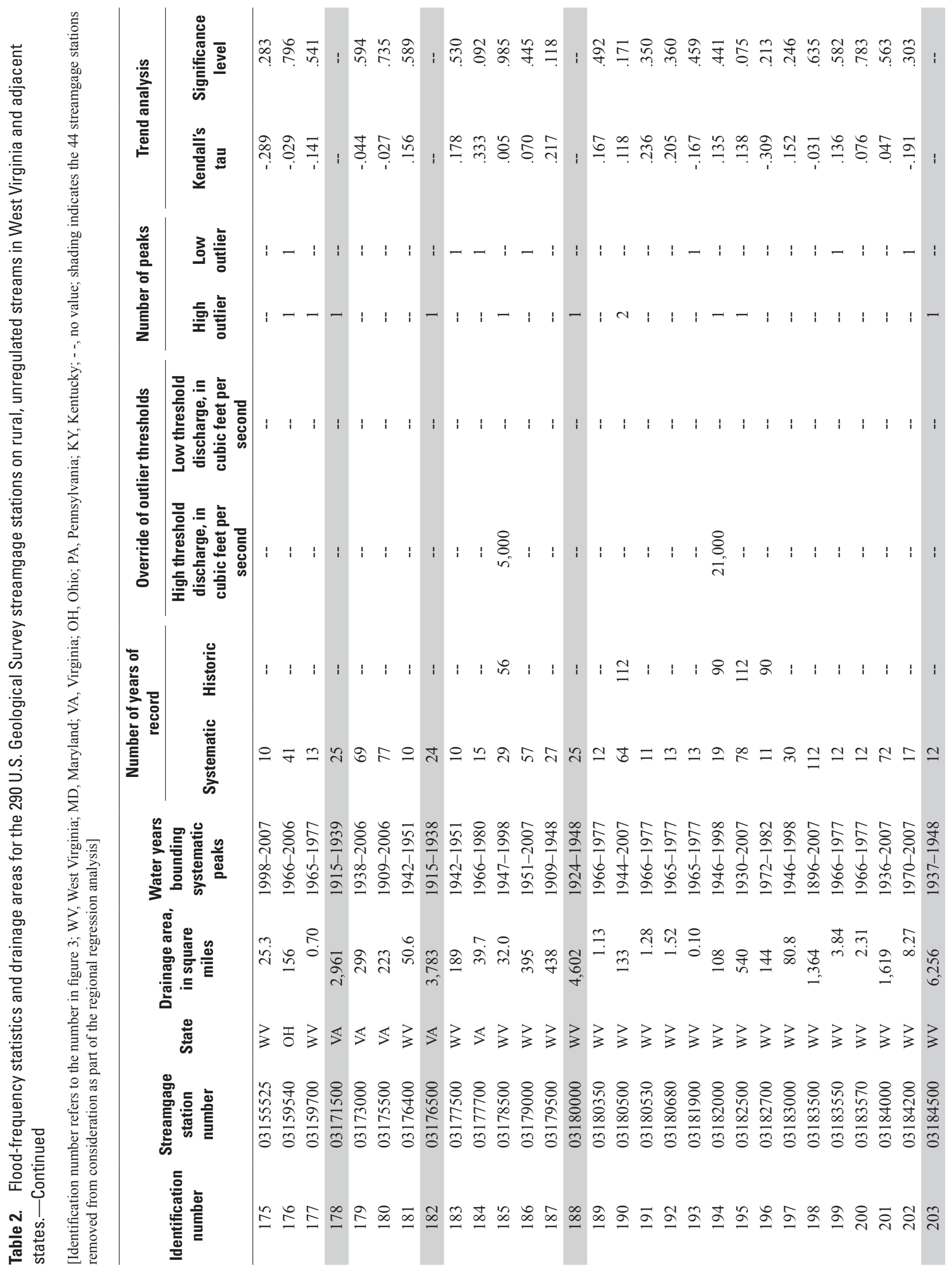




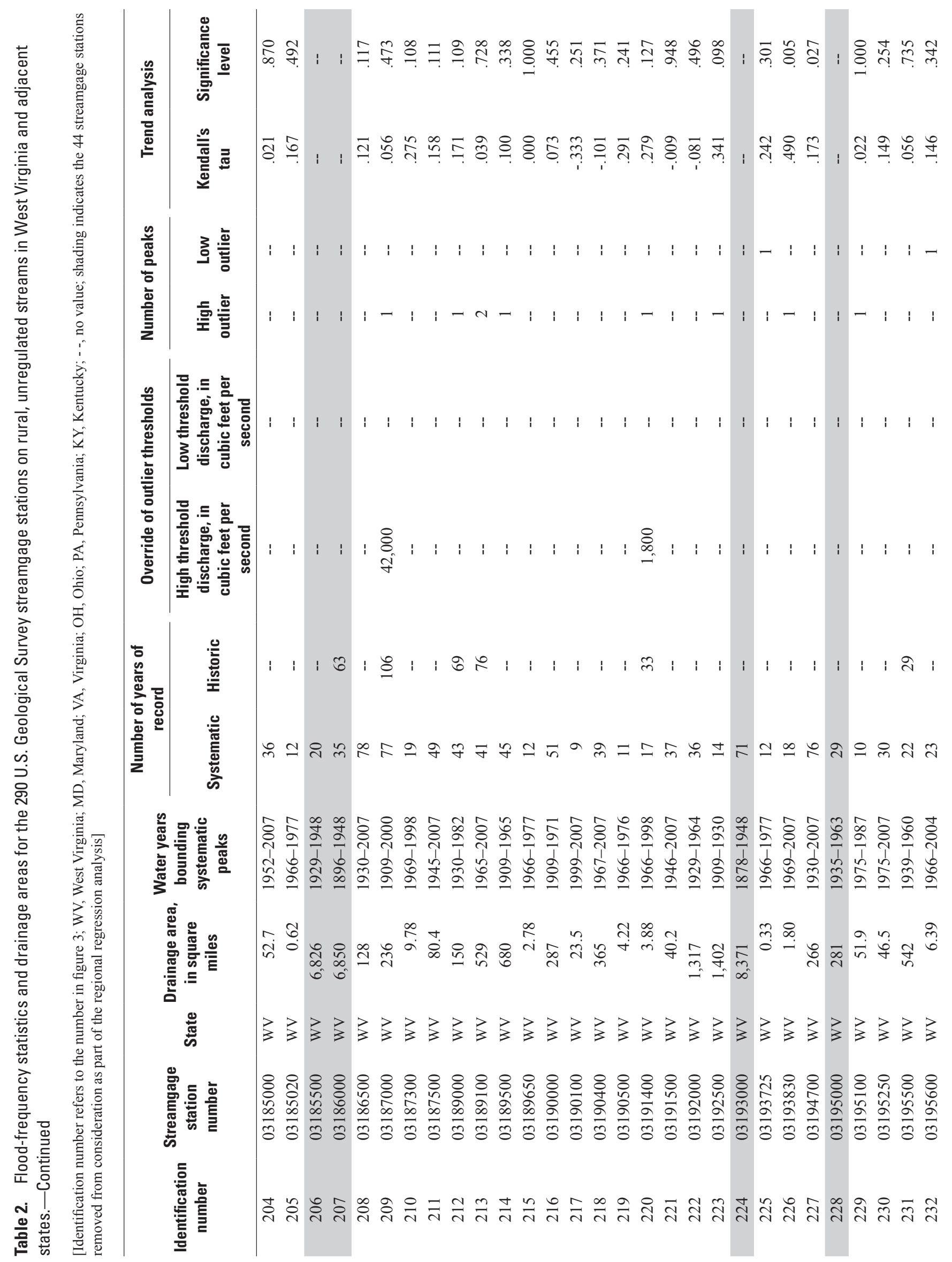




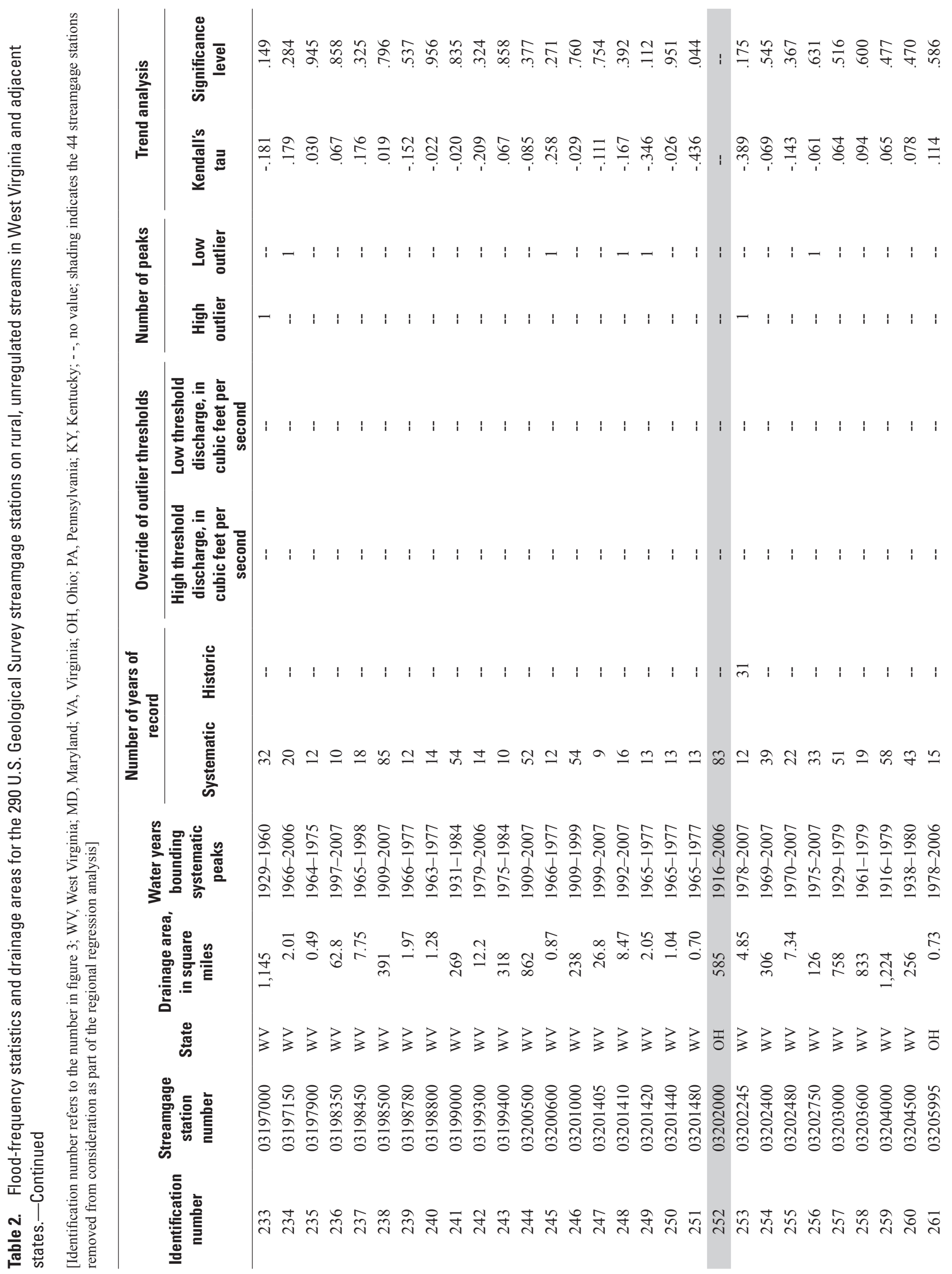




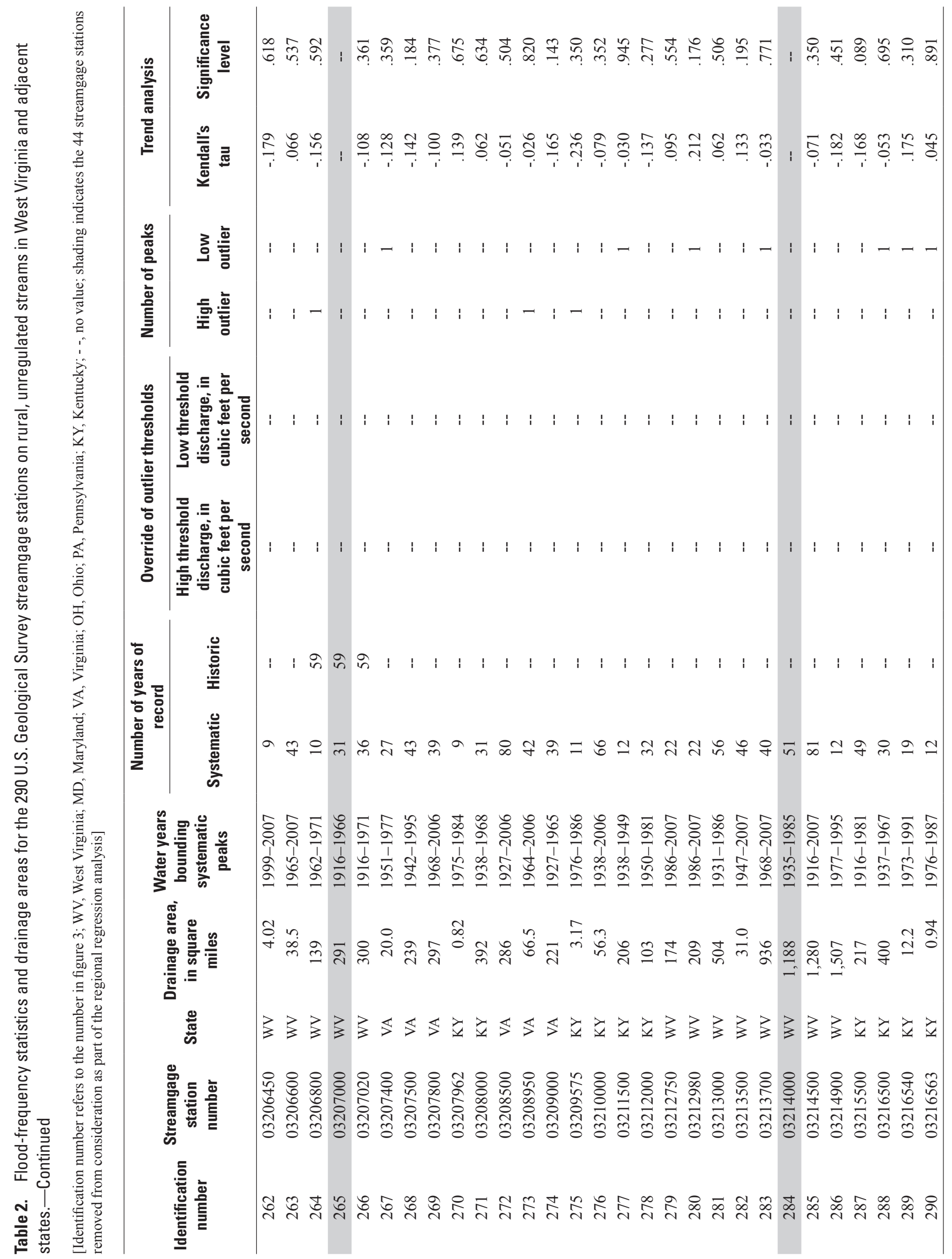




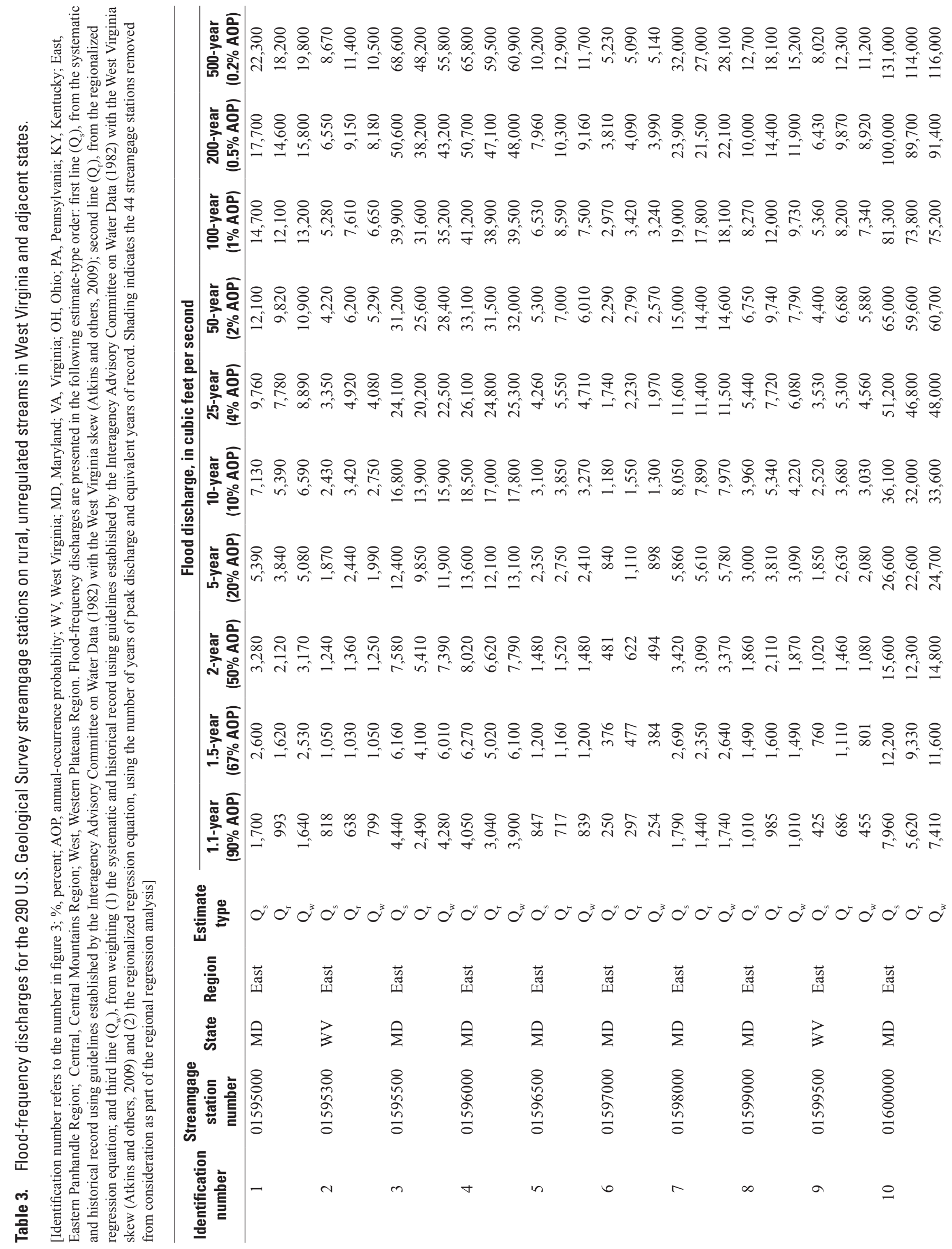




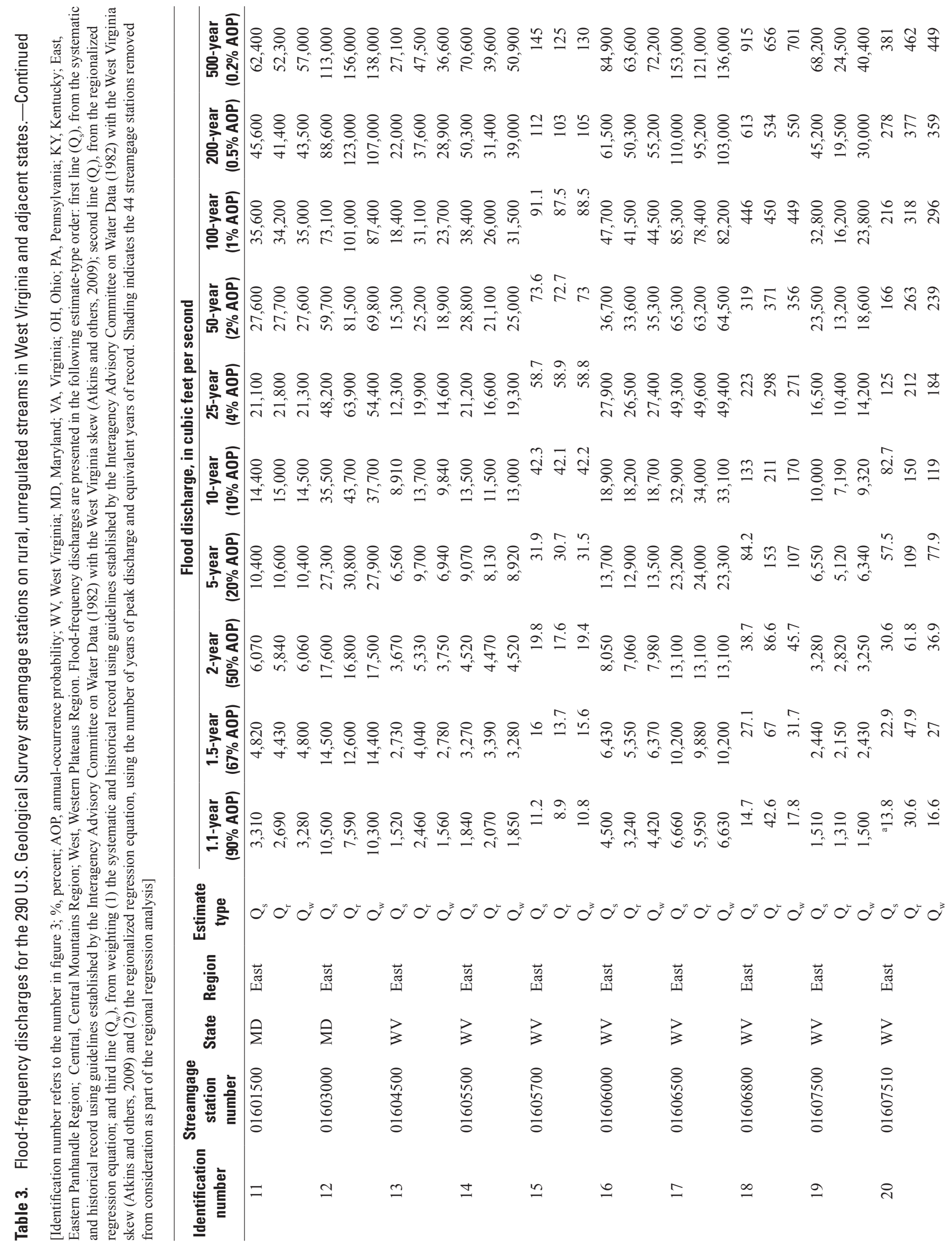




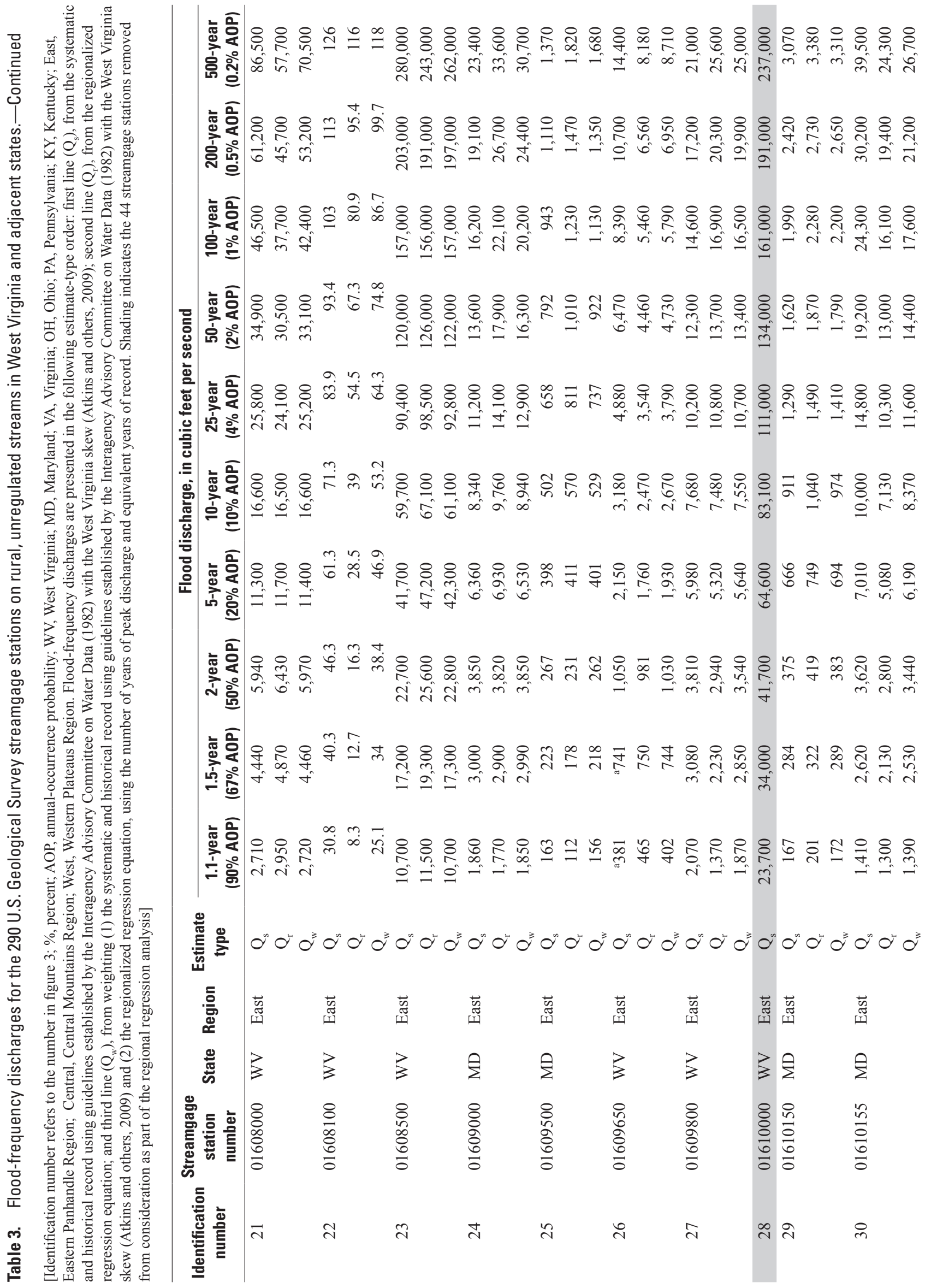




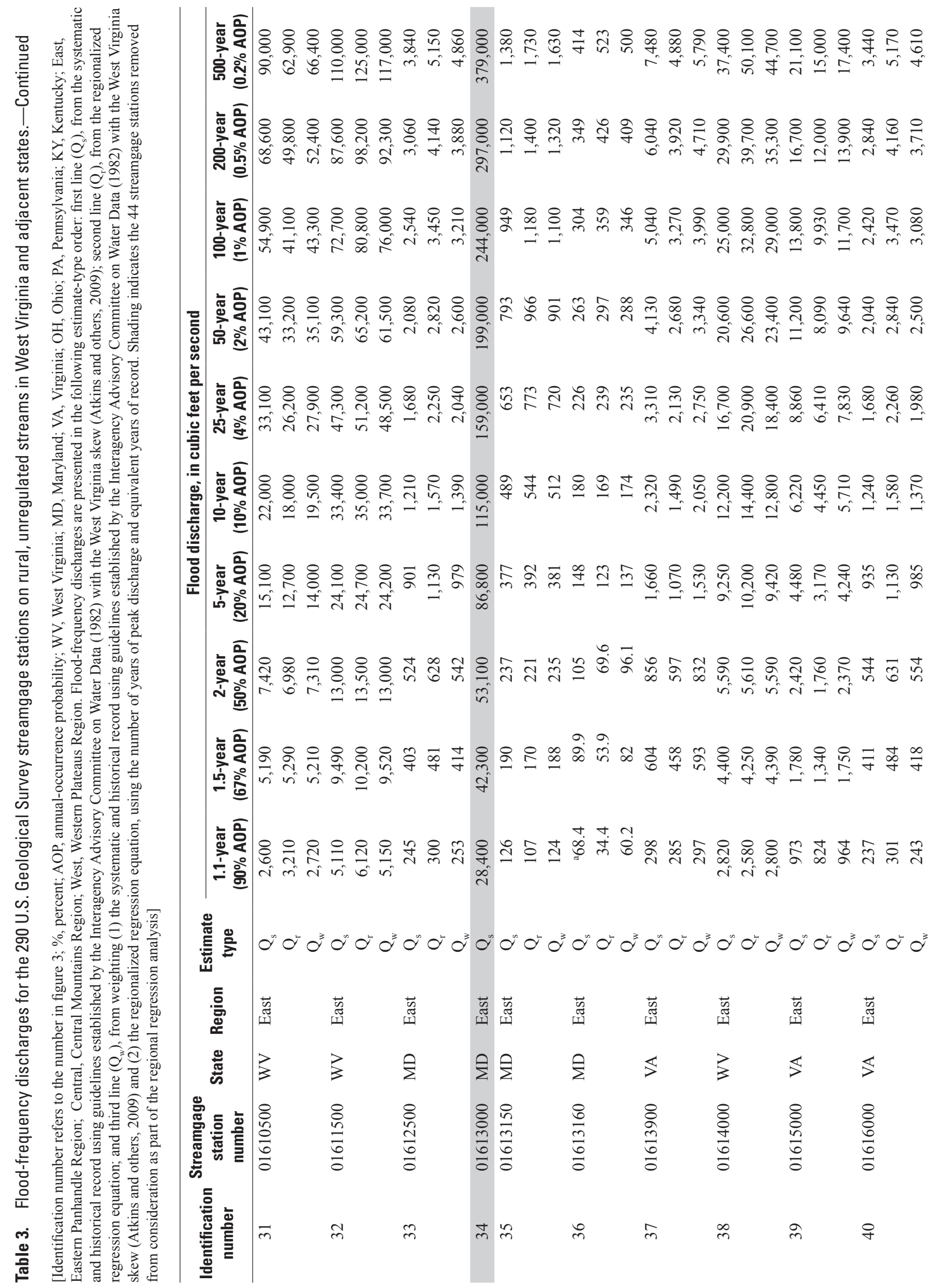




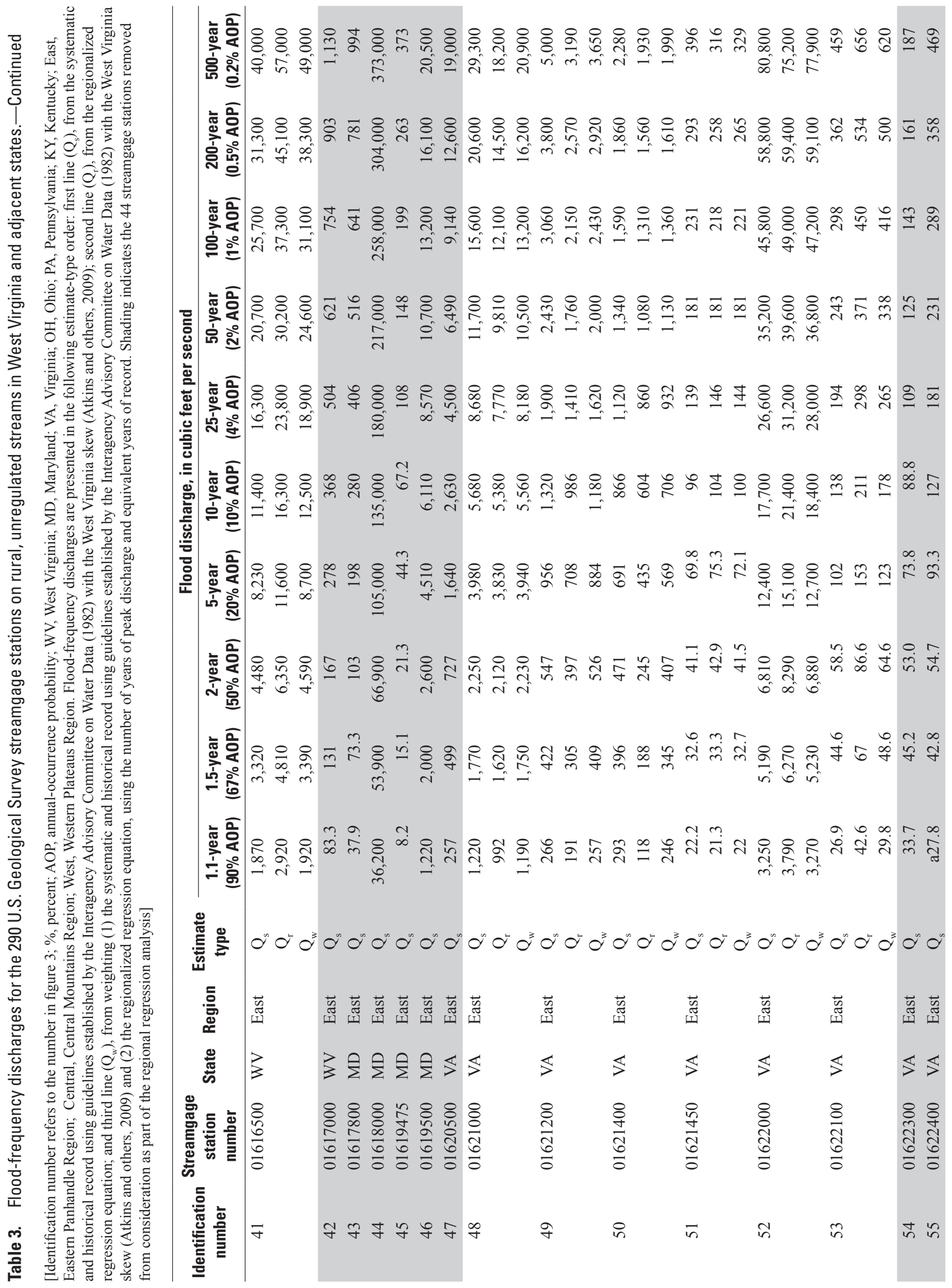




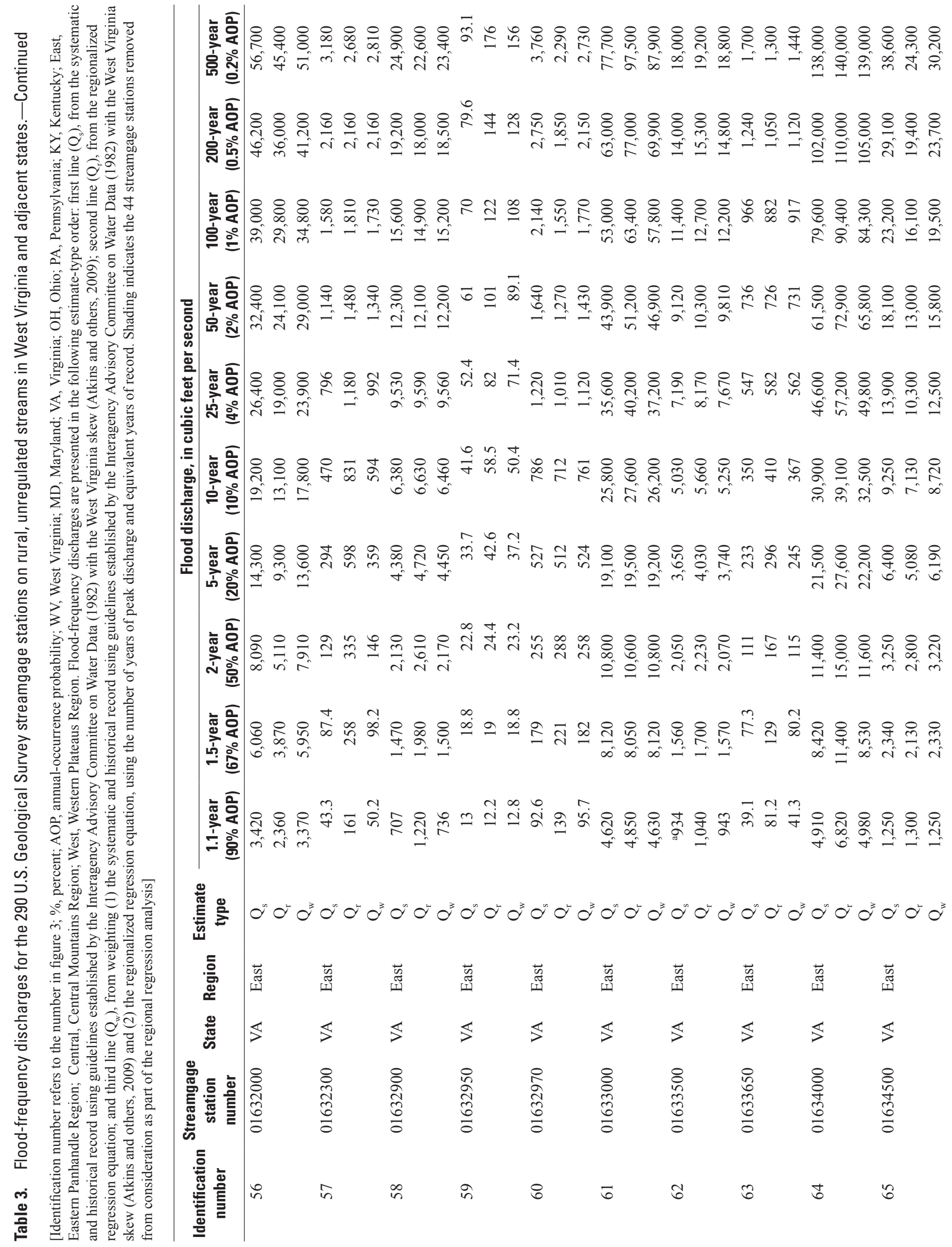




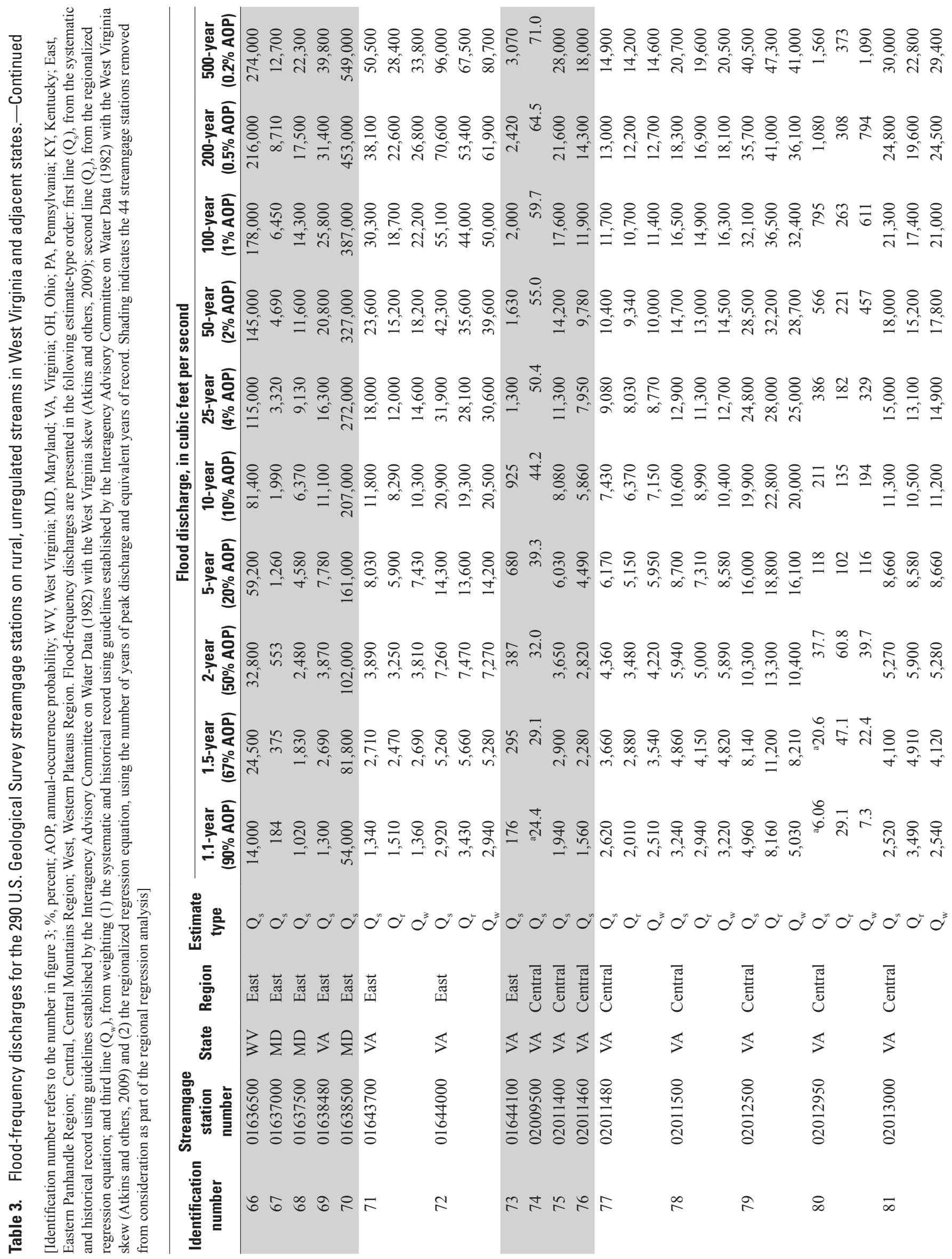




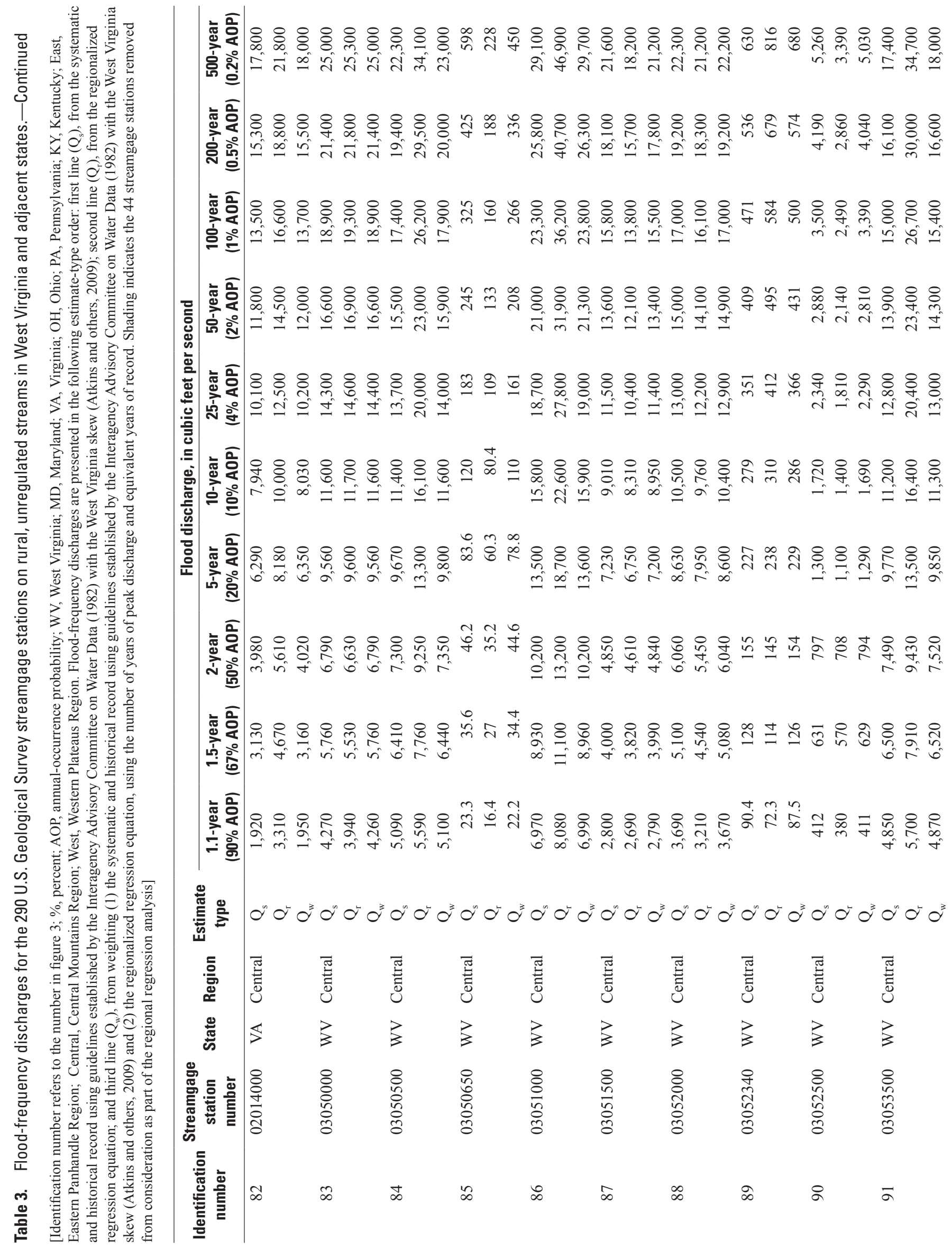




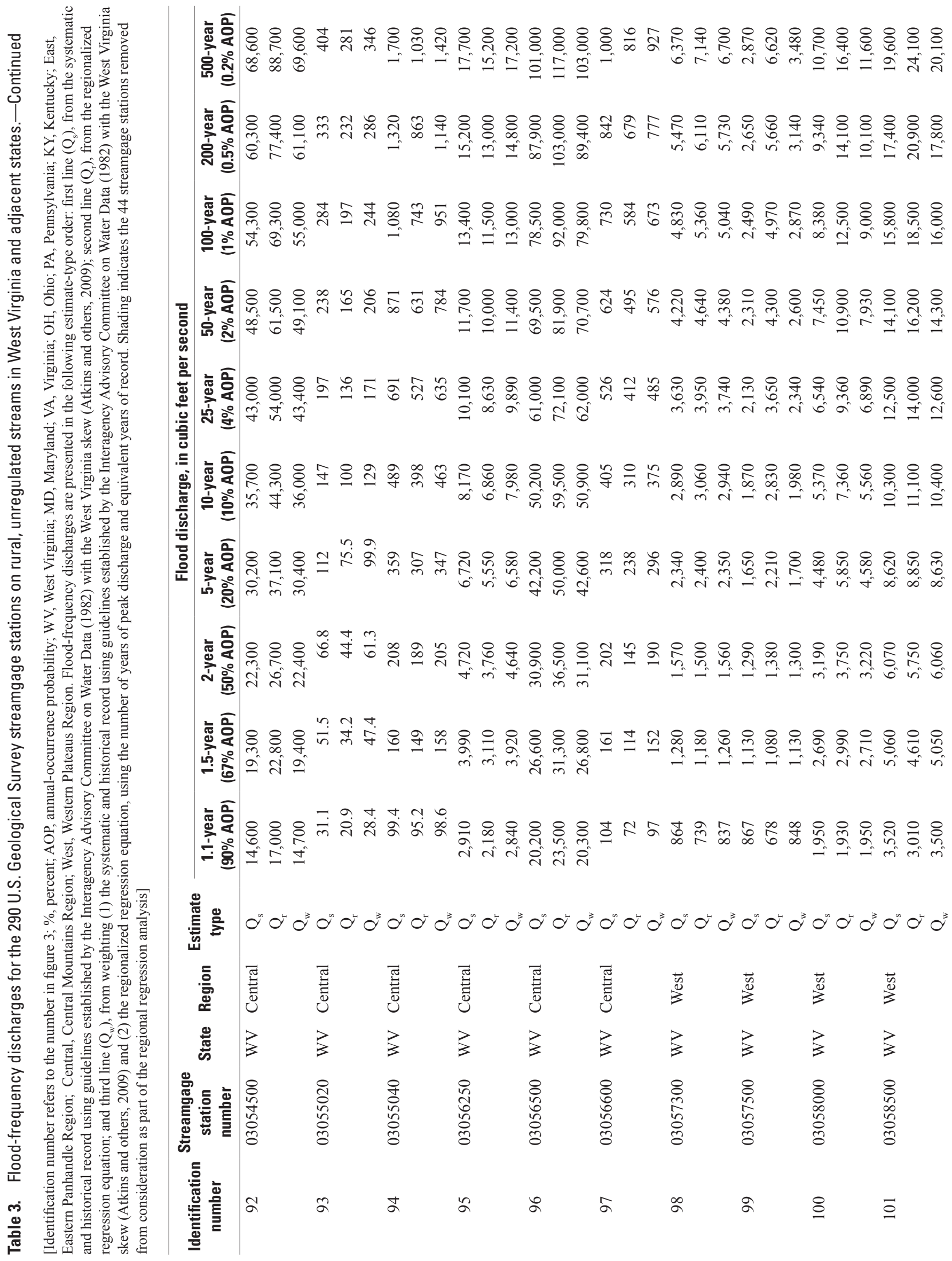




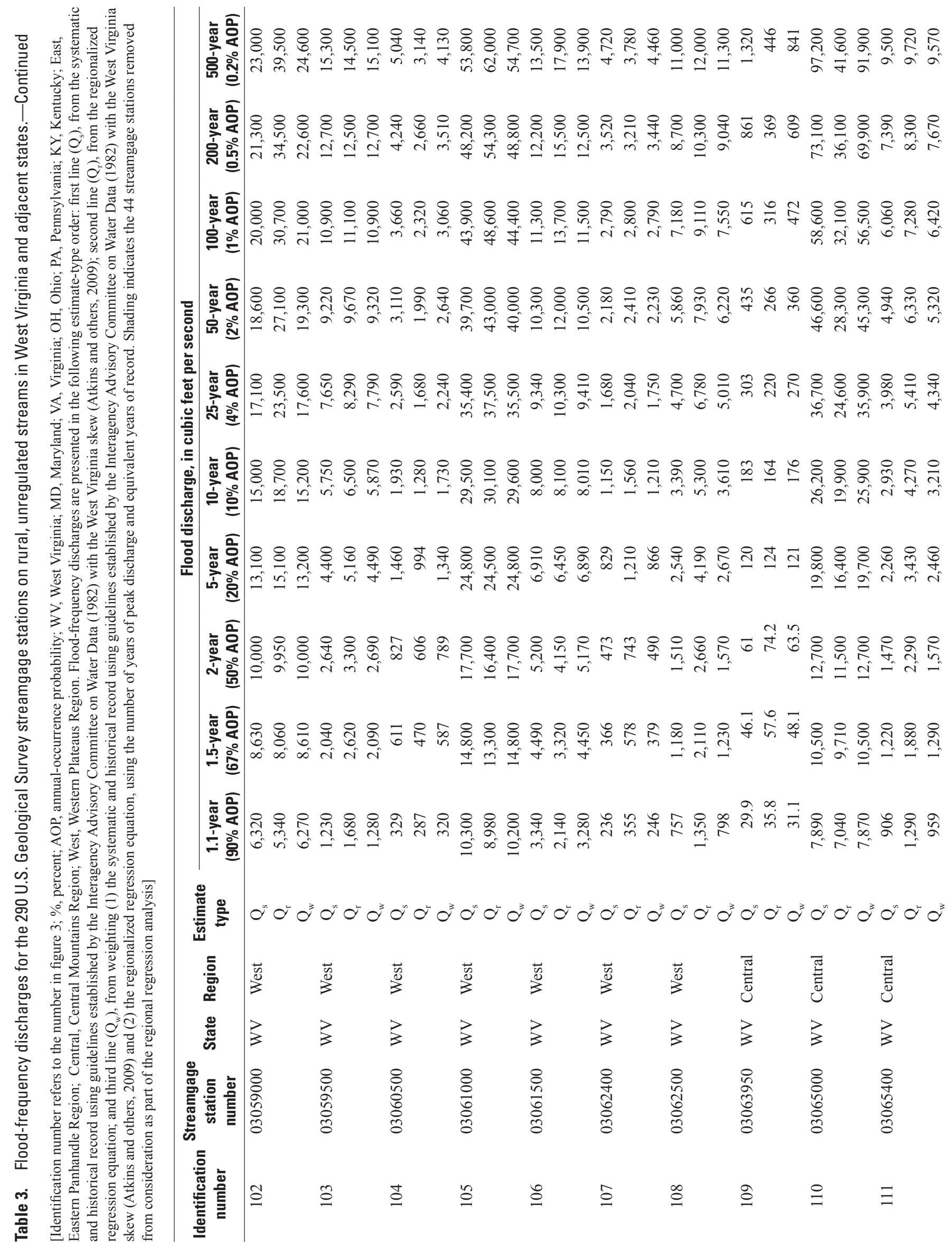




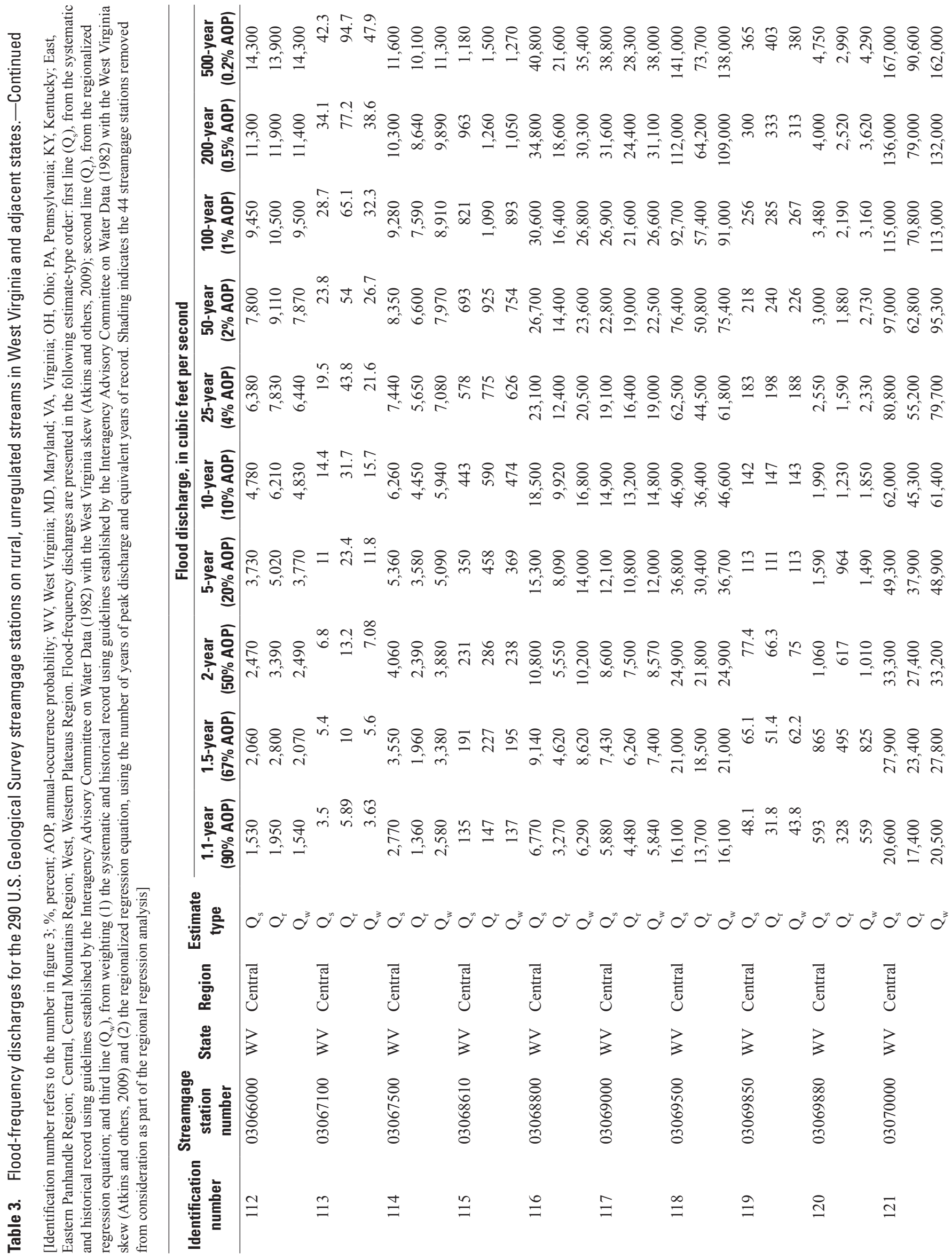




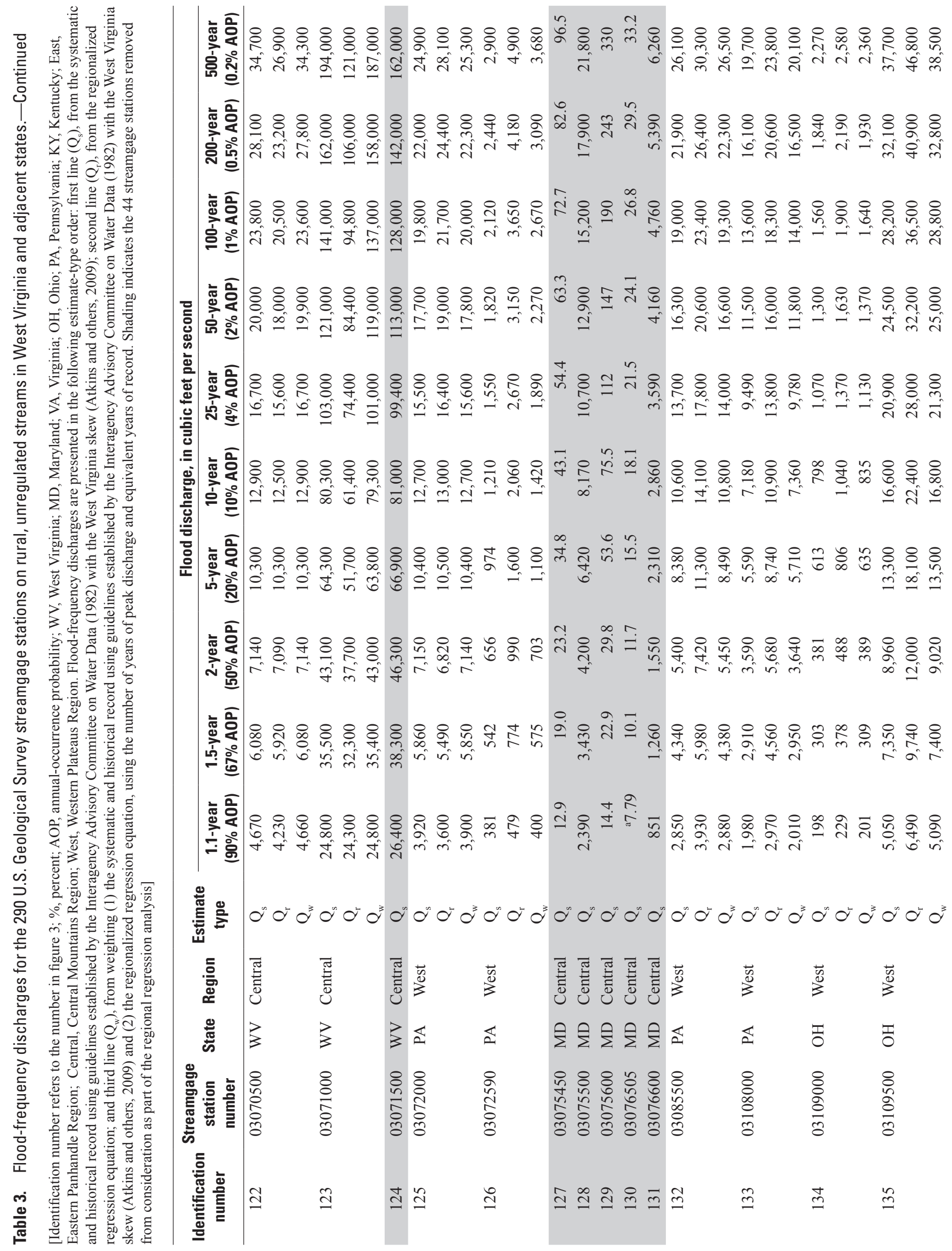




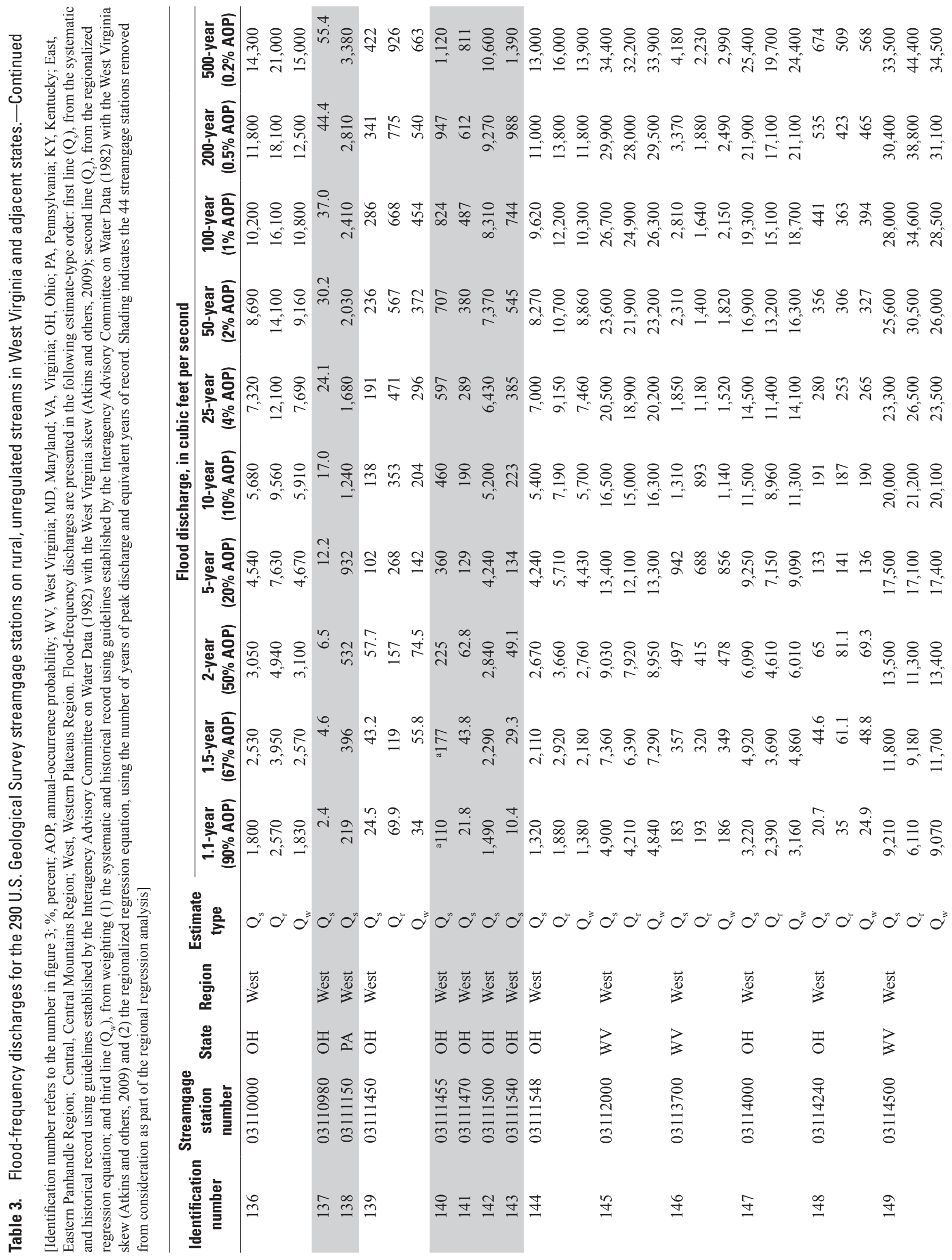




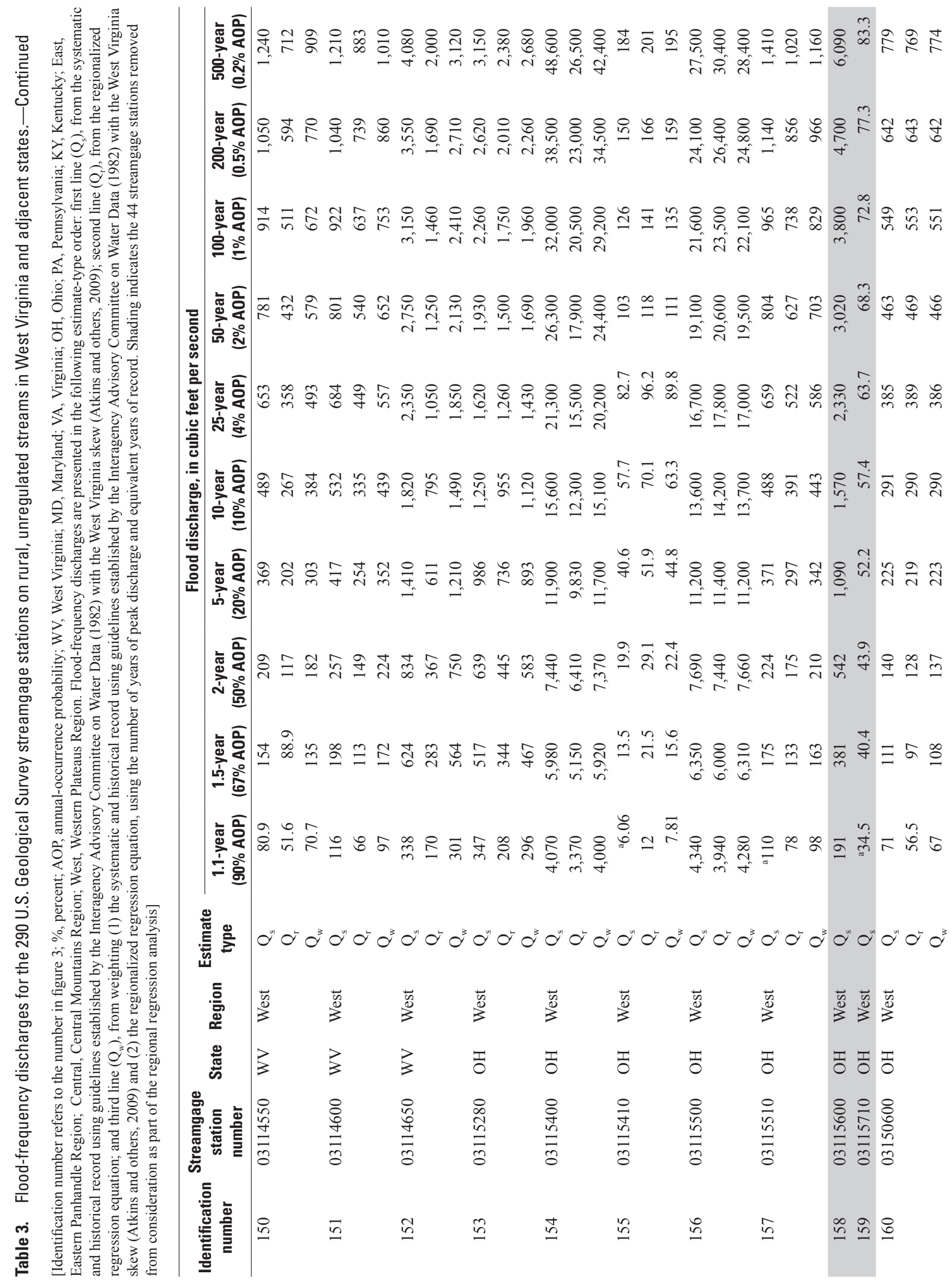




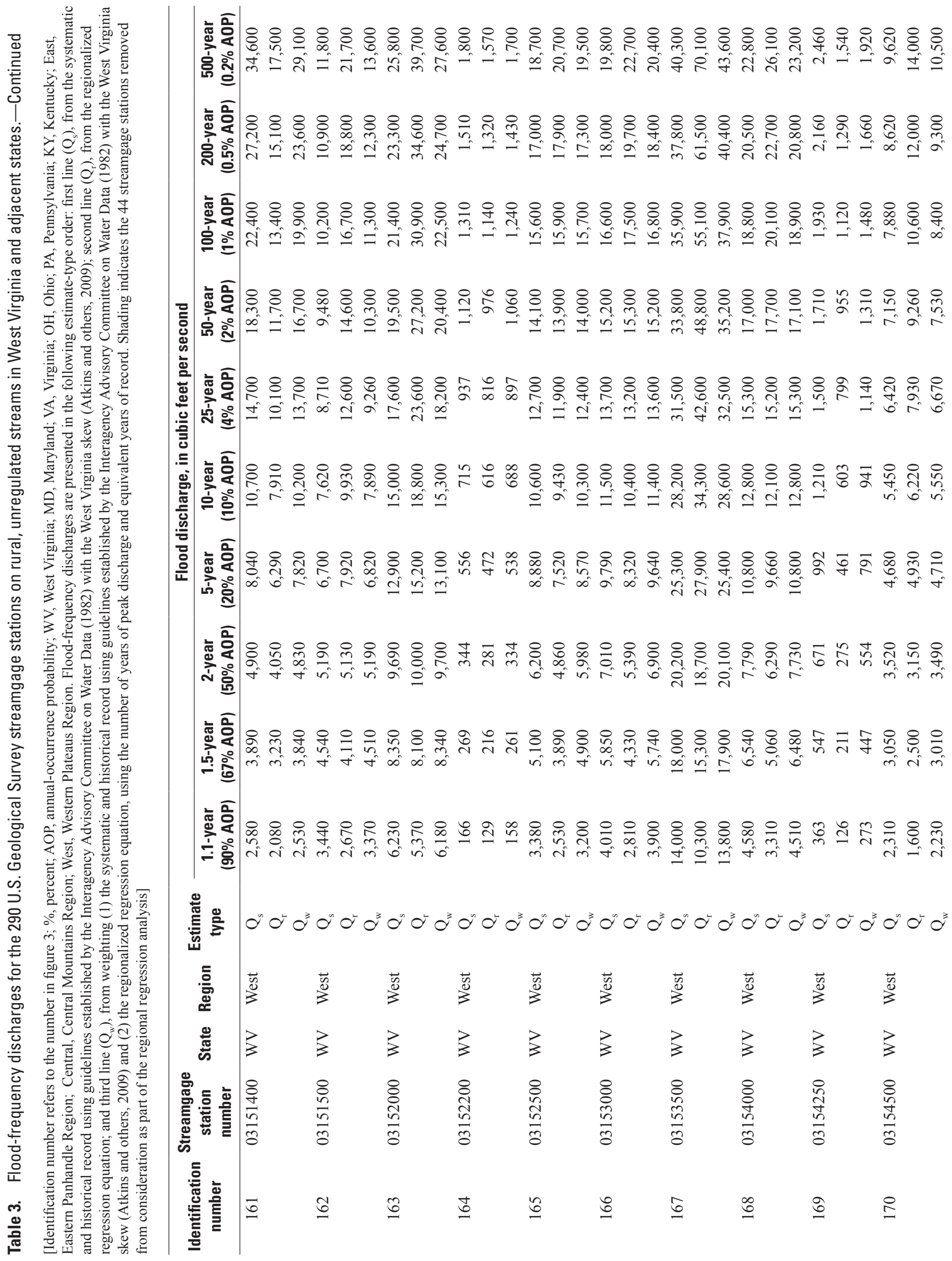




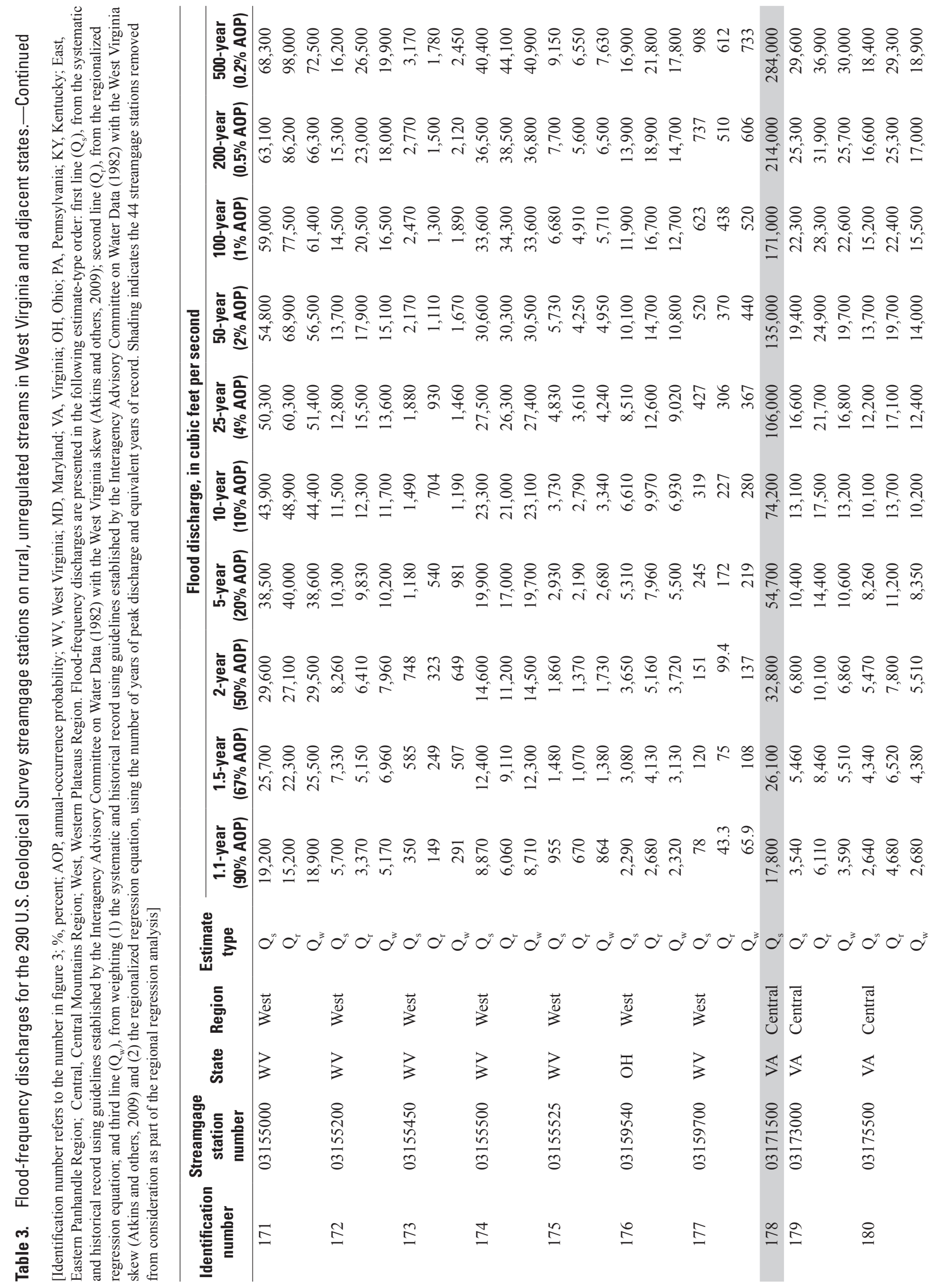




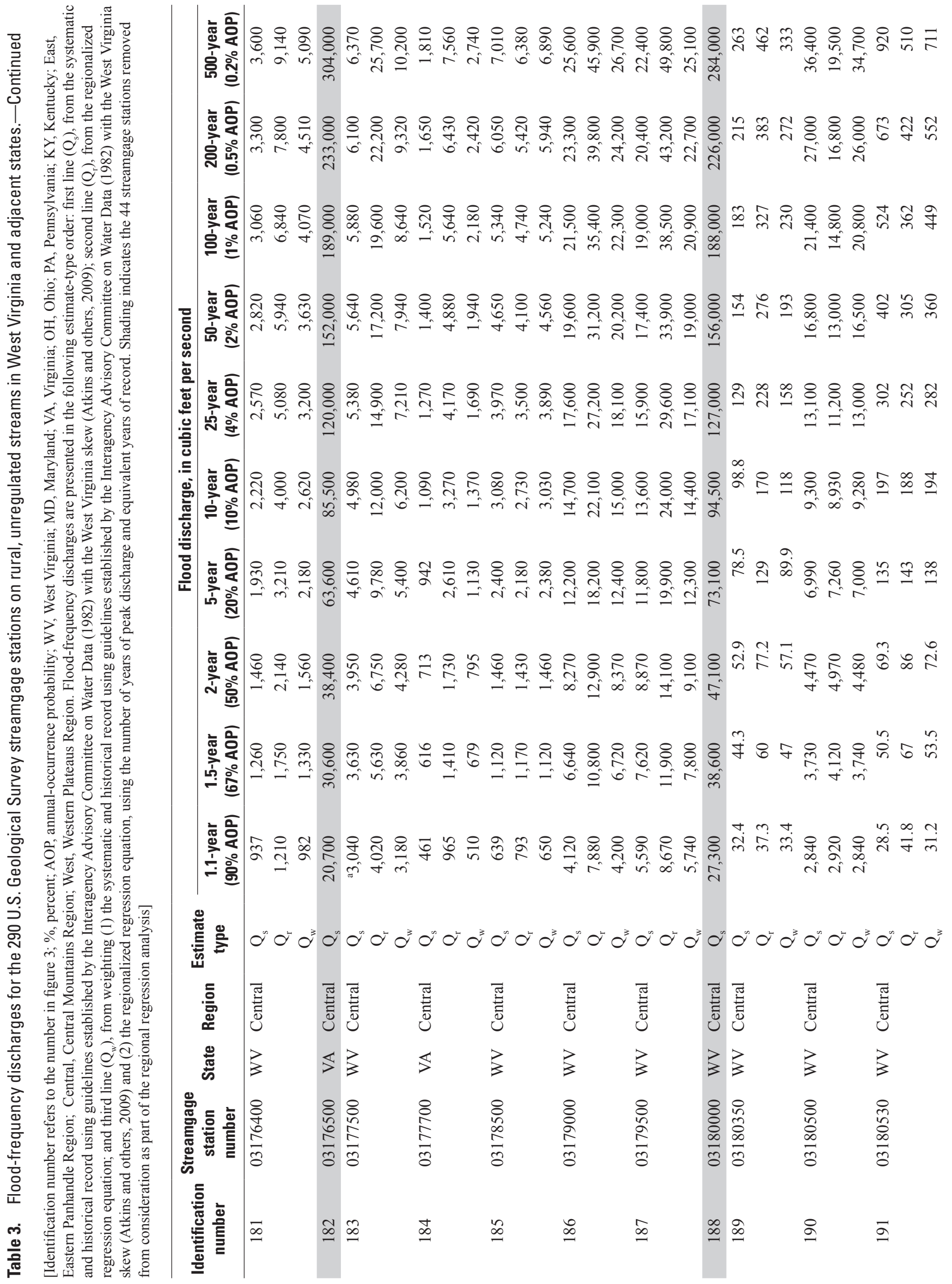




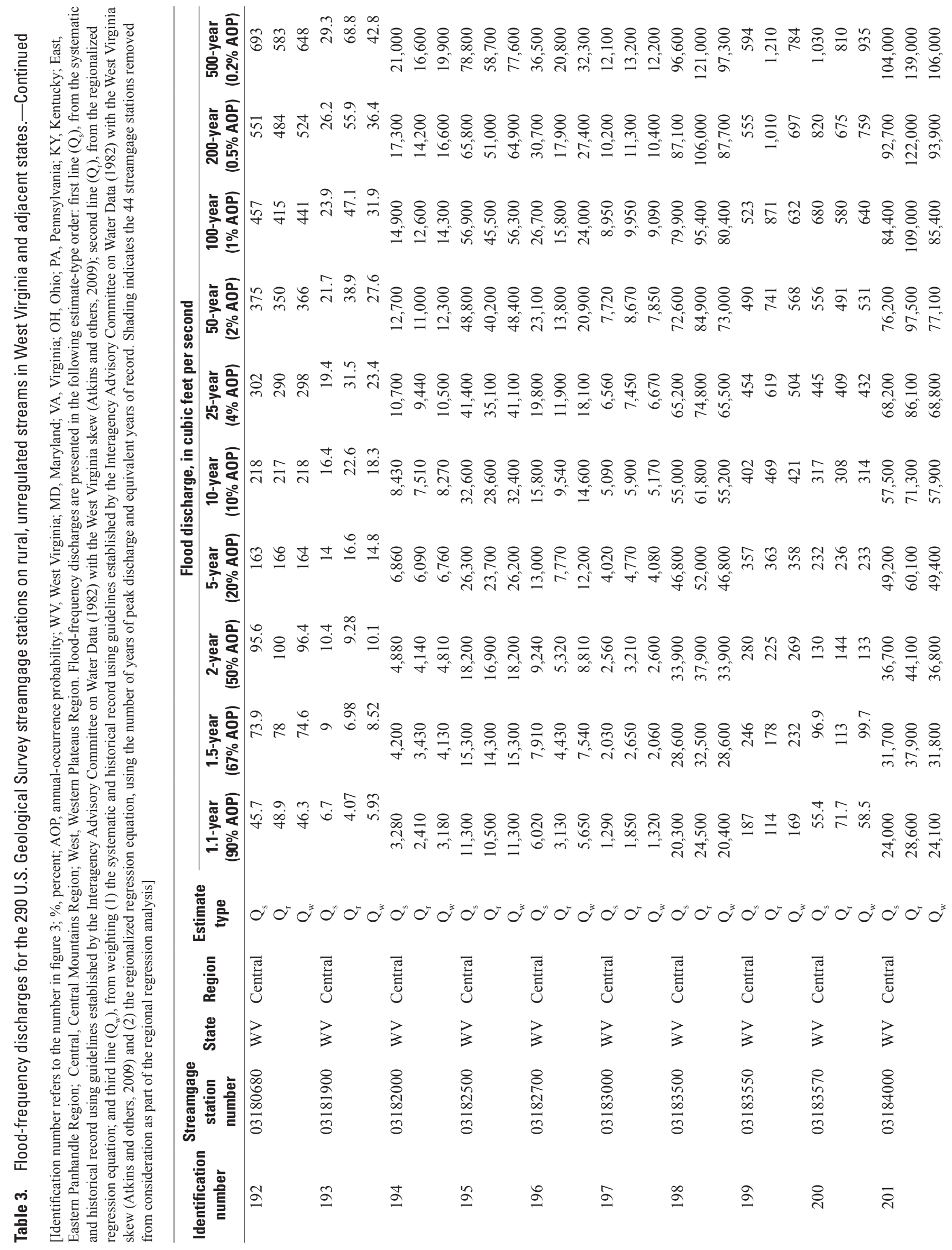




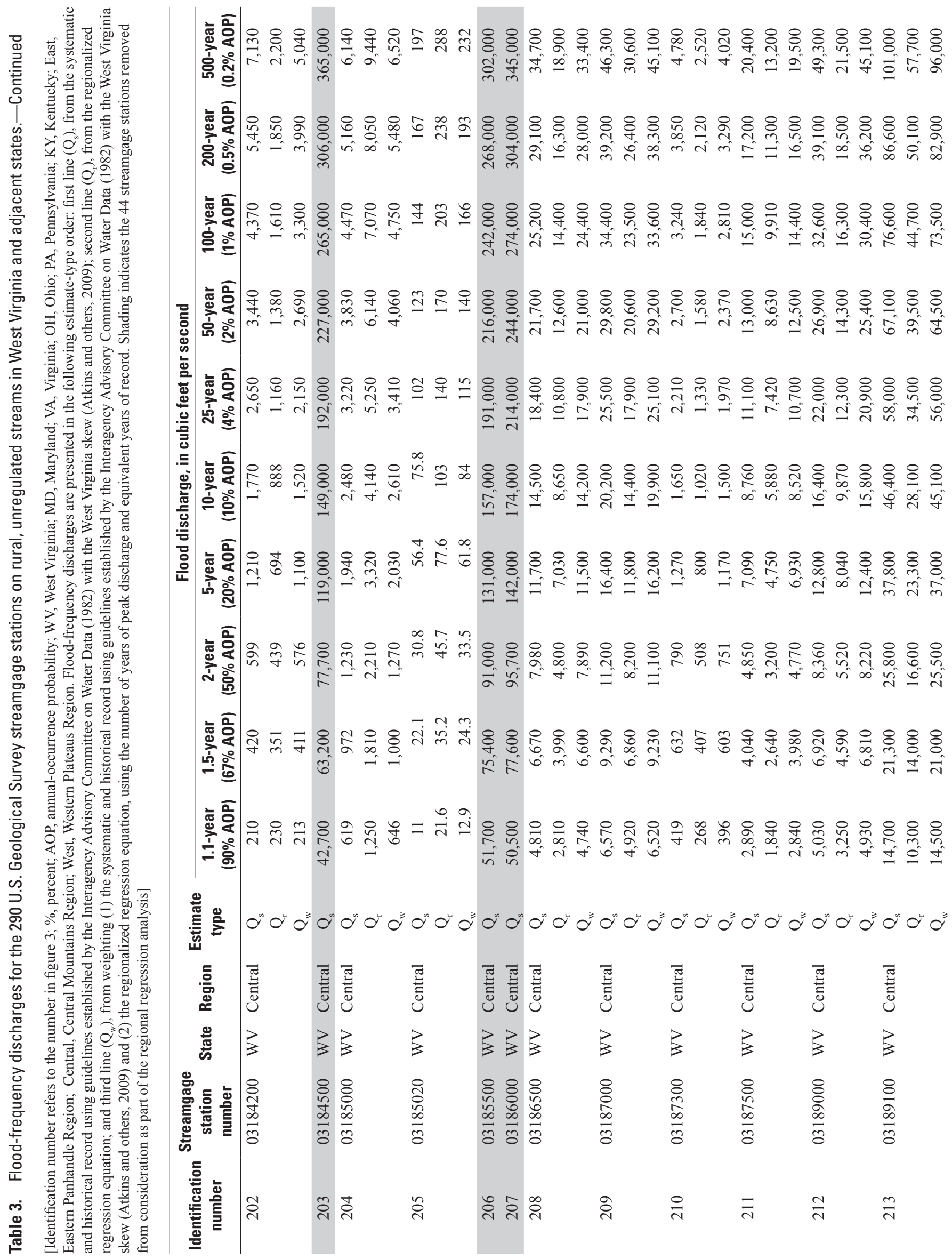




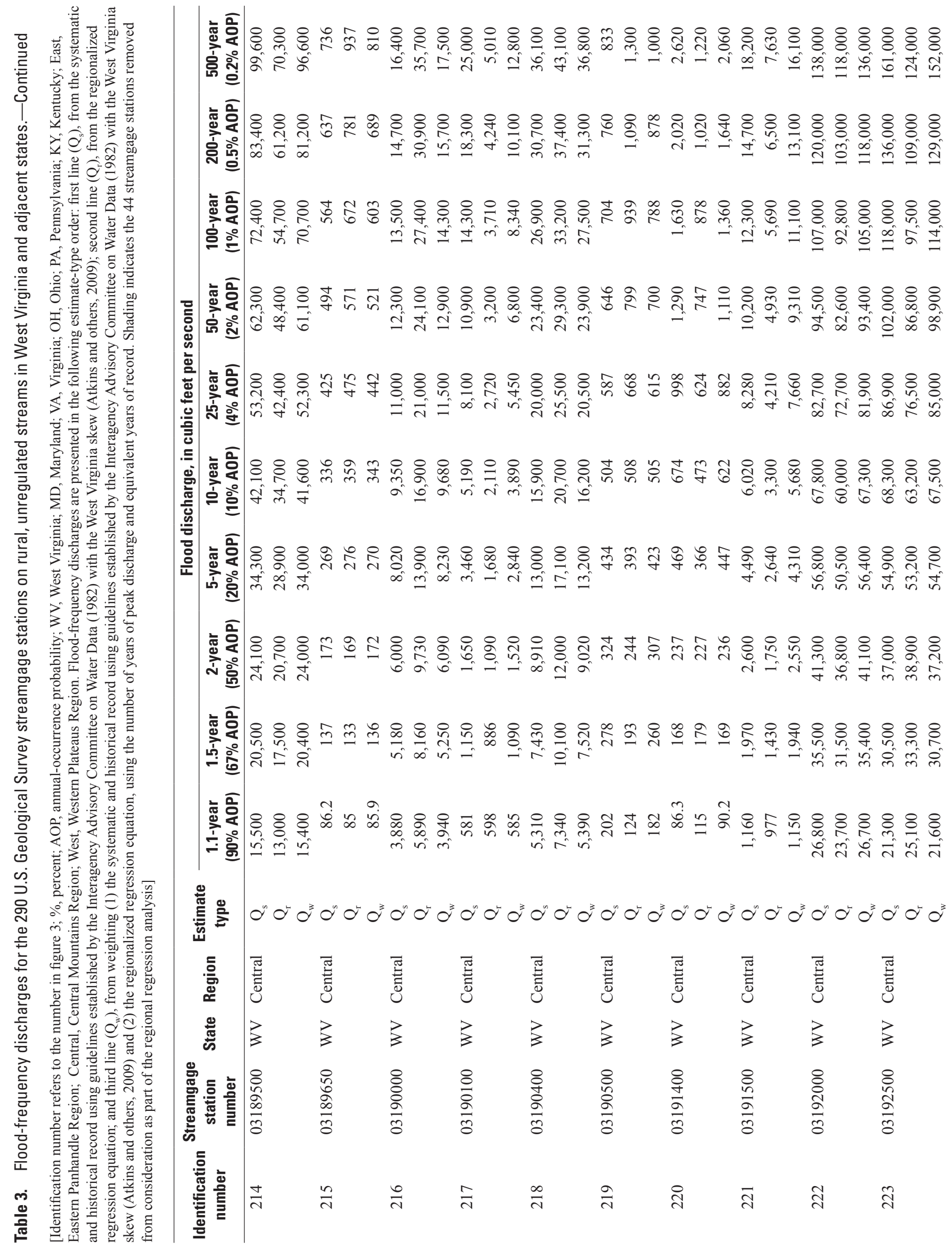




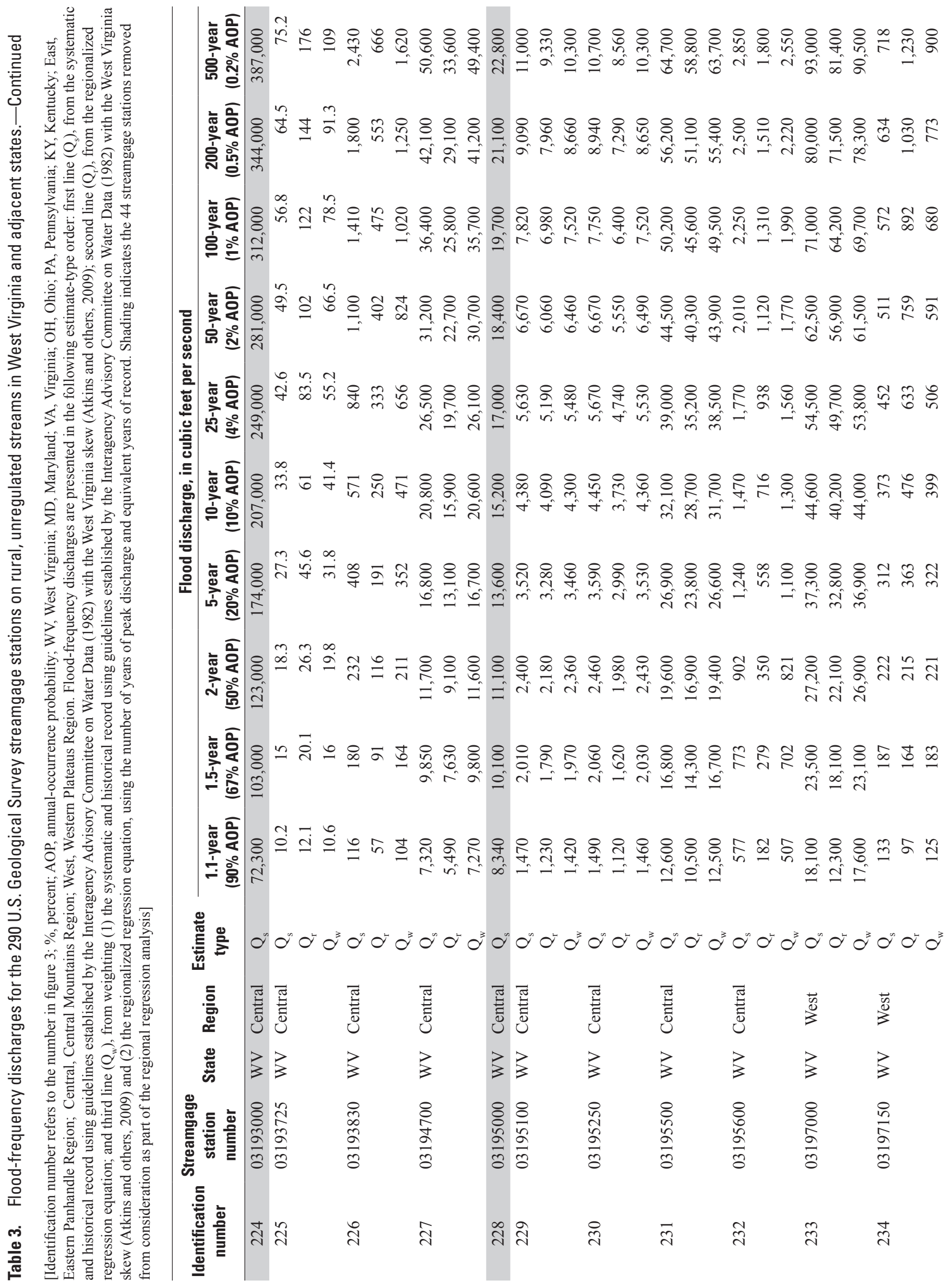




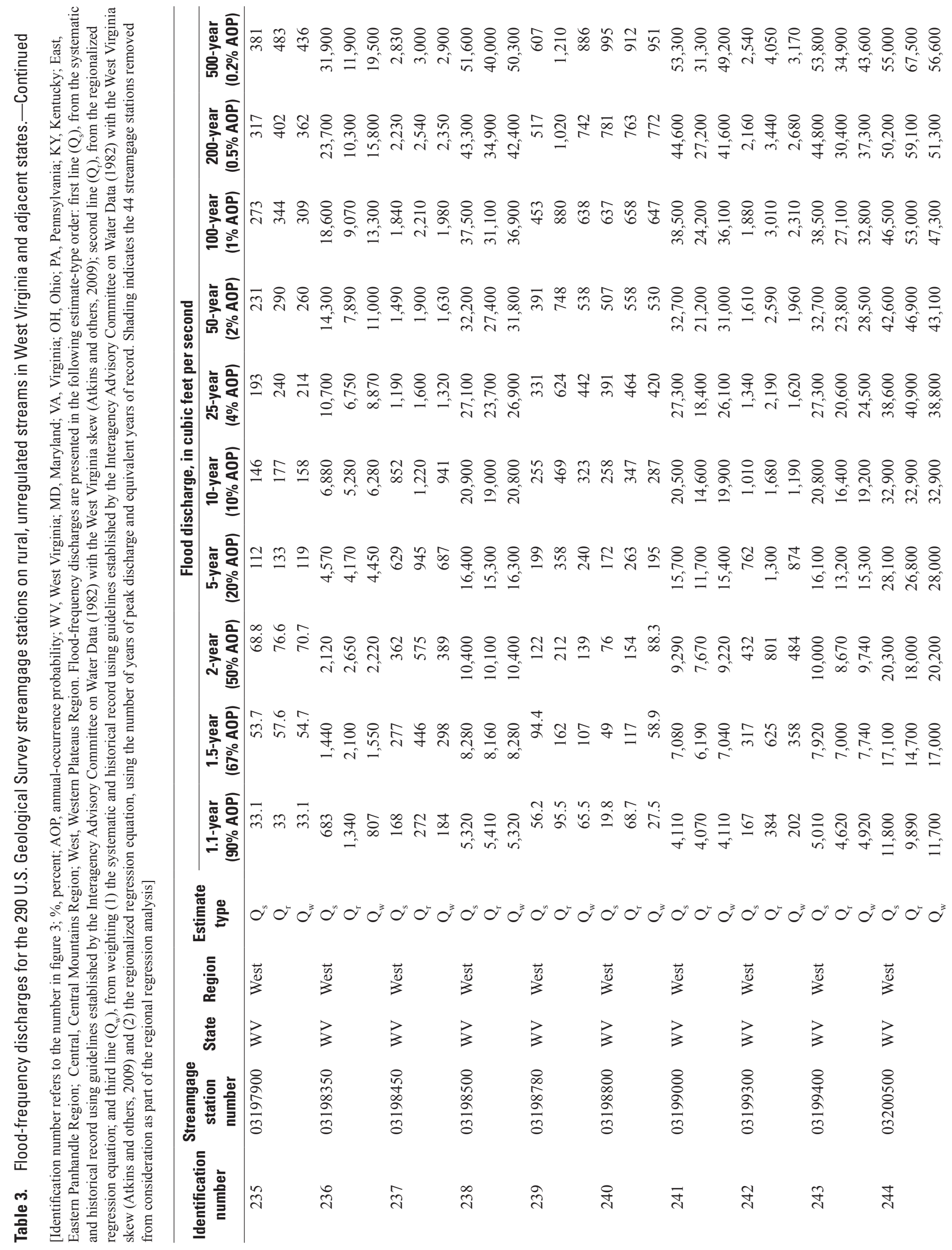




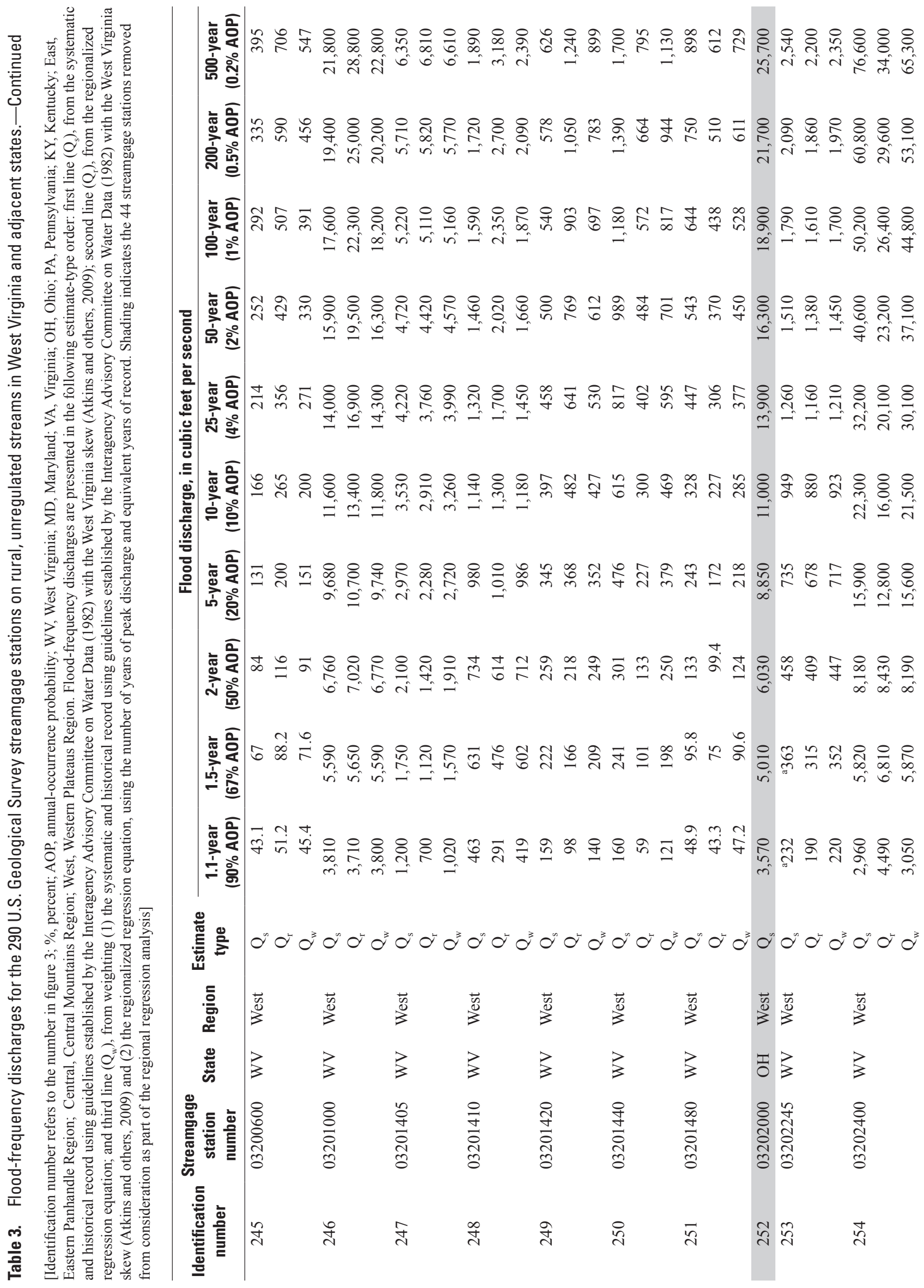




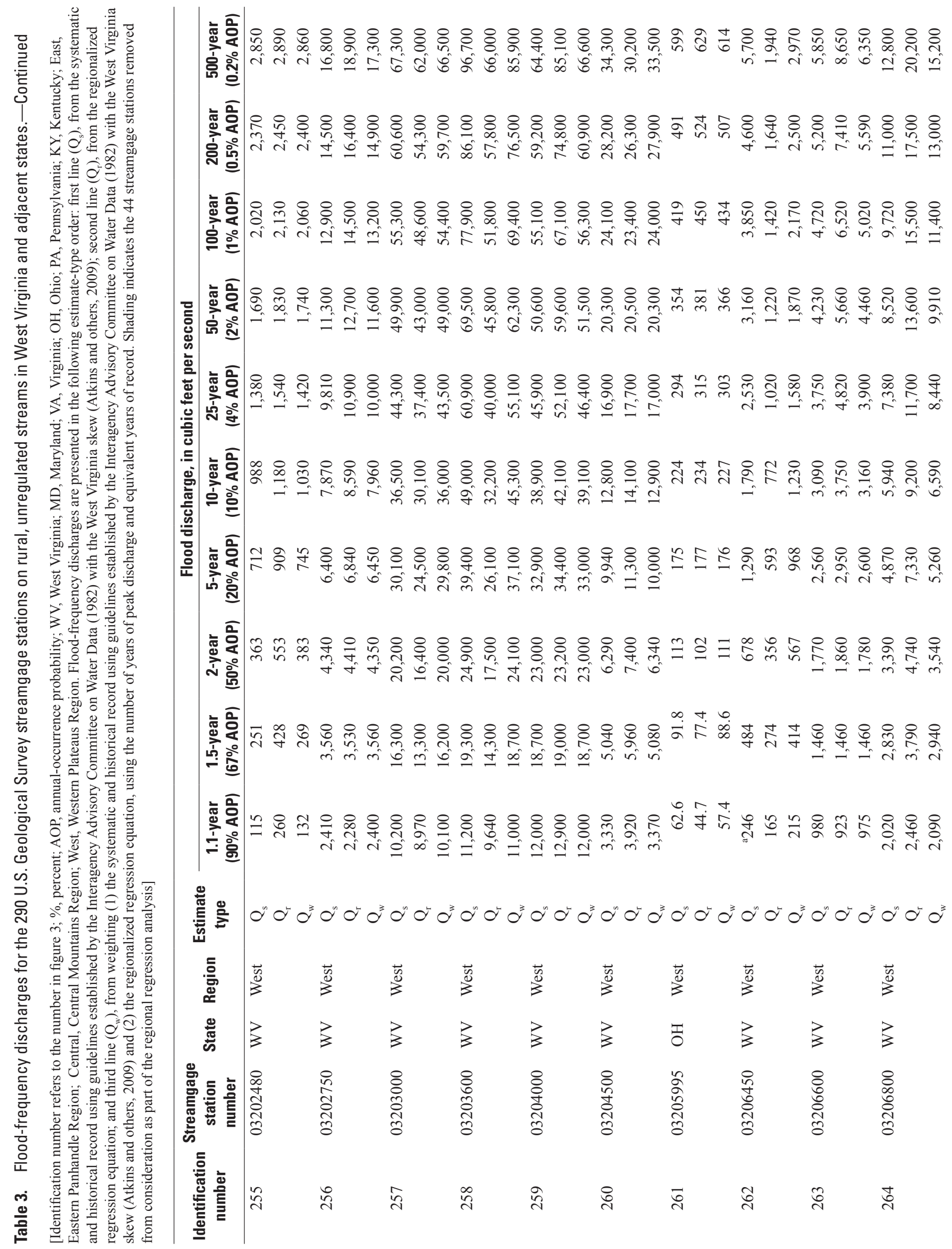




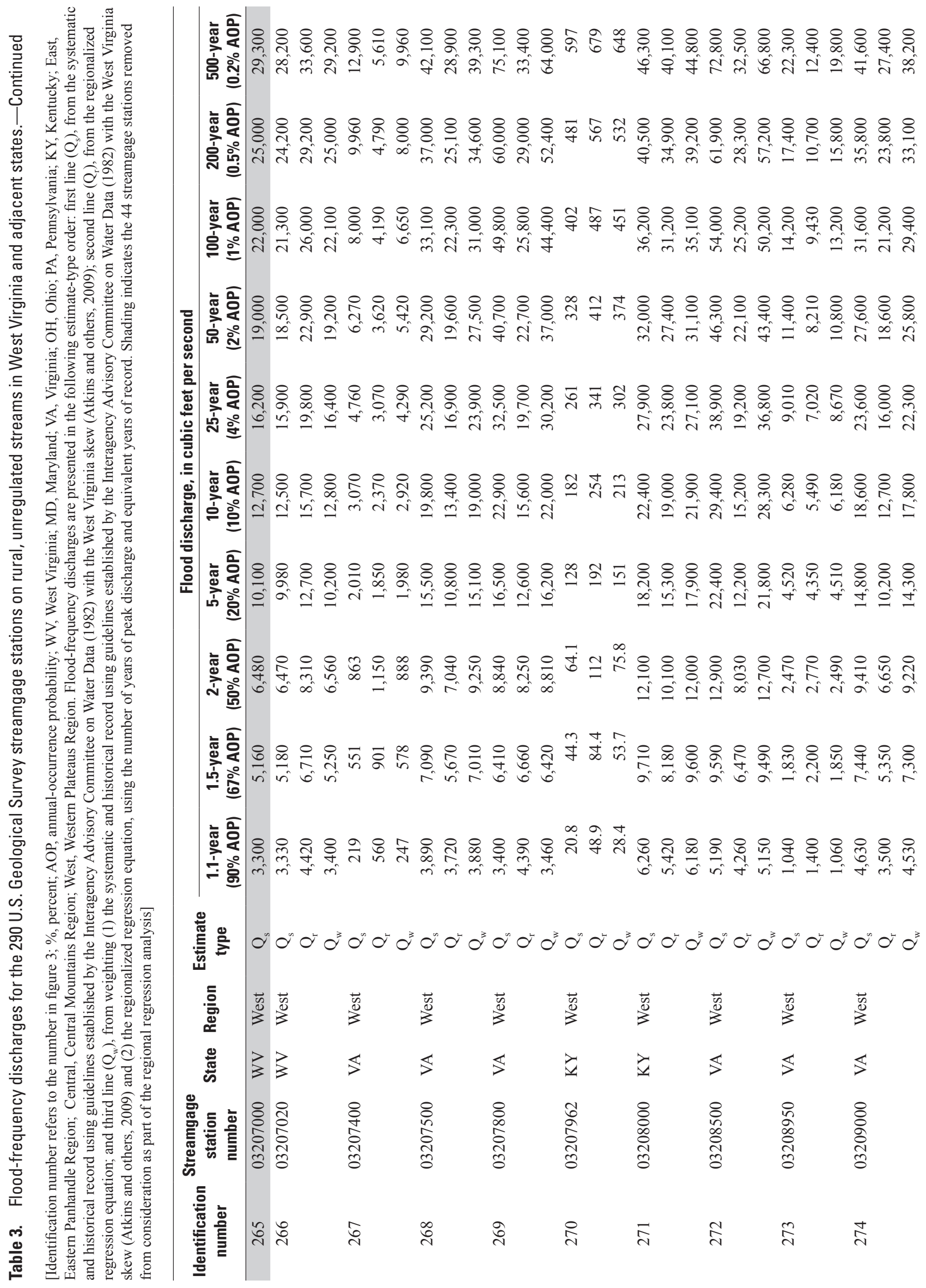




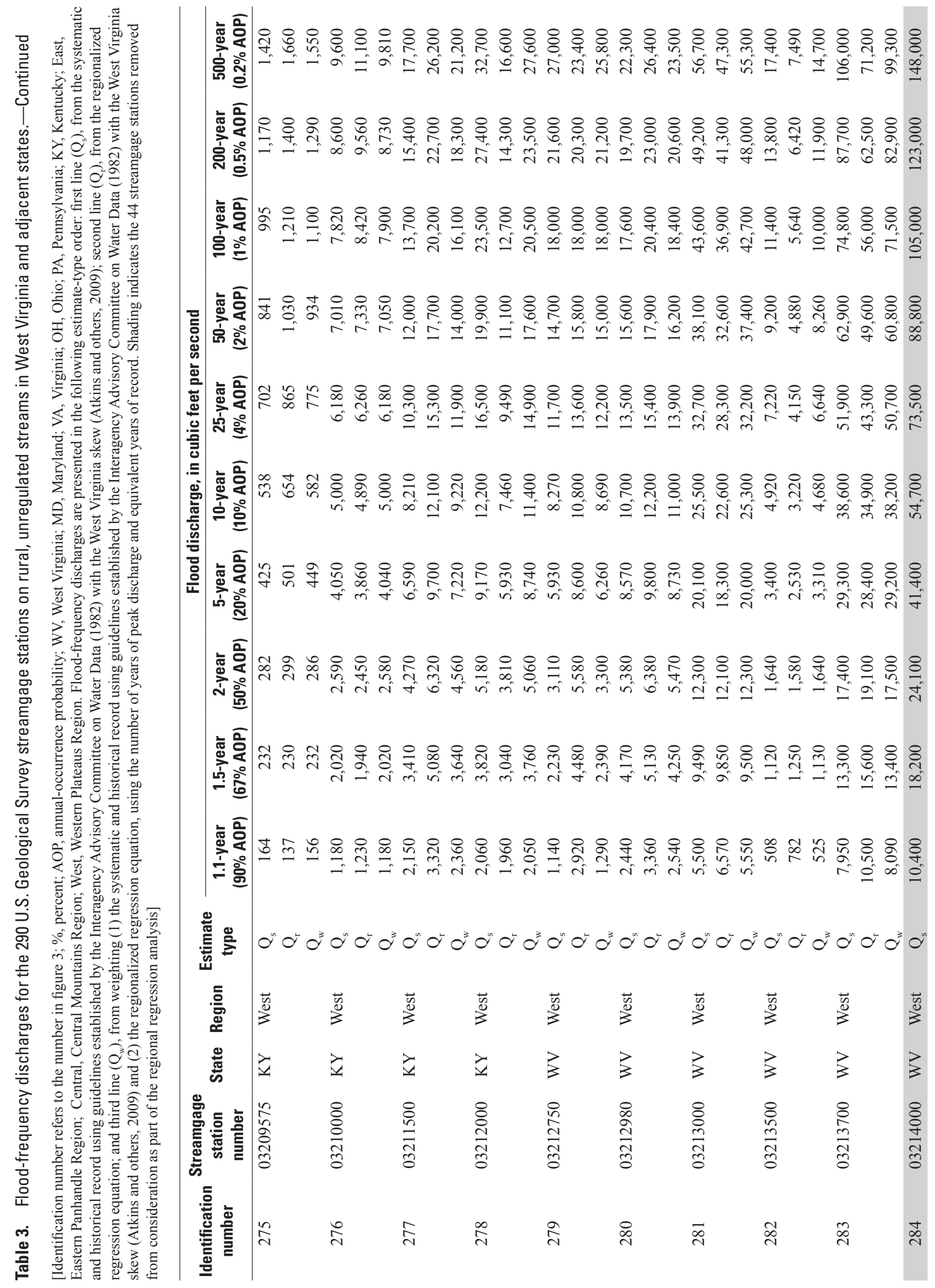




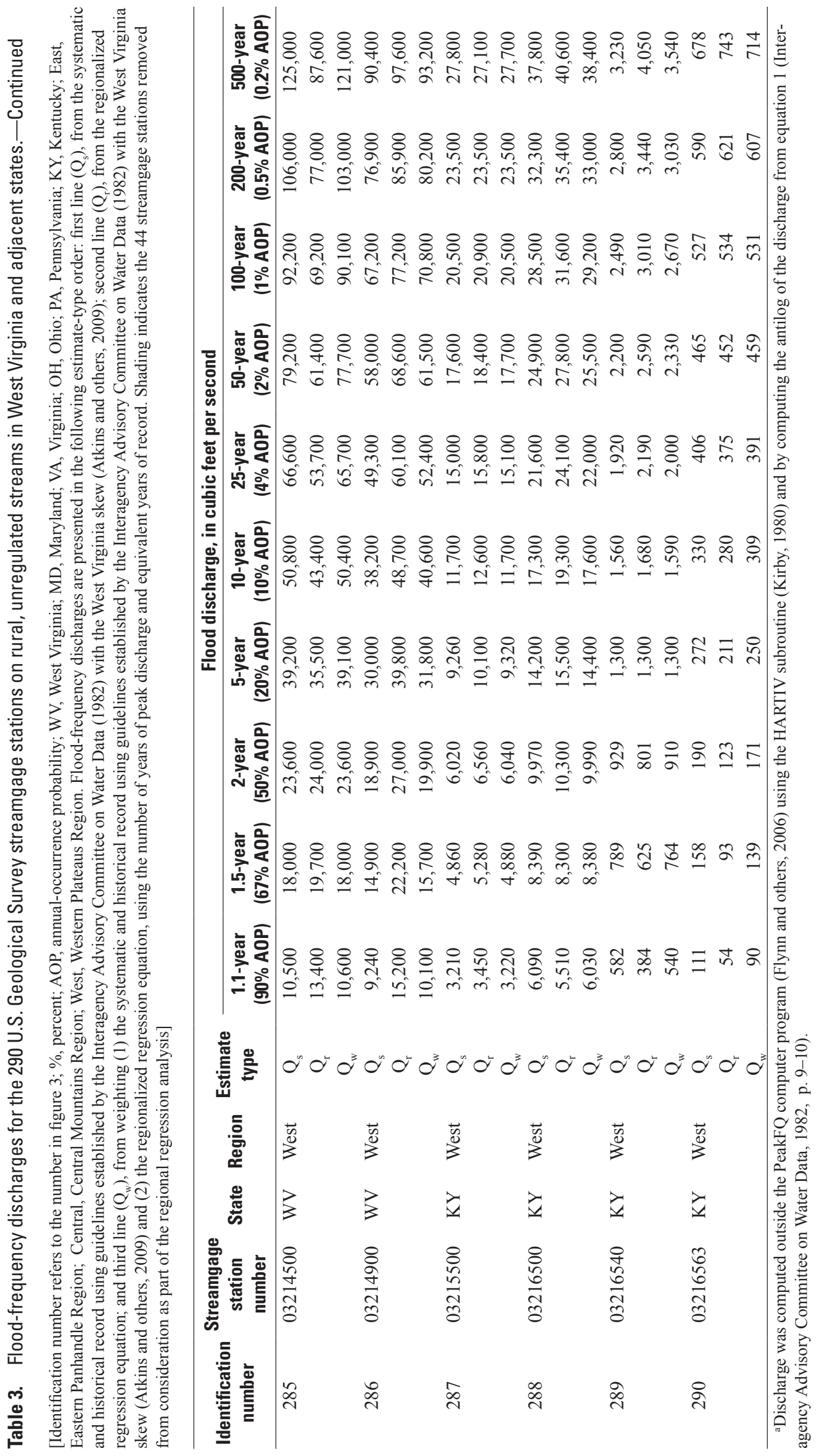




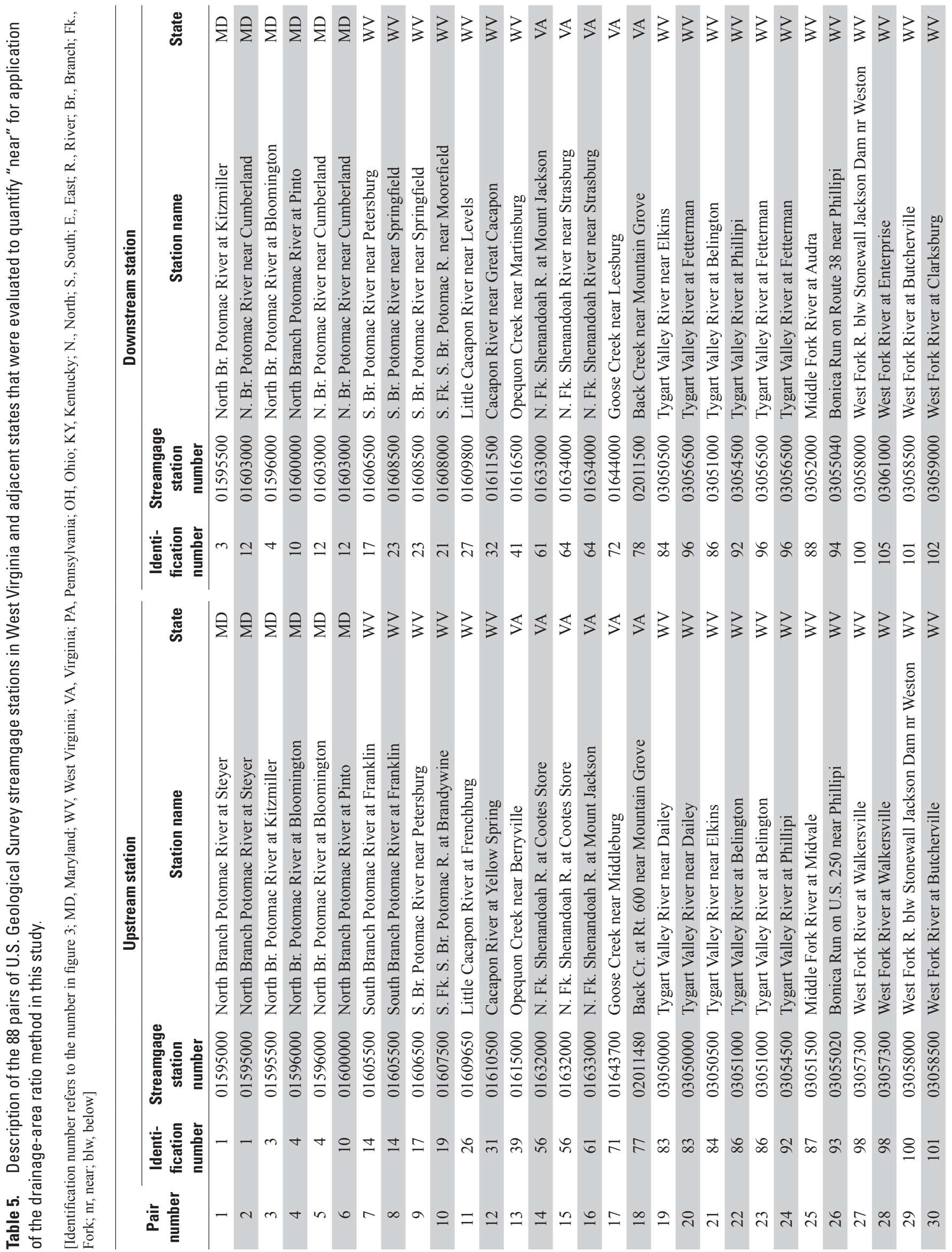




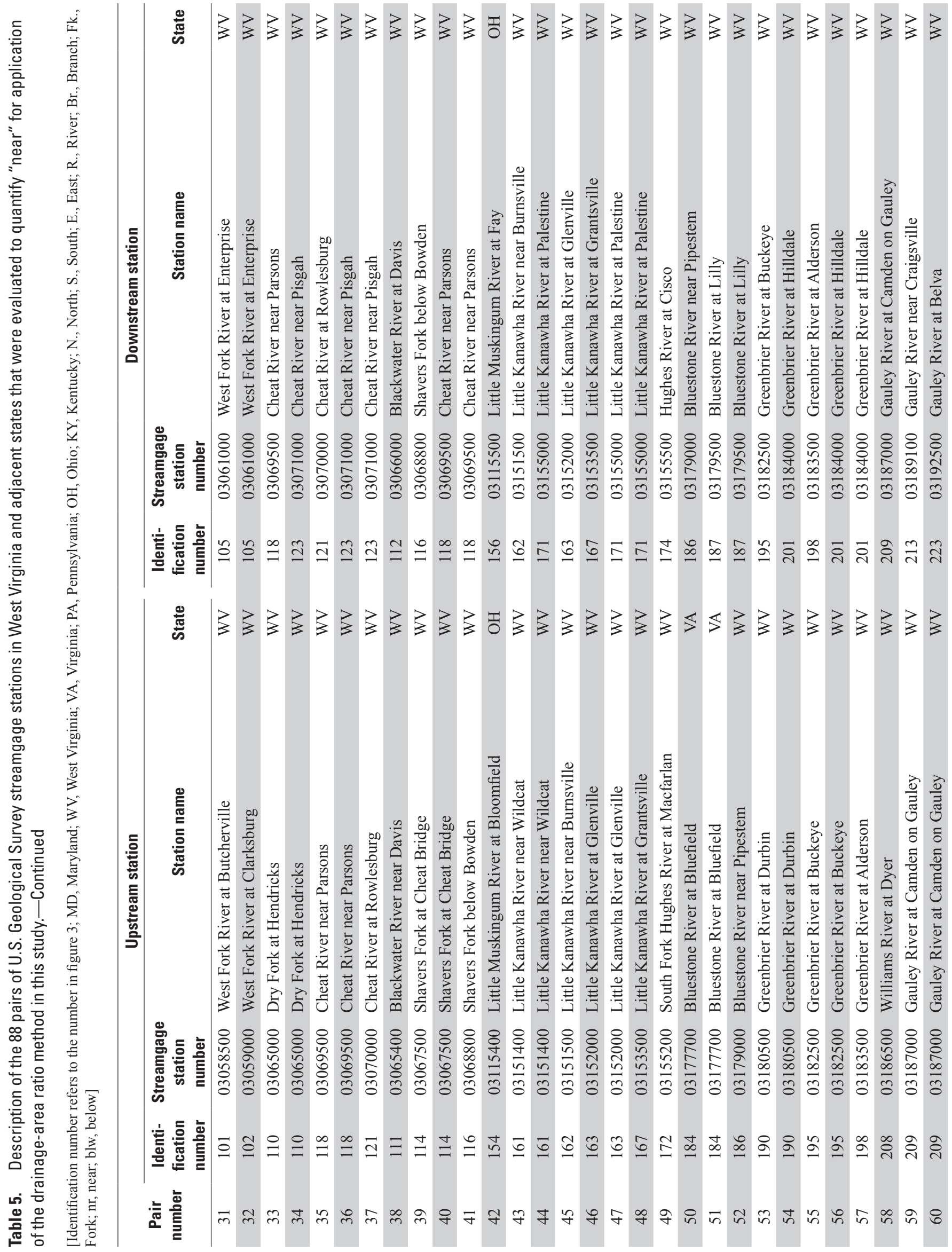




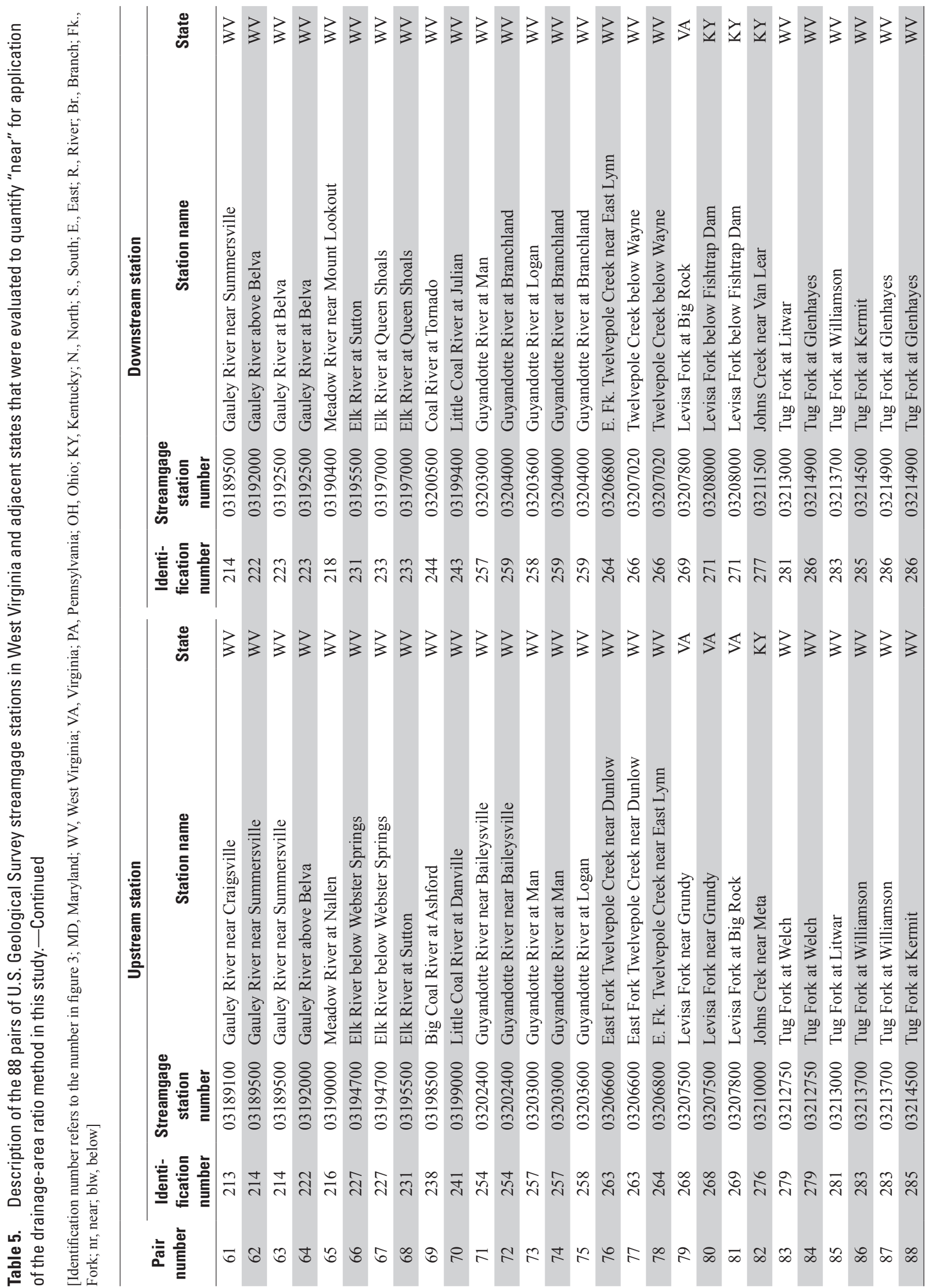


(This page intentionally left blank.) 
Appendix 1 


\section{Appendix 1. Matrices Used to Compute Individual Standard Errors of Prediction}

[PK(n_n), peak discharge for the (n.n)-year recurrence interval; PK(n), peak discharge for the (n)-year recurrence interval; \%, percent; AOP, annual-occurrence probability; $\gamma^{2}$, standard error of the model squared; numbers are given in scientific notation where $0.32483 \mathrm{E}-01$ is 0.032483 ]

\section{Eastern Panhandle Region \\ $\begin{array}{cr}\text { PK1_1(90\%AOP) } & \gamma^{2}=0.32483 \mathrm{E}-01 \\ 0.36765 \mathrm{E}-02 & -0.13943 \mathrm{E}-02 \\ -0.13943 \mathrm{E}-02 & 0.79153 \mathrm{E}-03\end{array}$}

PK1_5(67\%AOP) $\gamma^{2}=0.22559 \mathrm{E}-01$

$0.26813 \mathrm{E}-02 \quad-0.98579 \mathrm{E}-03$

$-0.98579 \mathrm{E}-03 \quad 0.55605 \mathrm{E}-03$
PK2(50\%AOP) $\gamma^{2}=0.18489 \mathrm{E}-01$
$0.24610 \mathrm{E}-02 \quad-0.86628 \mathrm{E}-03$
$-0.86628 \mathrm{E}-03 \quad 0.48293 \mathrm{E}-03$
PK5(20\%AOP) $\gamma^{2}=0.11967 \mathrm{E}-01$
$0.24958 \mathrm{E}-02 \quad-0.76020 \mathrm{E}-03$
$-0.76020 \mathrm{E}-03 \quad 0.41065 \mathrm{E}-03$
PK10(10\%AOP) $\gamma^{2}=0.92526 \mathrm{E}-02$
$0.27016 \mathrm{E}-02 \quad-0.75370 \mathrm{E}-03$
$-0.75370 \mathrm{E}-03 \quad 0.40192 \mathrm{E}-03$

$\begin{array}{cr}\text { PK25(4\%AOP) } \gamma^{2}=0.71876 \mathrm{E}-02 \\ 0.30780 \mathrm{E}-02 & -0.79872 \mathrm{E}-03 \\ -0.79872 \mathrm{E}-03 & 0.42199 \mathrm{E}-03\end{array}$
PK50(2\%AOP) $\gamma^{2}=0.64308 \mathrm{E}-02$
$0.34417 \mathrm{E}-02 \quad-0.86987 \mathrm{E}-03$
$-0.86987 \mathrm{E}-03 \quad 0.45750 \mathrm{E}-03$
PK100(1\%AOP) $\gamma^{2}=0.61728 \mathrm{E}-02$
$0.38754 \mathrm{E}-02 \quad-0.96990 \mathrm{E}-03$
$-0.96990 \mathrm{E}-03 \quad 0.50843 \mathrm{E}-03$

$\begin{array}{cc}\text { PK200(0.5\%AOP) } & \gamma^{2}=0.63080 \mathrm{E}-02 \\ 0.43778 \mathrm{E}-02 & -0.10963 \mathrm{E}-02 \\ -0.10963 \mathrm{E}-02 & 0.57352 \mathrm{E}-03\end{array}$

$\begin{array}{cc}\text { PK500(0.2\%AOP) } & \gamma^{2}=0.69967 \mathrm{E}-02 \\ 0.51444 \mathrm{E}-02 & -0.13012 \mathrm{E}-02 \\ -0.13012 \mathrm{E}-02 & 0.68008 \mathrm{E}-03\end{array}$

\section{Central Mountains Region \\ $\begin{array}{cr}\text { PK1_1(90\%AOP) } & \gamma^{2}=0.27978 \mathrm{E}-01 \\ 0.26613 \mathrm{E}-02 & -0.98361 \mathrm{E}-03 \\ -0.98361 \mathrm{E}-03 & 0.47958 \mathrm{E}-03\end{array}$}
PK1_5(67\%AOP) $\gamma^{2}=0.21308 \mathrm{E}-01$ $0.20667 \mathrm{E}-02 \quad-0.75807 \mathrm{E}-03$
$-0.75807 \mathrm{E}-03 \quad 0.36705 \mathrm{E}-03$
PK2(50\%AOP) $\gamma^{2}=0.19922 \mathrm{E}-01$
$0.20406 \mathrm{E}-02 \quad-0.74156 \mathrm{E}-03$
$-0.74156 \mathrm{E}-03 \quad 0.35478 \mathrm{E}-03$
PK5(20\%AOP) $\gamma^{2}=0.20745 \mathrm{E}-01$
$0.24841 \mathrm{E}-02 \quad-0.88266 \mathrm{E}-03$
$-0.88266 \mathrm{E}-03 \quad 0.41029 \mathrm{E}-03$
PK10(10\%AOP) $\gamma^{2}=0.23263 \mathrm{E}-01$
$0.29889 \mathrm{E}-02 \quad-0.10523 \mathrm{E}-02$
$-0.10523 \mathrm{E}-02 \quad 0.48398 \mathrm{E}-03$
PK25(4\%AOP) $\gamma^{2}=0.27815 \mathrm{E}-01$
$0.37621 \mathrm{E}-02 \quad-0.13163 \mathrm{E}-02$
$-0.13163 \mathrm{E}-02 \quad 0.60165 \mathrm{E}-03$
PK50(2\%AOP) $\gamma^{2}=0.31932 \mathrm{E}-01$
$0.44057 \mathrm{E}-02 \quad-0.15382 \mathrm{E}-02$
$-0.15382 \mathrm{E}-02 \quad 0.70196 \mathrm{E}-03$
PK100(1\%AOP) $\gamma^{2}=0.36527 \mathrm{E}-01$
$0.50907 \mathrm{E}-02 \quad-0.17758 \mathrm{E}-02$
$-0.17758 \mathrm{E}-02 \quad 0.81032 \mathrm{E}-03$

$\begin{array}{cc}\text { PK200(0.5\%AOP) } & \gamma^{2}=0.41553 \mathrm{E}-01 \\ 0.58123 \mathrm{E}-02 & -0.20274 \mathrm{E}-02 \\ -0.20274 \mathrm{E}-02 & 0.92586 \mathrm{E}-03\end{array}$

PK500(0.2\%AOP) $\gamma^{2}=0.48810 \mathrm{E}-01$

$0.68170 \mathrm{E}-02 \quad-0.23795 \mathrm{E}-02$

$-0.23795 \mathrm{E}-02 \quad 0.10887 \mathrm{E}-02$

\section{Western Plateaus Region}

$\begin{array}{cr}\text { PK1_1(90\%AOP) } & \gamma^{2}=0.25715 \mathrm{E}-01 \\ 0.21782 \mathrm{E}-02 & -0.77332 \mathrm{E}-03 \\ -0.77332 \mathrm{E}-03 & 0.38325 \mathrm{E}-03\end{array}$

PK1 5(67\%AOP) $\gamma^{2}=0.19963 \mathrm{E}-01$ $0.16074 \mathrm{E}-02 \quad-0.56593 \mathrm{E}-03$

$-0.56593 \mathrm{E}-03 \quad 0.28053 \mathrm{E}-03$

$\begin{array}{cc}\text { PK2(50\%AOP) } \gamma^{2}=0.17940 \mathrm{E}-01 \\ 0.14888 \mathrm{E}-02 & -0.51918 \mathrm{E}-03 \\ -0.51918 \mathrm{E}-03 & 0.25507 \mathrm{E}-03\end{array}$

PK5(20\%AOP) $\gamma^{2}=0.15490 \mathrm{E}-01$

$0.15374 \mathrm{E}-02 \quad-0.52302 \mathrm{E}-03$

$-0.52302 \mathrm{E}-03 \quad 0.24868 \mathrm{E}-03$

$\begin{array}{cc}\text { PK10(10\%AOP) } & \gamma^{2}=0.15120 \mathrm{E}-01 \\ 0.17035 \mathrm{E}-02 & -0.57249 \mathrm{E}-03 \\ -0.57249 \mathrm{E}-03 & 0.26724 \mathrm{E}-03\end{array}$

PK25(4\%AOP) $\gamma^{2}=0.15624 \mathrm{E}-01$

$0.19906 \mathrm{E}-02 \quad-0.66264 \mathrm{E}-03$

$-0.66264 \mathrm{E}-03 \quad 0.30467 \mathrm{E}-03$

PK50(2\%AOP) $\gamma^{2}=0.16517 \mathrm{E}-01$

$0.22400 \mathrm{E}-02 \quad-0.74298 \mathrm{E}-03$

$-0.74298 \mathrm{E}-03 \quad 0.33935 \mathrm{E}-03$

$\begin{array}{cc}\text { PK100(1\%AOP) } & \gamma^{2}=0.17743 \mathrm{E}-01 \\ 0.25100 \mathrm{E}-02 & -0.83124 \mathrm{E}-03 \\ -0.83124 \mathrm{E}-03 & 0.37818 \mathrm{E}-03\end{array}$

PK200(0.5\%AOP) $\gamma^{2}=0.19246 \mathrm{E}-01$

$0.27968 \mathrm{E}-02 \quad-0.92609 \mathrm{E}-03$

$-0.92609 \mathrm{E}-03 \quad 0.42049 \mathrm{E}-03$

PK500(0.2\%AOP) $\gamma^{2}=0.21600 \mathrm{E}-01$

$0.31977 \mathrm{E}-02 \quad-0.10601 \mathrm{E}-02$

$-0.10601 \mathrm{E}-02 \quad 0.48102 \mathrm{E}-03$ 
For additional information, write to:

Director

U.S. Geological Survey

West Virginia Water Science Center

11 Dunbar Street

Charleston, WV 25301

or visit our Web site at:

http://wv.usgs.gov/

Document prepared by the West Trenton Publishing Service Center 
